\title{
STYX RIVER ELECTROMAGNETIC AND MAGNETIC AIRBORNE GEOPHYSICAL SURVEY DATA COMPILATION
}

Burns, L.E., Emond, A.M., Fugro Airborne Surveys Corp., and Stevens Exploration Management Corp

Geophysical Report 2019-2

2019

STATE OF ALASKA

DEPARTMENT OF NATURAL RESOURCES

DIVISION OF GEOLOGICAL \& GEOPHYSICAL SURVEYS
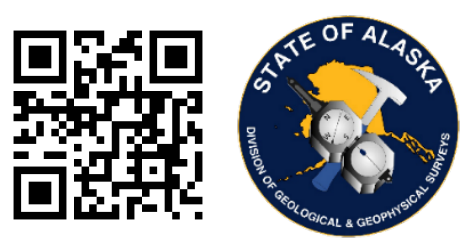
STATE OF ALASKA

Michael J. Dunleavy, Governor

DEPARTMENT OF NATURAL RESOURCES

Corri A. Feige, Commissioner

\title{
DIVISION OF GEOLOGICAL \& GEOPHYSICAL SURVEYS
}

Steve Masterman, State Geologist \& Director

Publications produced by the Division of Geological \& Geophysical Surveys are available to download from the DGGS website (dggs.alaska.gov). Publications on hard-copy or digital media can be examined or purchased in the Fairbanks office:

\author{
Alaska Division of Geological \& Geophysical Surveys (DGGS) \\ 3354 College Road | Fairbanks, Alaska 99709-3707 \\ Phone: 907.451.5010 | Fax 907.451.5050 \\ dggspubs@alaska.gov $\mid$ dggs.alaska.gov
}

DGGS publications are also available at:

Alaska State Library, Historical

Collections \& Talking Book Center

395 Whittier Street

Juneau, Alaska 99801

Alaska Resource Library and

Information Services (ARLIS)

3150 C Street, Suite 100

Anchorage, Alaska 99503

\section{Suggested citation:}

Burns, L.E., Emond, A.M., Fugro Airborne Surveys Corp., and Stevens Exploration Management Corp, 2019, Styx River electromagnetic and magnetic airborne geophysical survey data compilation: Alaska Division of Geological \& Geophysical Surveys Geophysical Report 2019-2. http://doi.org/10.14509/30166
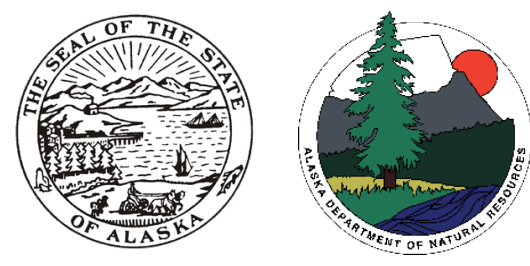


\title{
STYX RIVER ELECTROMAGNETIC AND MAGNETIC AIRBORNE GEOPHYSICAL SURVEY DATA COMPILATION \\ Burns, L.E., ${ }^{1}$ Emond, A.M. ', Fugro Airborne Surveys Corp., and Stevens Exploration Management Corp
}

\begin{abstract}
This geophysical survey is located in the upper South Fork Kuskokwim River and Skwentna river drainages, southcentral Alaska. The Styx River survey is in the Yentna and McGrath mining districts, about 150 kilometers northwest of Anchorage, Alaska. Frequency domain electromagnetic and magnetic data were collected with the DIGHEM system from October 16th to November 12th, 2007 and from March 21st to April 22nd, 2008. A total of 5338.6 line-kilometers were collected covering 1859.3 square kilometers. Line spacing was 400 meters $(\mathrm{m})$. Data were collected $30 \mathrm{~m}$ above the ground surface from a helicopter towed sensor platform ("bird") on a $30 \mathrm{~m}$ long line.
\end{abstract}

\section{PURPOSE}

This airborne geophysical survey is part of a program to acquire data on Alaska's most promising mineral belts and districts. The information acquired is aimed at catalyzing new private sector exploration, discovery, and ultimate development and production. The purpose of the survey was to map the magnetic and conductive properties of the survey area. Major lode-mineral prospects in the survey area include Estelle, Whistler, Terra, and Copper Joe. Other gold and base-metal anomalies, altered zones, favorable lithologies, and structural zones are known to exist throughout the survey area.

\section{SURVEY OVERVIEW DESCRIPTION}

This document provides an overview of the survey and includes text and figures of select primary and derivative products of this survey. A table of digital data packages available for download is provided to assist users in data selection. For reference, a catalog of the available maps is presented in reduced resolution. Please consult the metadata, project report, and digital data packages for more information and data.

\section{ACKNOWLEDGMENTS}

Funding was provided by the Alaska State Legislature as part of the DGGS Airborne Geophysical/Geological Mineral Inventory (AGGMI) program and by a contribution from Anglo American Exploration (USA) Inc.

\footnotetext{
${ }^{1}$ Alaska Division of Geological \& Geophysical Surveys, 3354 College Road, Fairbanks, Alaska 99709-3707
} 


\begin{tabular}{|c|c|c|}
\hline Data Type & Provider & Description \\
\hline ascii_data & contractor & ASCII format line data, other ASCII data \\
\hline databases_geosoft & contractor & $\begin{array}{l}\text { Geosoft format database of final line data, other } \\
\text { Geosoft format databases }\end{array}$ \\
\hline documents & contractor and DGGS & $\begin{array}{l}\text { Project and field reports, survey background } \\
\text { information, gridded data explanations, other } \\
\text { documentation }\end{array}$ \\
\hline grids_ermapper & contractor & $\begin{array}{l}\text { Geographically registered gridded data, ER Mapper } \\
\text { ERS format }\end{array}$ \\
\hline grids_geosoft & contractor and DGGS & $\begin{array}{l}\text { Geosoft-format binary grids, these grids can be } \\
\text { viewed in ESRI ArcMap using a free plugin from } \\
\text { Geosoft or a free viewer available from Geosoft }\end{array}$ \\
\hline images_registered & DGGS & GeoTiff format images of all gridded data \\
\hline $\mathrm{kmz}$ & contractor & $\begin{array}{l}\text { keyhole markup language }(\mathrm{kml}) \mathrm{kmz} \text { archive files of } \\
\text { project data. Viewable in Google Earth and other } \\
\text { compatible programs }\end{array}$ \\
\hline maps_pdf_format & contractor & Printable maps in pdf format \\
\hline maps_prn_format & contractor & $\begin{array}{l}\text { Printable maps in HPGL/G printer file format with } \\
\text { extension .prn }\end{array}$ \\
\hline profiles_stacked & contractor & $\begin{array}{l}\text { Distance-based profiles of the digitally recorded } \\
\text { geophysical data are generated and plotted at an } \\
\text { appropriate scale. The profiles display } \\
\text { electromagnetic anomalies with their respective } \\
\text { interpretive symbols. Printable in pdf format. }\end{array}$ \\
\hline vector_data & contractor and DGGS & $\begin{array}{l}\text { Line path, data contours, and survey boundary in } \\
\text { ESRI shapefile (SHP) format, ESRI Geodatabase } \\
\text { format, and/or AutoCAD dxf format }\end{array}$ \\
\hline video_flightpath & contractor & Survey flight path downward facing video \\
\hline
\end{tabular}




\section{REFERENCES}

Akima, H., 1970, A new method of interpolation and smooth curve fitting based on local procedures: Journal of the Association of Computing Machinery, v. 17, n. 4, p. 589-602.

Burns, L.E., CGG, and Fugro GeoServices, Inc., 2014, East Styx survey area: Airborne magnetic, electromagnetic and radiometric data in line (point), grid, vector, and map formats, Talkeetna, Tyonek, McGrath, and Lime Hills quadrangles, south-central Alaska: Alaska Division of Geological \& Geophysical Surveys Geophysical Report 2014-5, scale 1:63,360, 1 DVD. http://doi.org/10.14509/29142

Burns, L.E., CGG, and Fugro GeoServices, Inc., 2014, Farewell survey area: Airborne magnetic, electromagnetic and radiometric data in line (point), grid, vector, and map formats, McGrath and Lime Hills quadrangles, south-central Alaska: Alaska Division of Geological \& Geophysical Surveys Geophysical Report 2014-2, scale 1:63,360, 1 DVD. http://doi.org/10.14509/27291

Burns, L.E., Fugro Airborne Surveys Corp., Stevens Exploration Management Corp., and Anglo American Exploration (USA), Inc., 2008, Preliminary final version of part of the airborne geophysical data from the Styx River Survey, southcentral Alaska: parts of Lime Hills and Tyonek quadrangles: Alaska Division of Geological \& Geophysical Surveys Geophysical Report 2008-2, 5 sheets, scale 1:63,360. http://doi.org/10.14509/15981

Burns, L.E., Fugro Airborne Surveys Corp., and Fugro GeoServices, Inc., 2013, Dalzell Creek survey area: Airborne magnetic, electromagnetic, and radiometric data in line (point), grid, vector, and map formats, McGrath Quadrangle, southcentral Alaska: Alaska Division of Geological \& Geophysical Surveys Geophysical Report 2013-3. http://doi.org/10.14509/25439

Burns, L.E., Fugro Airborne Surveys Corp., and Fugro GeoServices, Inc., 2013, Middle Styx survey area: Airborne magnetic, electromagnetic, and radiometric data in line (point), grid, vector, and map formats, Lime Hills and Tyonek quadrangles, southcentral Alaska: Alaska Division of Geological \& Geophysical Surveys Geophysical Report 2013-2, scale 1:63,360, 1 DVD. http://doi.org/10.14509/25419

Burns, L.E., Fugro Airborne Surveys Corp., and Stevens Exploration Management Corp., 2008, Line, grid, and vector data, and plot files for the airborne geophysical survey of the Styx River Survey, southcentral Alaska: Alaska Division of Geological \& Geophysical Surveys Geophysical Report 2008-3, 27 sheets, 1 DVD. http://doi.org/10.14509/16561

CGG, and Fugro GeoServices, Inc., 2015, Farewell and Middle Styx survey areas: Project report, interpretation maps, EM anomalies, stacked multi-channel profiles, and other products of the airborne geophysical surveys, parts of the McGrath, Lime Hills, and Tyonek quadrangles, south-central Alaska: Alaska Division of Geological \& Geophysical Surveys Geophysical Report 2014-4, 22 sheets. http://doi.org/10.14509/29349

Geoterrex-Dighem, Fugro Airborne Surveys, Stevens Exploration Management Corp., Pritchard, R.A., Burns, L.E., Emond, A.M., and DGGS Staff, 2016, Sub-regional, merged, gridded airborne geophysical data: Alaska Division of Geological \& Geophysical Surveys Digital Data Series 12, 1 DVD. $\underline{\text { http://doi.org/10.14509/29555 }}$ 


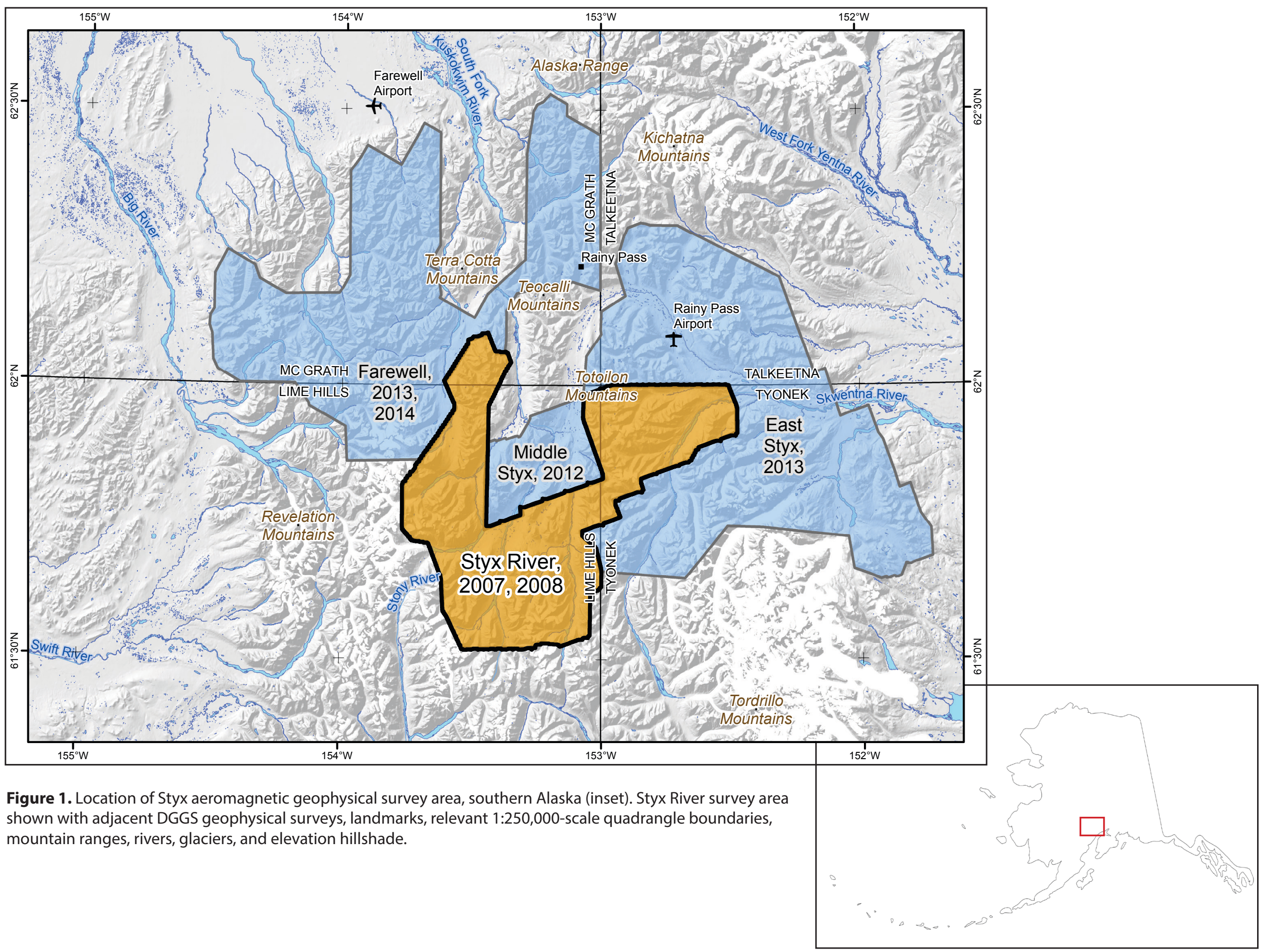




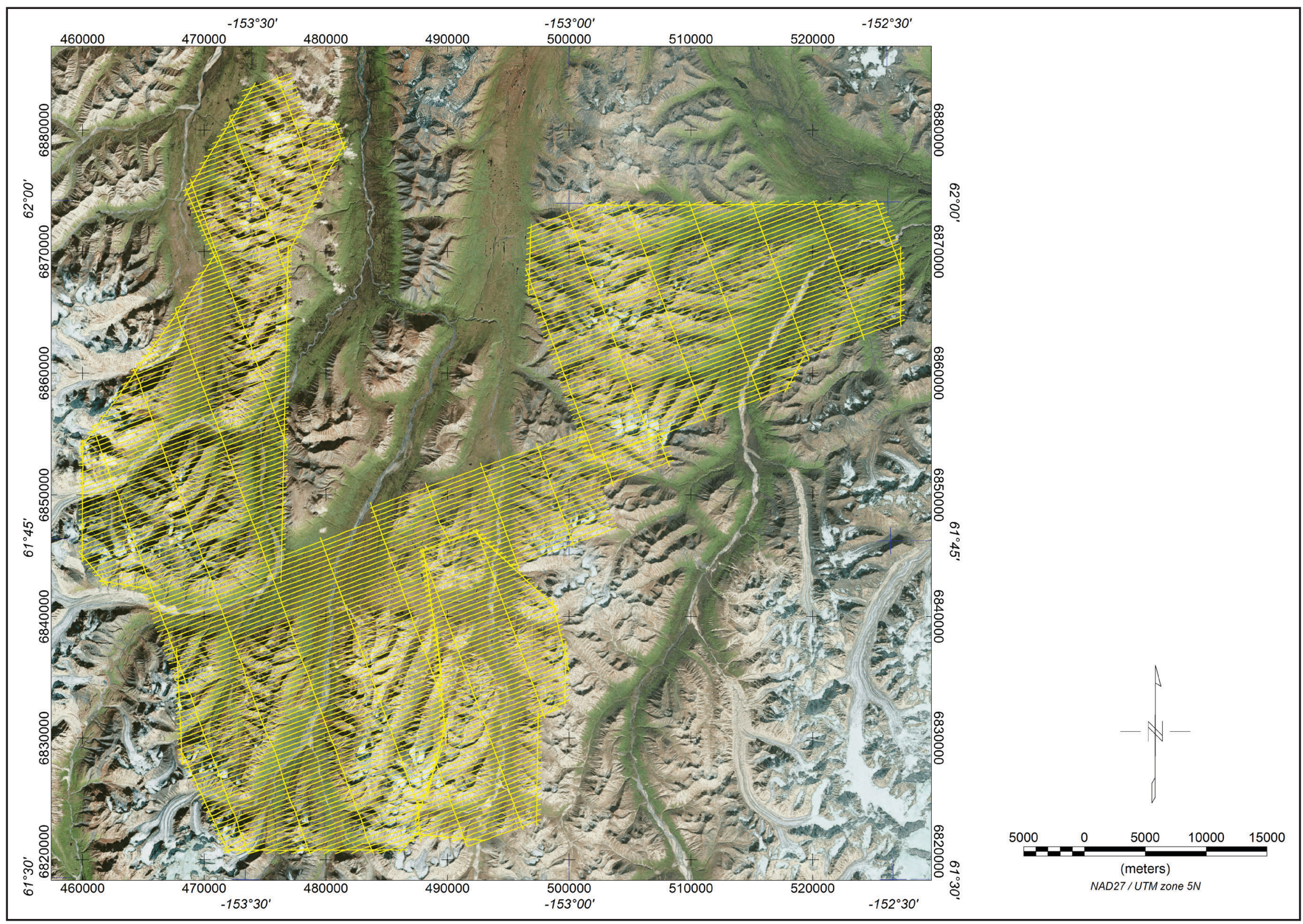

Figure 2. Flight path with orthometric image. 


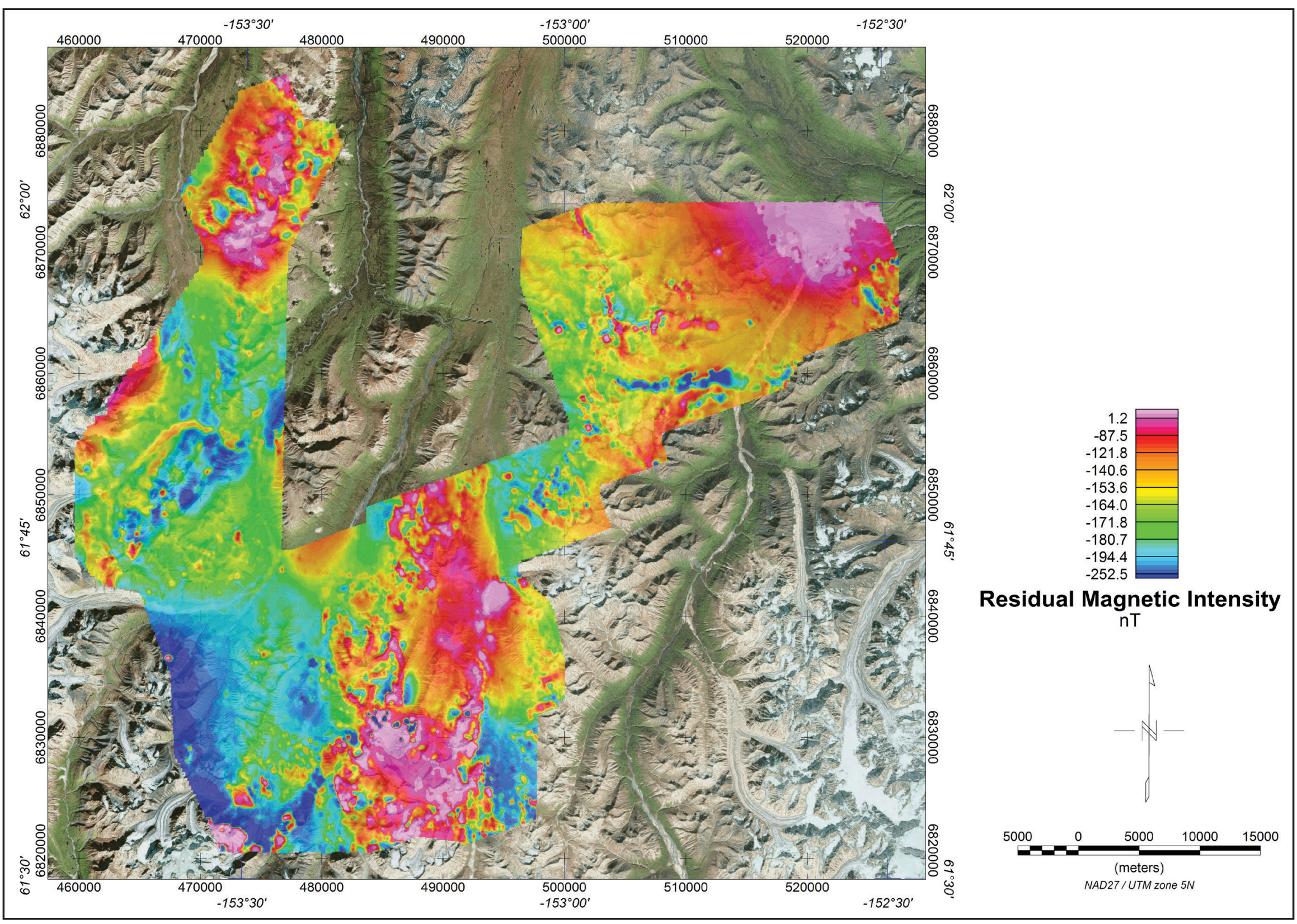

Figure 3. The residual magnetic intensity data were created using digitally recorded magnetic total field data from a Fugro D1344 magnetometer with a Scintrex CS3 cesium sensor. Data were collected at a sampling interval of 0.1 seconds. The magnetic data were (1) corrected for diurnal variations by subtracting the digitally recorded base station magnetic data, (2) IGRF corrected (IGRF model 2005), updated for date of flight and altimeter variations), (3) leveled to the tie line data, and (4) interpolated onto a regular 80 m grid using minimum curvature. 


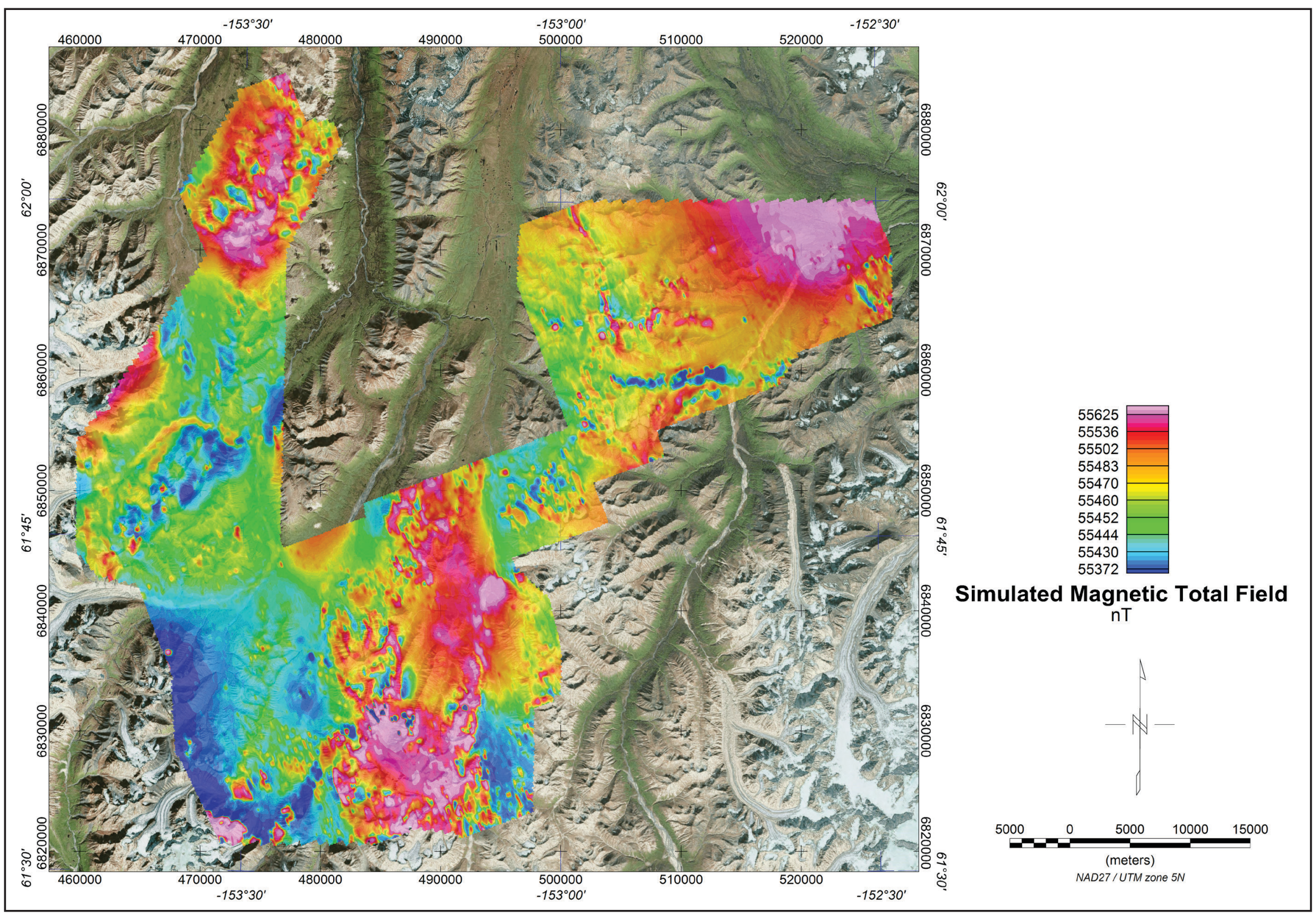

Figure 4. The simulated magnetic total field data were created using digitally recorded magnetic total field data from a Fugro D1344 magnetometer with a Scintrex CS3 cesium sensor. Data were collected at a sampling interval of 0.1 seconds. The magnetic data were (1) corrected for diurnal variations by subtracting the digitally recorded base station magnetic data, (2) IGRF corrected (IGRF model 2005), updated for date of flight and altimeter variations), (3) leveled to the tie line data, (4) a constant value of approximately $55,000 \mathrm{nT}$ was added to all data, and (5) interpolated onto a regular $80 \mathrm{~m}$ grid using a modified Akima (Akima 1970) technique. 


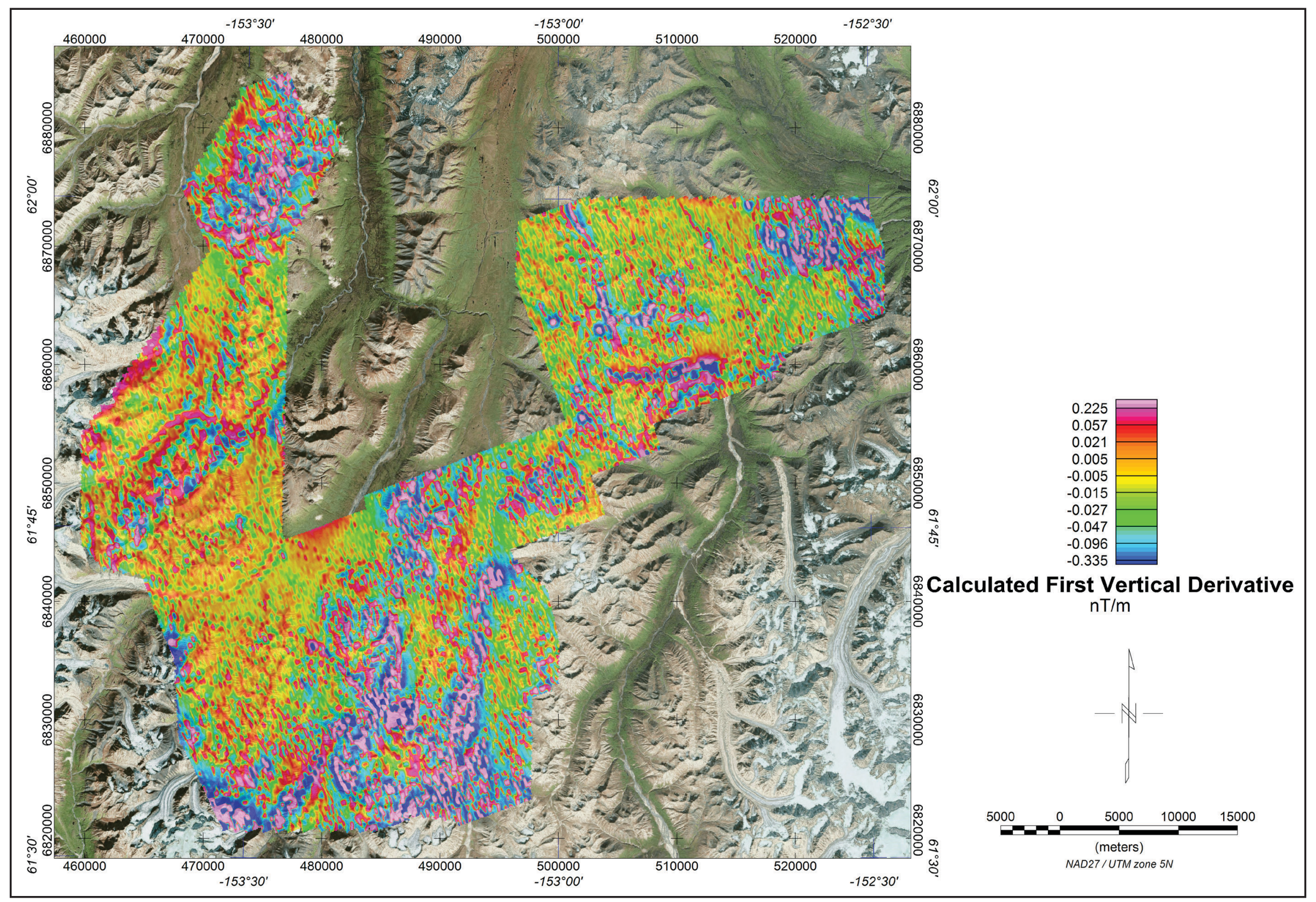

Figure 5. The calculated first vertical derivative data were created using digitally recorded data from a Fugro D1344 cesium magnetometer with a Scintrex CS3 sensor. Data were collected at a sampling interval of 0.1 seconds. The magnetic data were (1) corrected for diurnal variations by subtraction of the digitally recorded base station magnetic data, (2) IGRF corrected (IGRF model 2005, updated for date of flight and altimeter variations), (3) leveled to the tie line data, and (4) interpolated onto a regular $80 \mathrm{~m}$ grid using a modified Akima (1970) technique. The first vertical derivative grid was calculated from the processed total magnetic field grid using a FFT base frequency domain filtering algorithm. The resulting first vertical derivative grid provides better definition and resolution of near- surface magnetic units and helps to identify weak magnetic features that may not be evident on the total field data. 


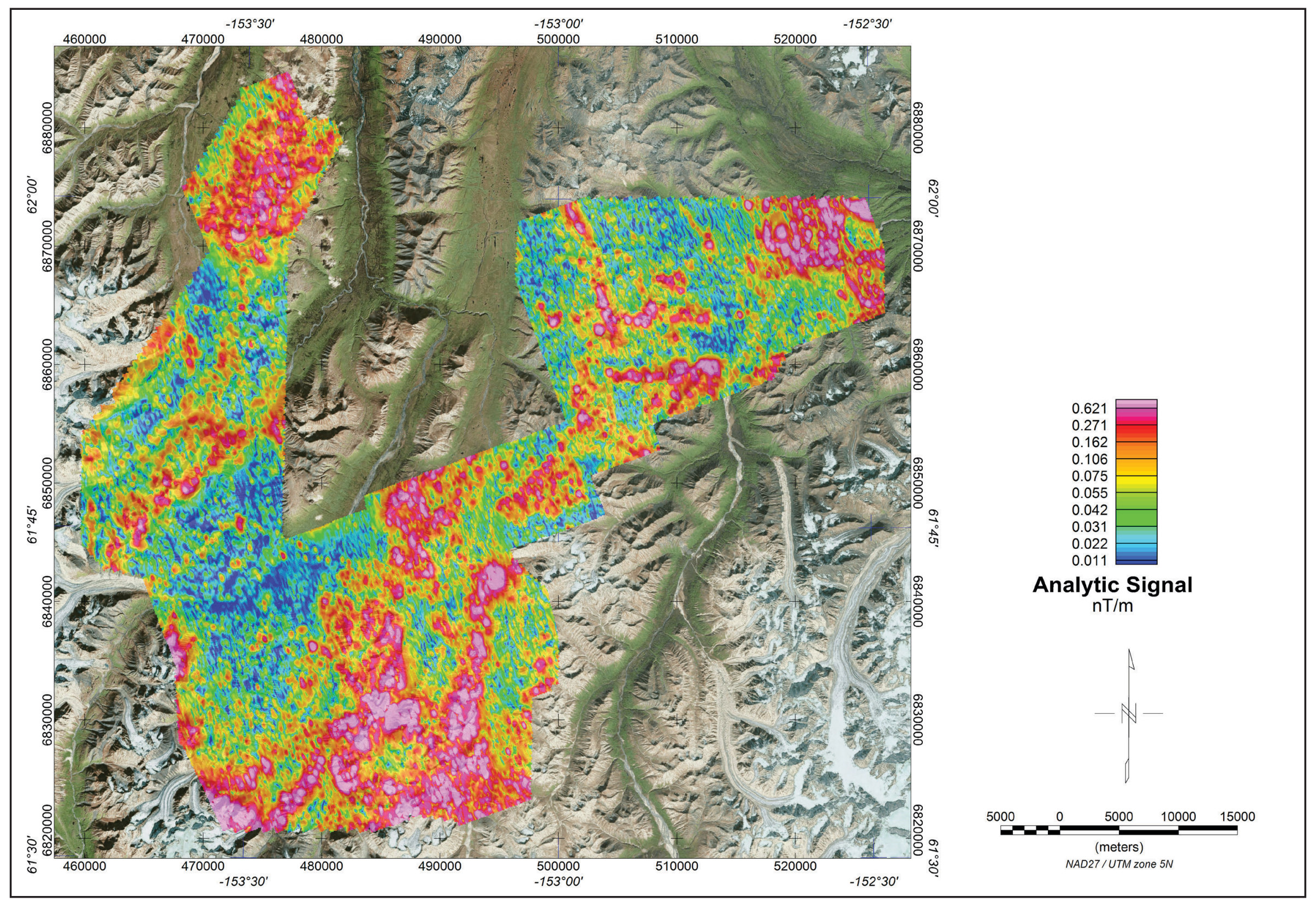

Figure 6. Analytic signal is the total amplitude of all directions of magnetic gradient calculated from the sum of the squares of the three orthogonal gradients. Mapped highs in the calculated analytic signal of magnetic parameter locate the anomalous source body edges and corners (such as contacts, fault/shear zones, etc.). Analytic signal maxima are located directly over faults and contacts, regardless of structural dip, and independent of the direction of the induced and/or remanent magnetizations. 


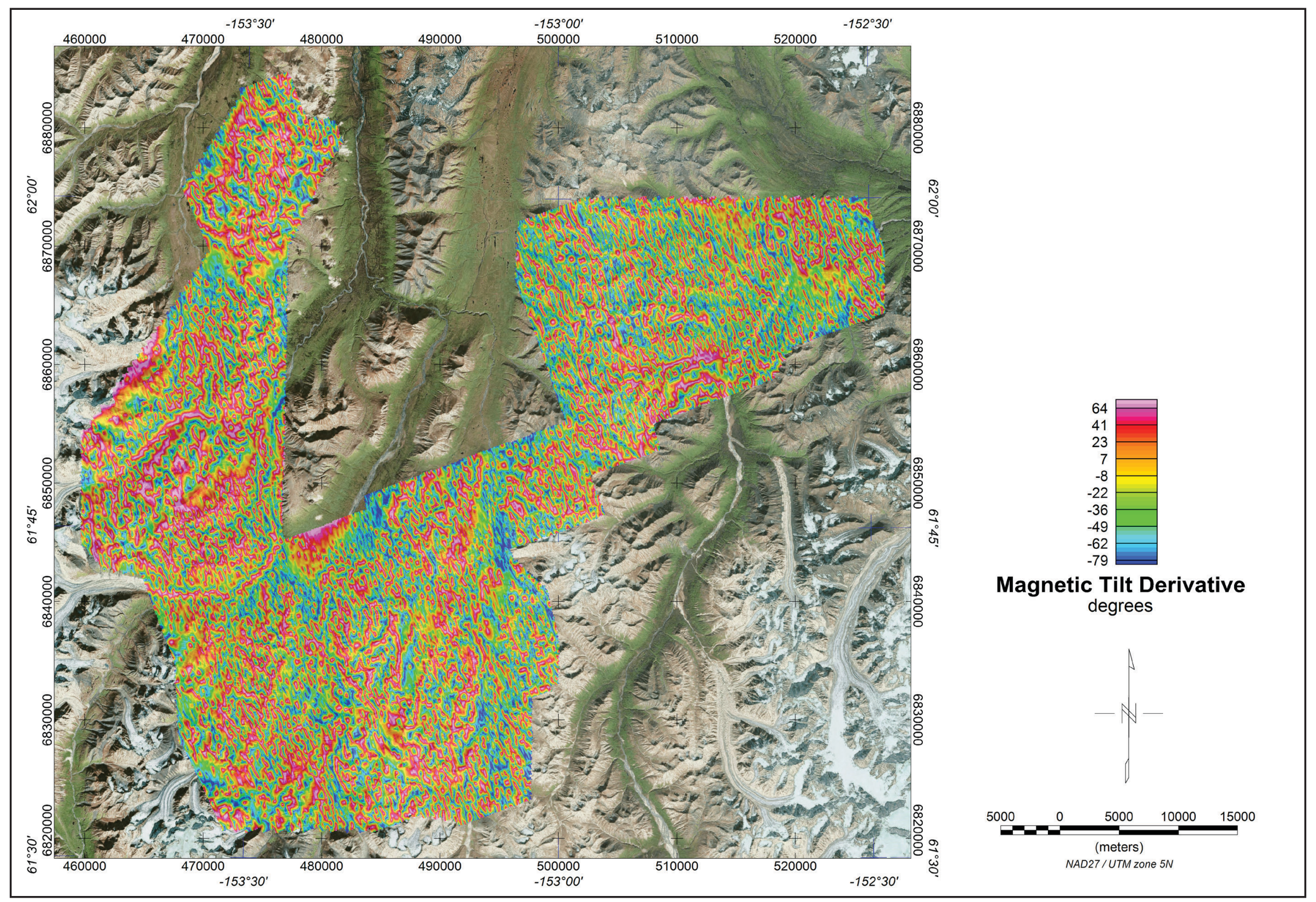

Figure 7. The tilt derivative is the angle between the horizontal gradient and the total gradient, which can be used to identify the depth and type of source. The tilt angle is positive over the source, crosses through zero at, or near, the edge of a vertical-sided source, and is negative outside the source region. The tilt derivative has the added advantage of responding equally well to shallow and deep sources and is able to resolve deeper sources that may be masked by larger responses from shallower sources. 


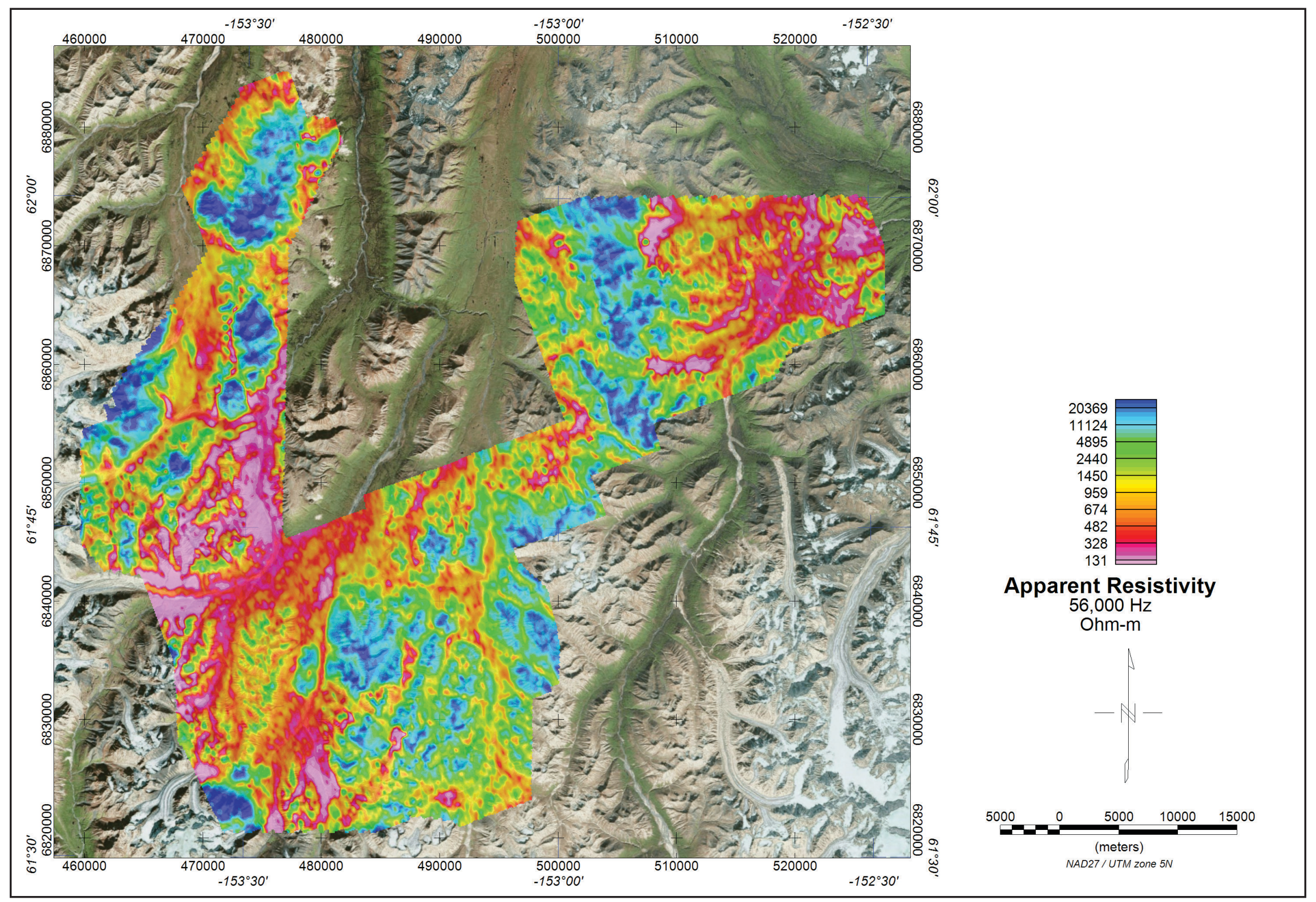

Figure 8. The DIGHEM ${ }^{\vee}$ EM system measured inphase and quadrature components at five frequencies. Two vertical coaxial coil-pairs operated at 1,000 and $5500 \mathrm{~Hz}$ while three horizontal coplanar coil-pairs operated at $900,7,200$ and $56,000 \mathrm{~Hz}$. EM data were sampled at 0.1 second intervals. The EM system responds to bedrock conductors, conductive overburden, and cultural sources. Apparent resistivity is generated from the inphase and quadrature component of the coplanar $56,000 \mathrm{~Hz}$ using the pseudo-layer half space model. The data were interpolated onto a regular $80 \mathrm{~m}$ grid using a modified Akima (Akima 1970) technique. 


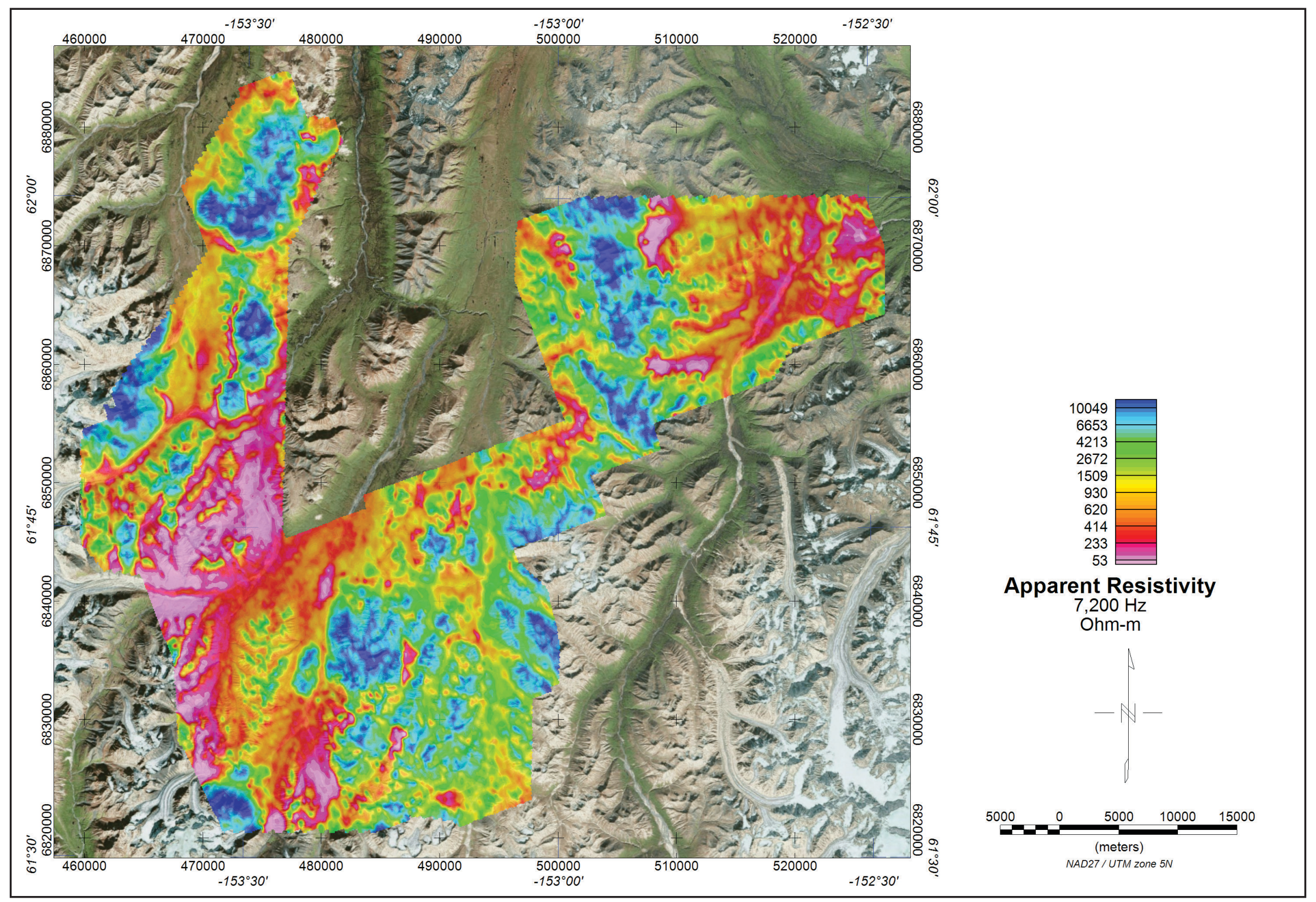

Figure 9. The DIGHEMV EM system measured inphase and quadrature components at five frequencies. Two vertical coaxial coil-pairs operated at 1,000 and $5500 \mathrm{~Hz}$ while three horizontal coplanar coil-pairs operated at $900,7,200$ and $56,000 \mathrm{~Hz}$. EM data were sampled at 0.1 second intervals. The EM system responds to bedrock conductors, conductive overburden, and cultural sources. Apparent resistivity is generated from the inphase and quadrature component of the coplanar 7,200 Hz using the pseudo-layer half space model. The data were interpolated onto a regular $80 \mathrm{~m}$ grid using a modified Akima (Akima 1970) technique. 


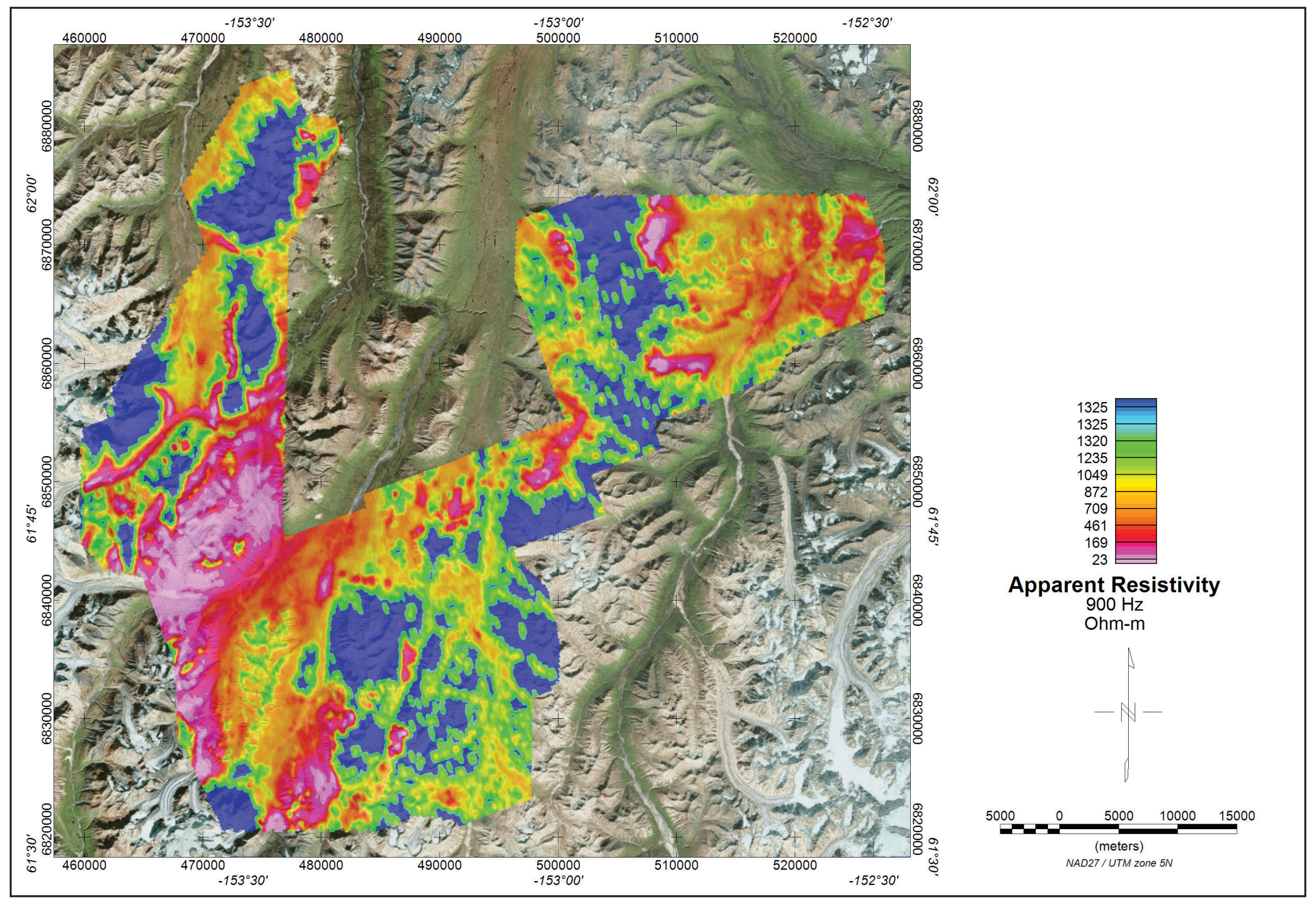

Figure 10. The DIGHEM ${ }^{\vee} E M$ system measured inphase and quadrature components at five frequencies. Two vertical coaxial coil-pairs operated at 1,000 and $5500 \mathrm{~Hz}$ while three horizontal coplanar coil-pairs operated at $900,7,200$ and $56,000 \mathrm{~Hz}$. EM data were sampled at 0.1 second intervals. The EM system responds to bedrock conductors, conductive overburden, and cultural sources. Apparent resistivity is generated from the inphase and quadrature component of the coplanar $900 \mathrm{~Hz}$ using the pseudo-layer half space model. The data were interpolated onto a regular $80 \mathrm{~m}$ grid using a modified Akima (Akima 1970) technique. 
Table 1. Copies of the following maps are included at the end of this booklet. The low-resolution, page-size maps included in this booklet are intended to be used as a search tool and are not the final product. Large-scale, full-resolution versions of each map are available to download on this publication's citation page: http://doi.org/10.14509/30166.

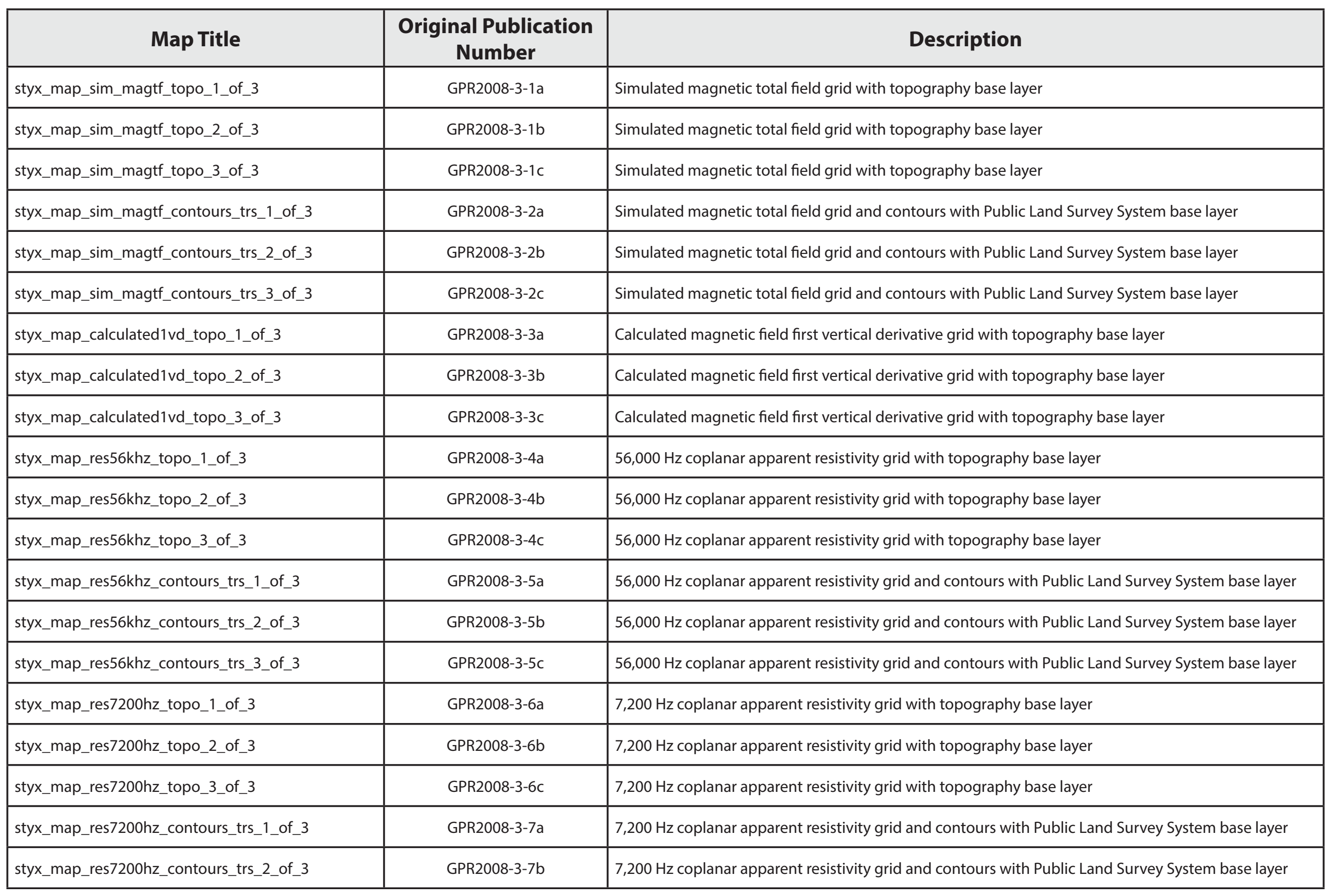


Table 1, continued. Copies of the following maps are included at the end of this booklet. The low-resolution, page-size maps included in this booklet are intended to be used as a search tool and are not the final product. Large-scale, full-resolution versions of each map are available to download on this publication's citation page: http://doi.org/10.14509/30166.

\begin{tabular}{|c|c|c|}
\hline Map Title & $\begin{array}{c}\text { Original Publication } \\
\text { Number }\end{array}$ & Description \\
\hline styx_map_res7200hz_contours_trs_3_of_3 & GPR2008-3-7c & 7,200 Hz coplanar apparent resistivity grid and contours with Public Land Survey System base layer \\
\hline styx_map_res900hz_topo_1_of_3 & GPR2008-3-8a & $900 \mathrm{~Hz}$ coplanar apparent resistivity grid with topography base layer \\
\hline styx_map_res900hz_topo_2_of_3 & GPR2008-3-8b & $900 \mathrm{~Hz}$ coplanar apparent resistivity grid with topography base layer \\
\hline styx_map_res900hz_topo_3_of_3 & GPR2008-3-8c & $900 \mathrm{~Hz}$ coplanar apparent resistivity grid with topography base layer \\
\hline styx_map_res900hz_contours_trs_1_of_3 & GPR2008-3-9a & $900 \mathrm{~Hz}$ coplanar apparent resistivity grid and contours with Public Land Survey System base layer \\
\hline styx_map_res900hz_contours_trs_2_of_3 & GPR2008-3-9b & $900 \mathrm{~Hz}$ coplanar apparent resistivity grid and contours with Public Land Survey System base layer \\
\hline styx_map_res900hz_contours_trs_3_of_3 & GPR2008-3-9c & $900 \mathrm{~Hz}$ coplanar apparent resistivity grid and contours with Public Land Survey System base layer \\
\hline styx_map_em_anomalies_sim_magtf_topo_1_of_7 & GPR2008-5-1a & electromagnetic anomalies identified by contractor, simulated magnetic total field grid, and topography \\
\hline styx_map_em_anomalies_sim_magtf_topo_2_of_7 & GPR2008-5-1b & electromagnetic anomalies identified by contractor, simulated magnetic total field grid, and topography \\
\hline styx_map_em_anomalies_sim_magtf_topo_3_of_7 & GPR2008-5-1c & electromagnetic anomalies identified by contractor, simulated magnetic total field grid, and topography \\
\hline styx_map_em_anomalies_sim_magtf_topo_4_of_7 & GPR2008-5-1d & electromagnetic anomalies identified by contractor, simulated magnetic total field grid, and topography \\
\hline styx_map_em_anomalies_sim_magtf_topo_5_of_7 & GPR2008-5-1e & electromagnetic anomalies identified by contractor, simulated magnetic total field grid, and topography \\
\hline styx_map_em_anomalies_sim_magtf_topo_6_of_7 & GPR2008-5-1f & electromagnetic anomalies identified by contractor, simulated magnetic total field grid, and topography \\
\hline styx_map_em_anomalies_sim_magtf_topo_7_of_7 & GPR2008-5-1g & electromagnetic anomalies identified by contractor, simulated magnetic total field grid, and topography \\
\hline styx_map_interpretation_1_of_3 & GPR2008-5-2a & magnetic and electromagnetic data interpretation performed by contractor \\
\hline styx_map_interpretation_2_of_3 & GPR2008-5-2b & magnetic and electromagnetic data interpretation performed by contractor \\
\hline styx_map_interpretation_3_of_3 & GPR2008-5-2c & magnetic and electromagnetic data interpretation performed by contractor \\
\hline
\end{tabular}




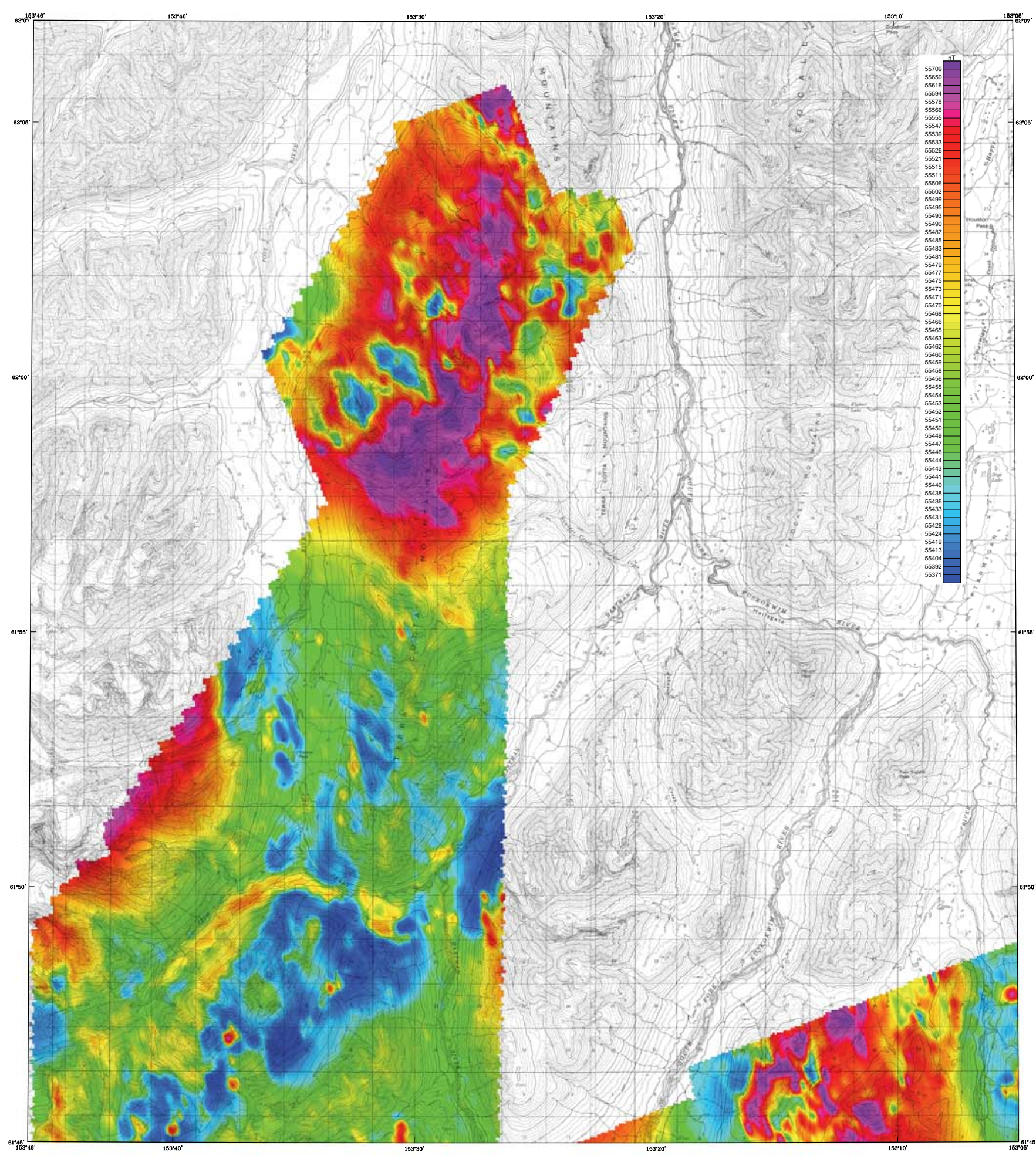

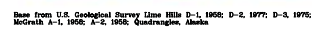
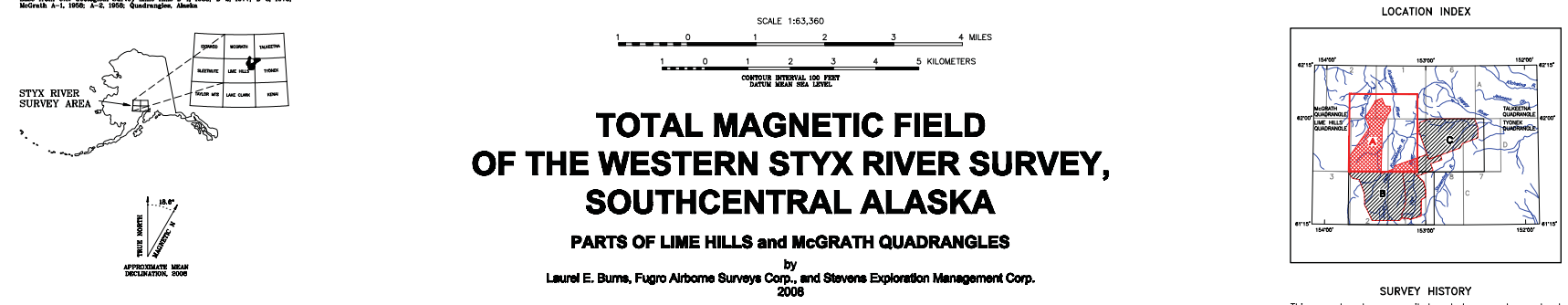


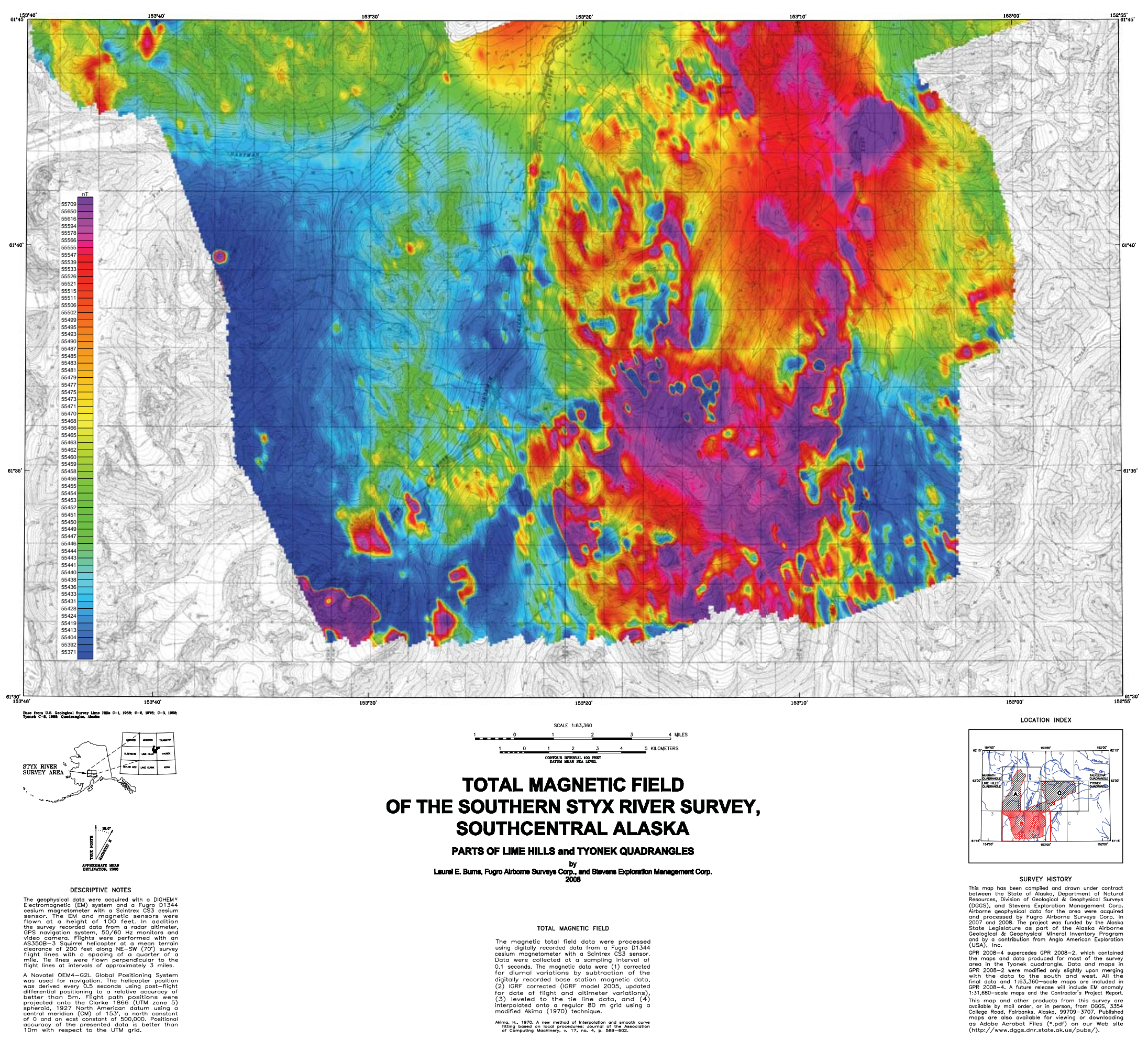




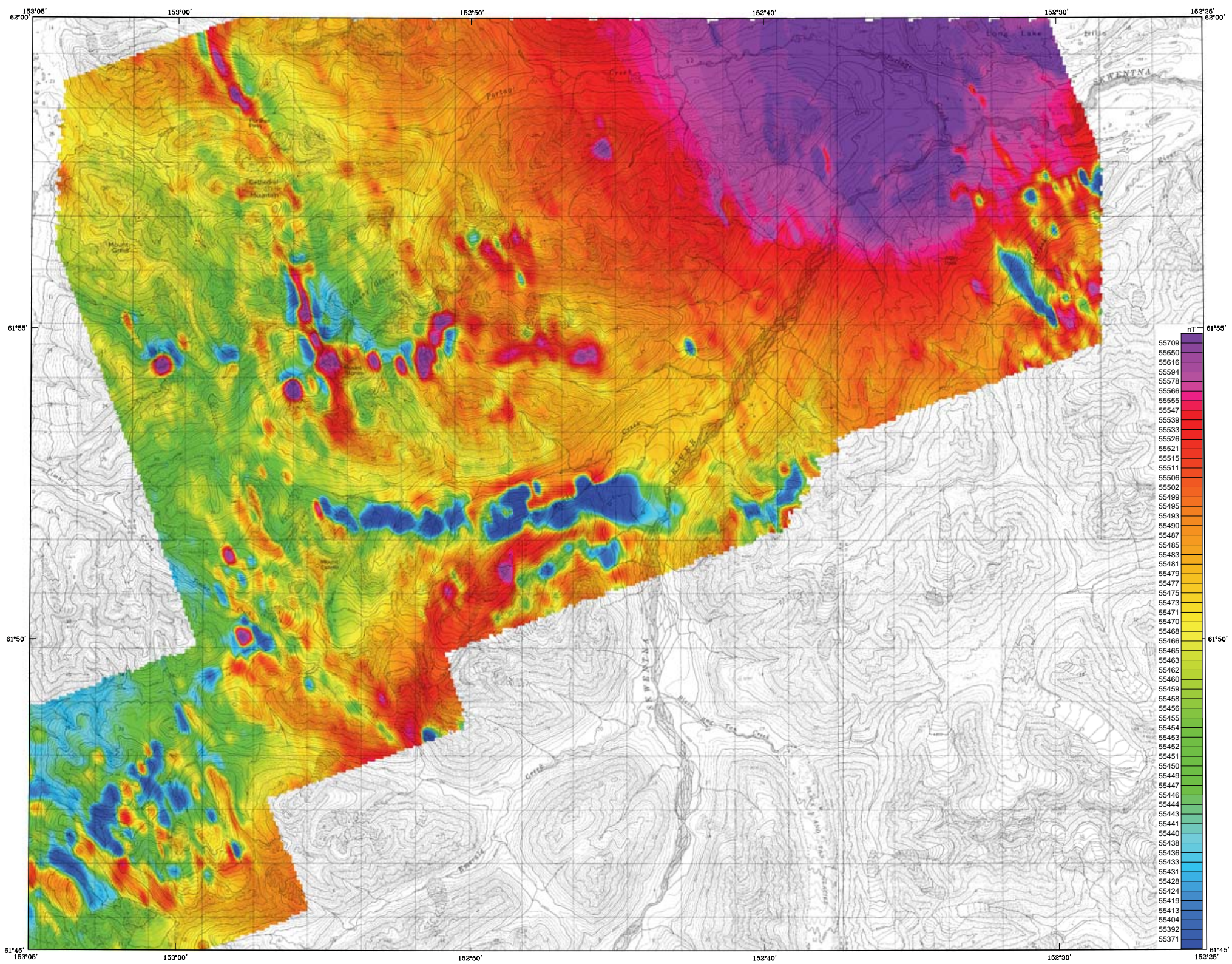

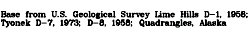

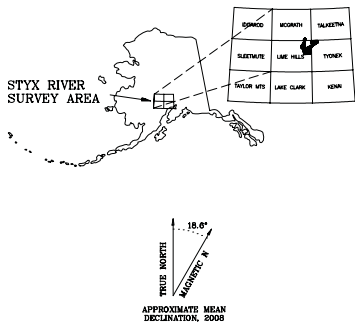

DESCRIPTIVE NOTES

\section{TOTAL MAGNETIC FIELD OF THE EASTERN STYX RIVER SURVEY, SOUTHCENTRAL ALASKA \\ PARTS OF LIME HILLS and TYONEK QUADRANGLES} Laurol E. Bums, Fugro Airomeme Surveys Corp., and Stevens Exploratton Management Corp.
2008

TOTAL MAGNETIC FIELD

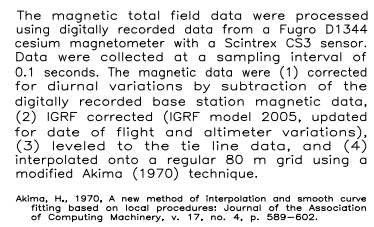

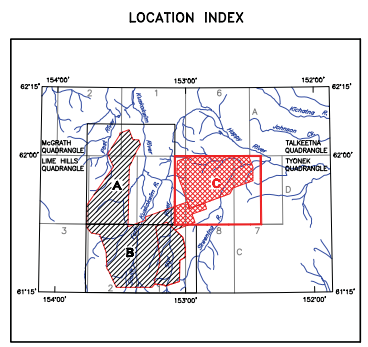

SURVEY HISTORY

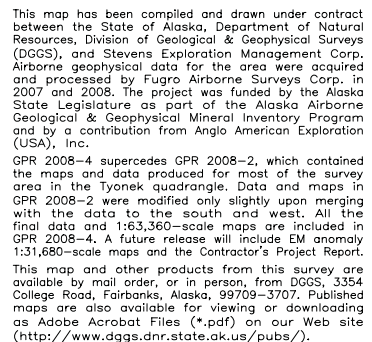




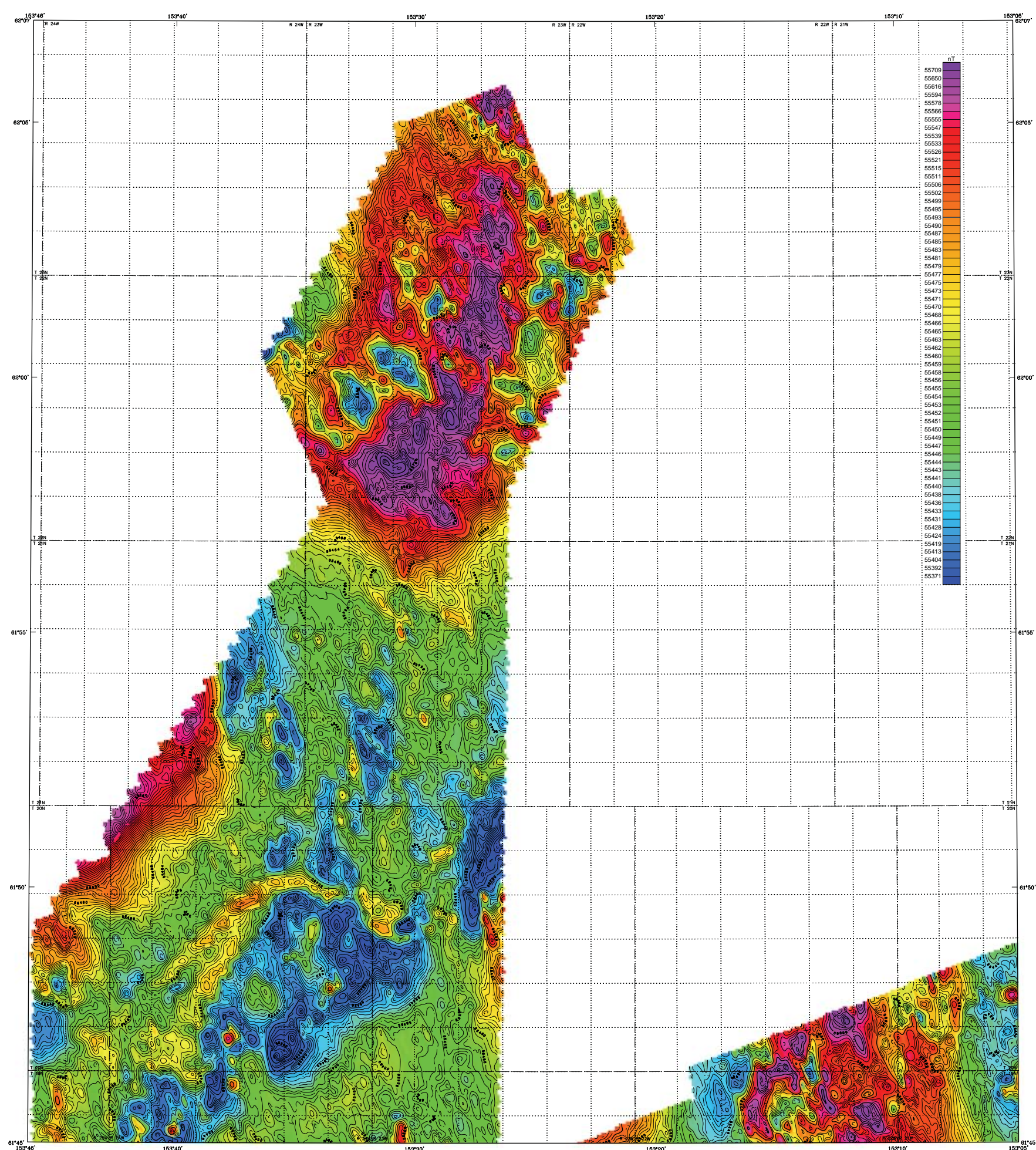

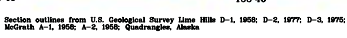

STRX RVVR O

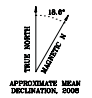

DESCRIPTIV NOTIS
SCALE $1: 63,360$

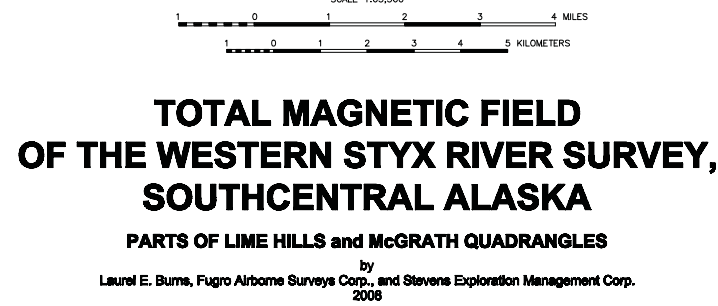

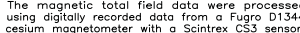

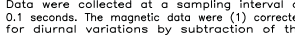

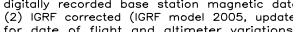

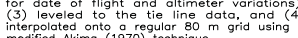

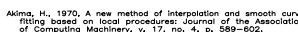

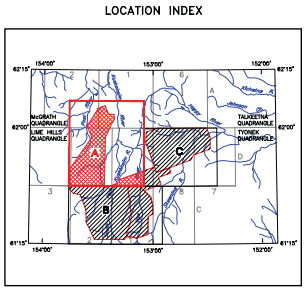

SURVEY HISTORY

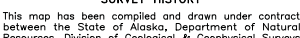

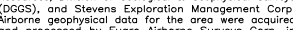

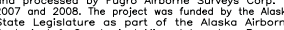




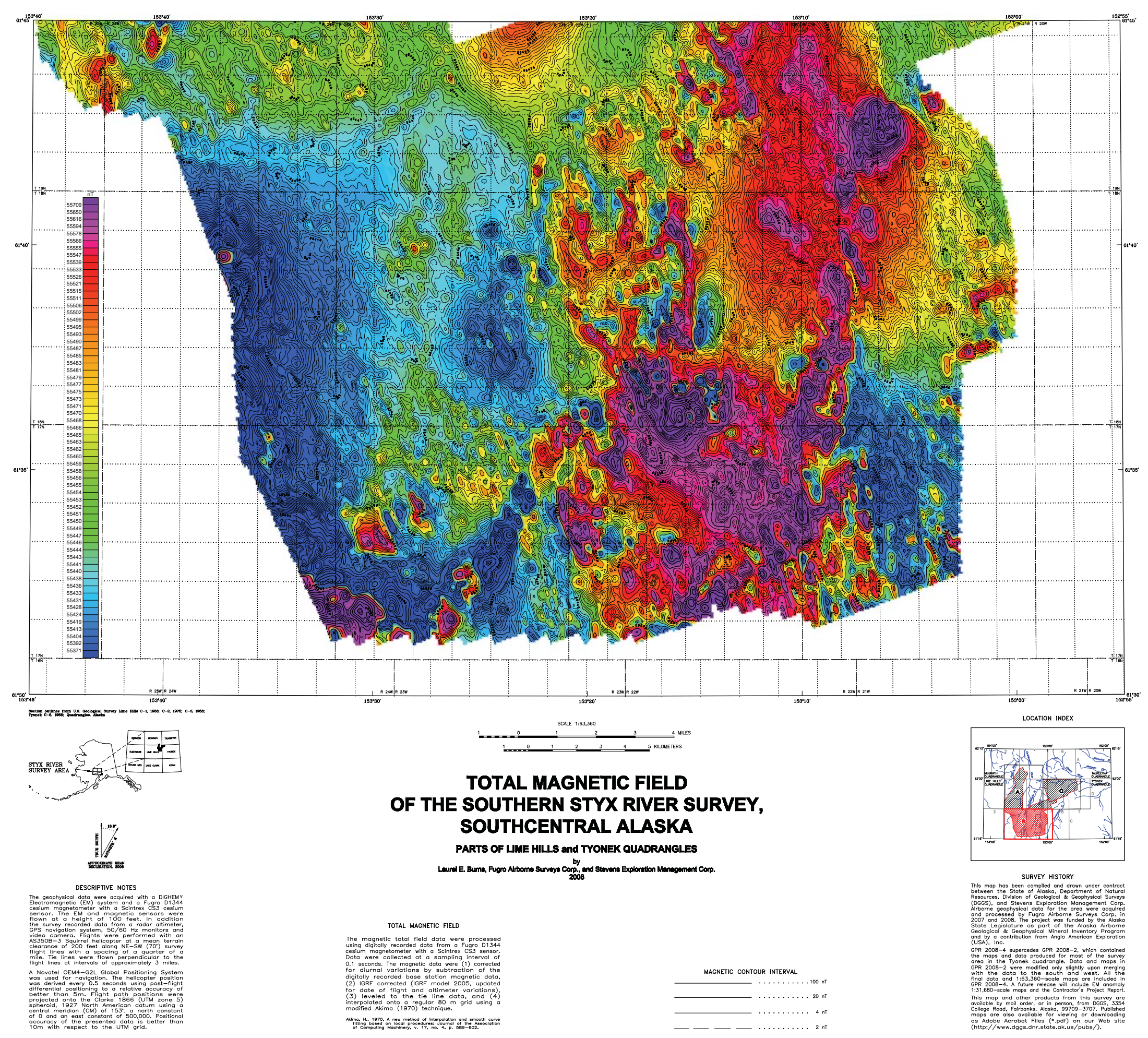




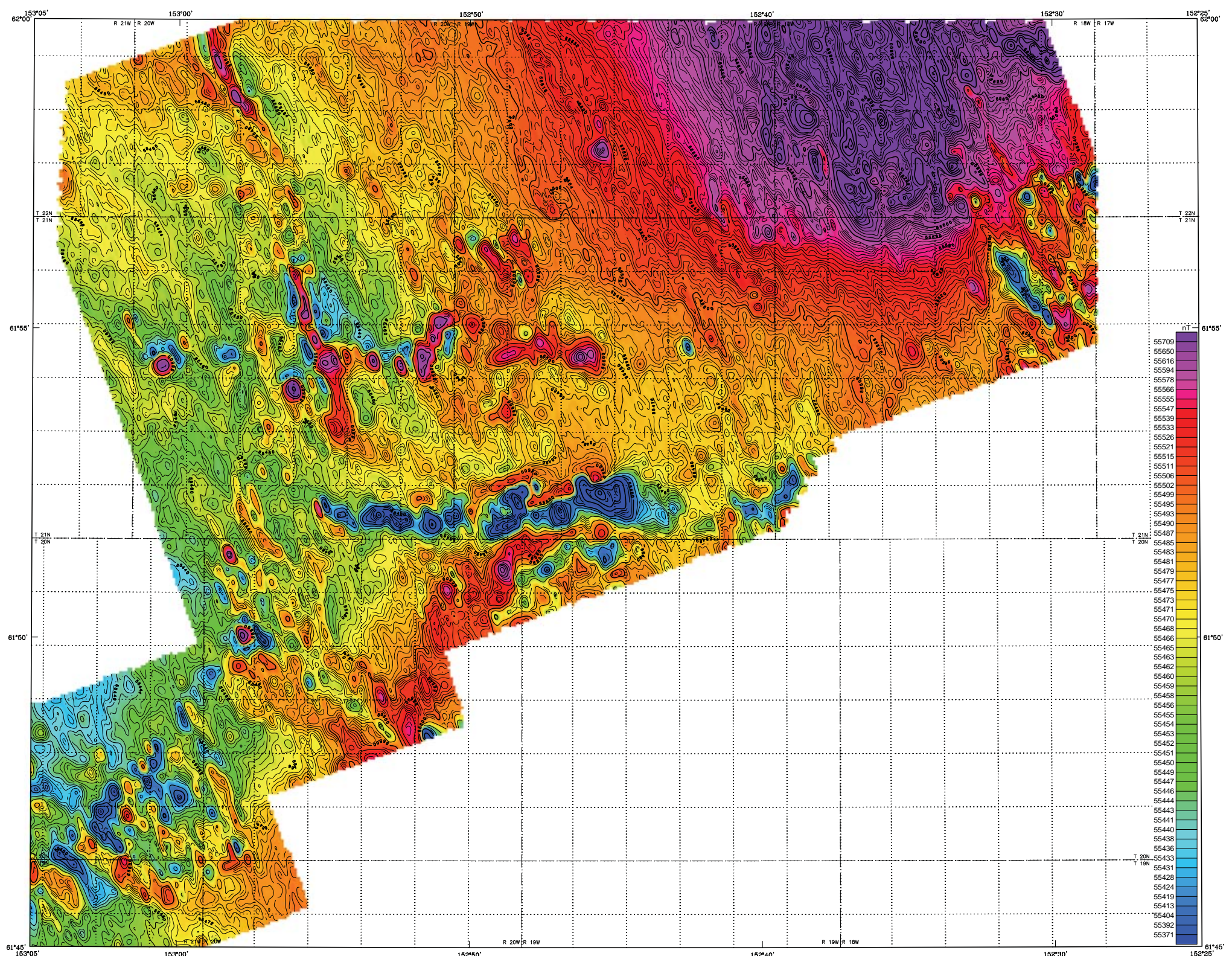

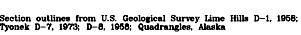

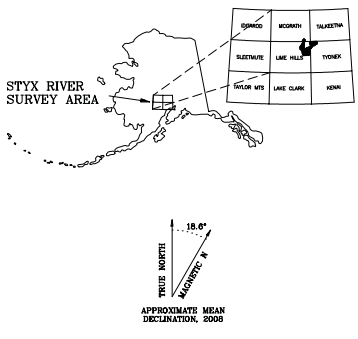

DESCRIPTIVE NOTES

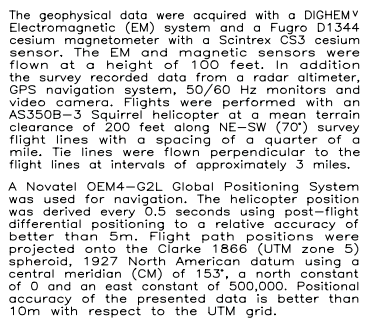

SCALE $1: 63,360$

TOTAL MAGNETIC FIELD OF THE EASTERN STYX RIVER SURVEY, SOUTHCENTRAL ALASKA

PARTS OF LIME HILLS and TYONEK QUADRANGLES

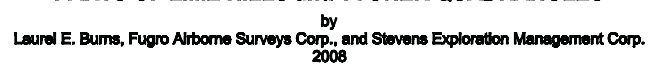

TOTAL MAGNETIC FIELD

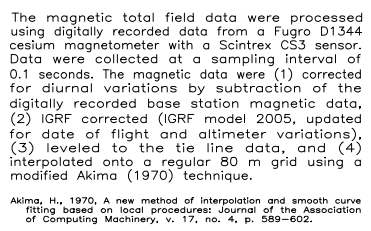

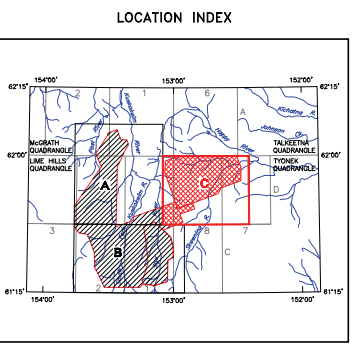

SURVEY HISTORY

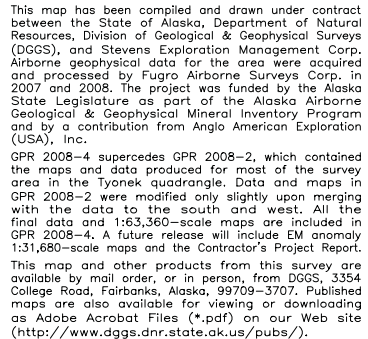




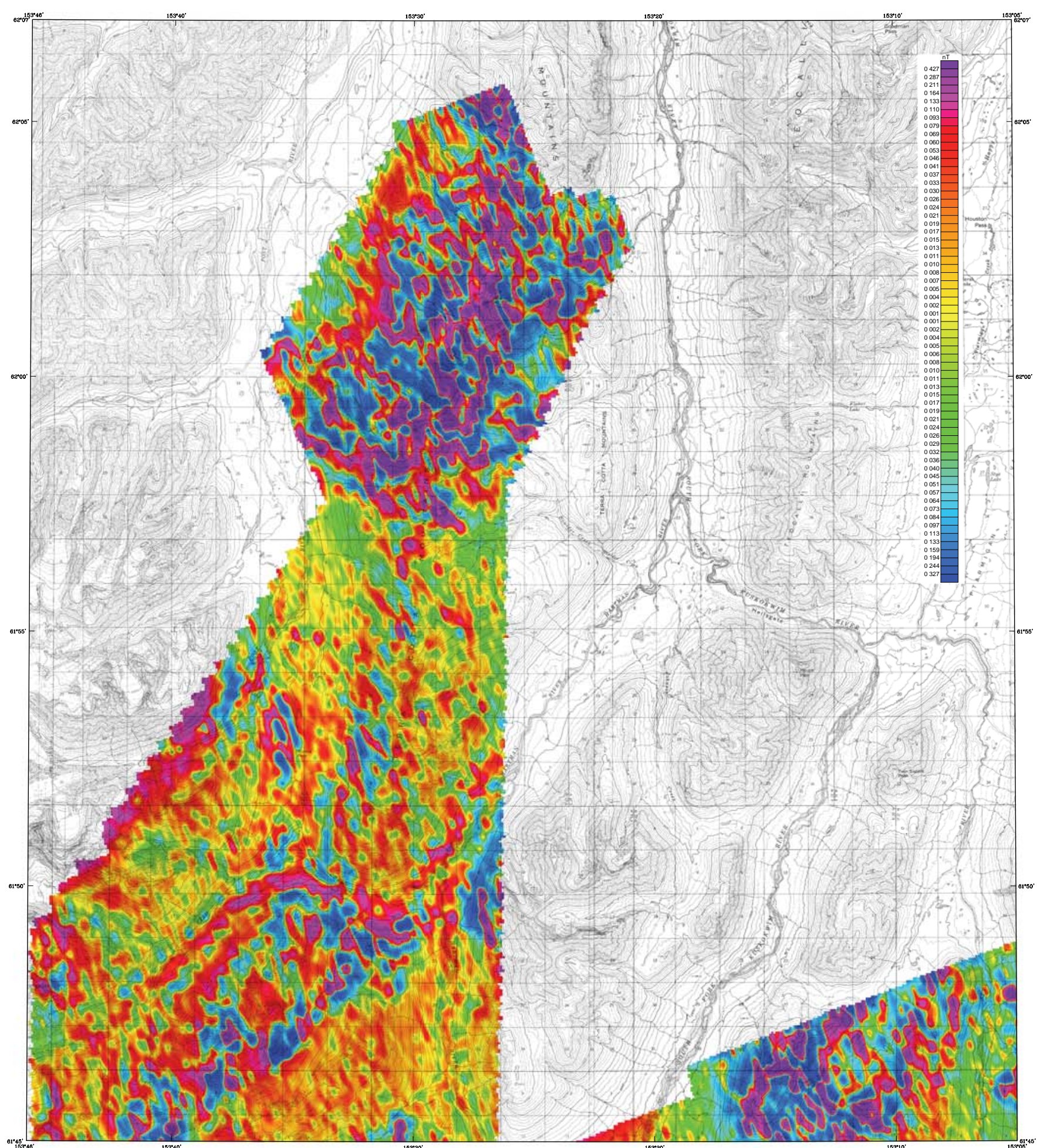

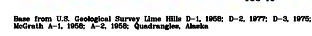

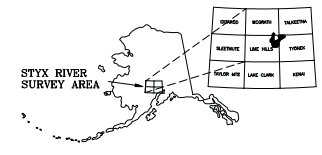

FIRST VERTICAL DERIVATIVE OF THE MAGNETIC FIELD OF THE WESTERN STYX RIVER SURVEY, SOUTHCENTRAL ALASKA

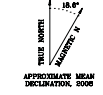

DESCRIPTIVE NOTES

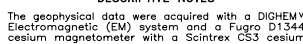

PARTS OF LIME HILLS and McGRATH QUADRANGLES

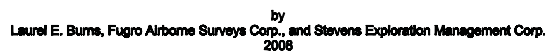

FIRST VERTICAL DERIVATIVE OF
THE MAGNETIC FIELD OF

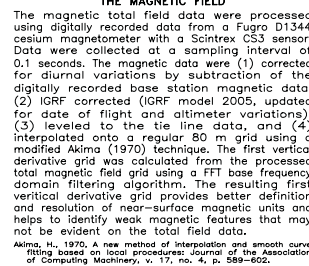

LOCATION INDEX

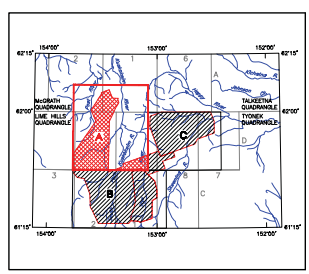

SURVEY HISTORY

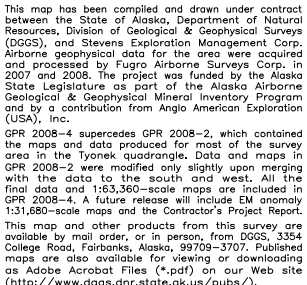




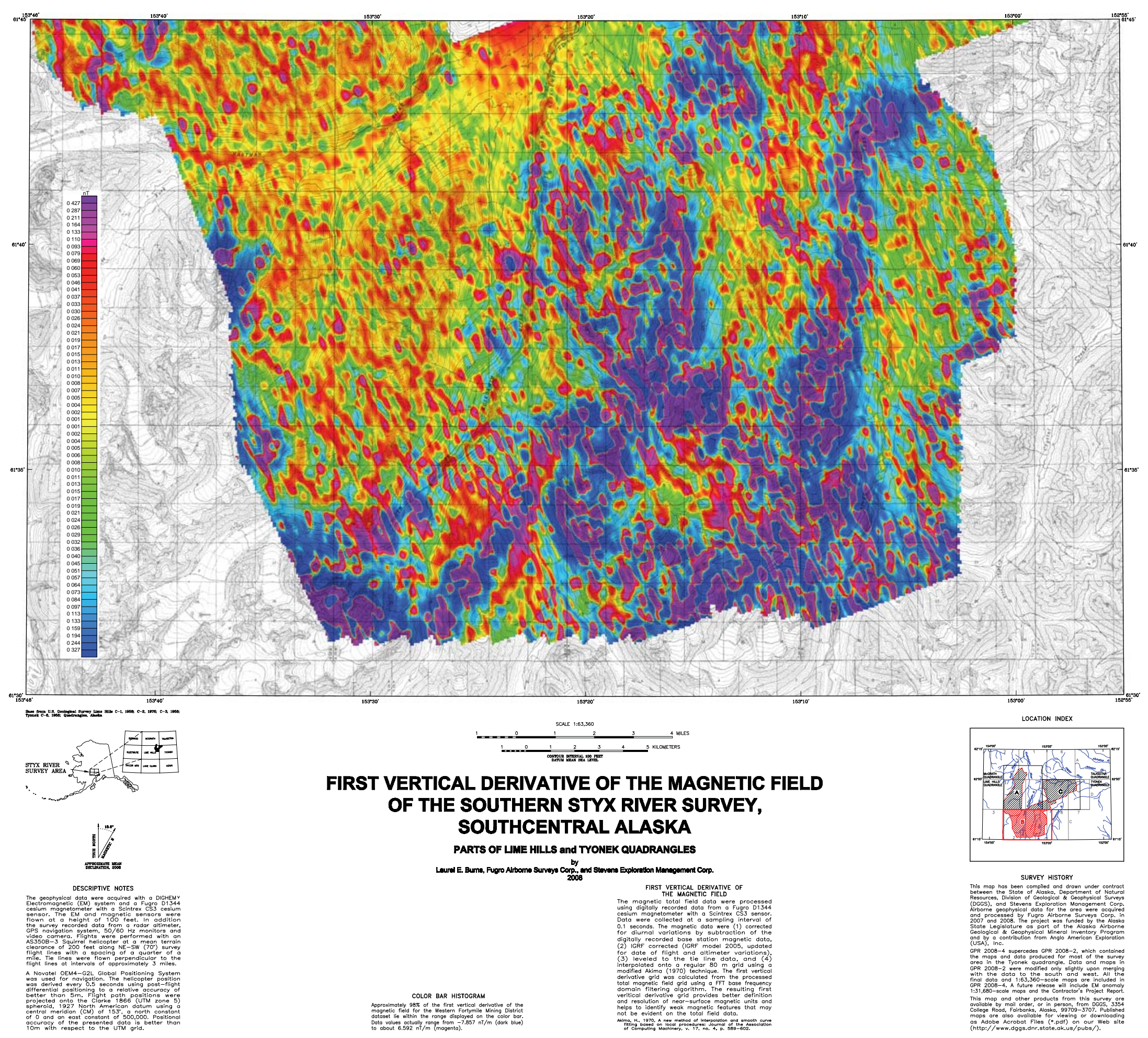




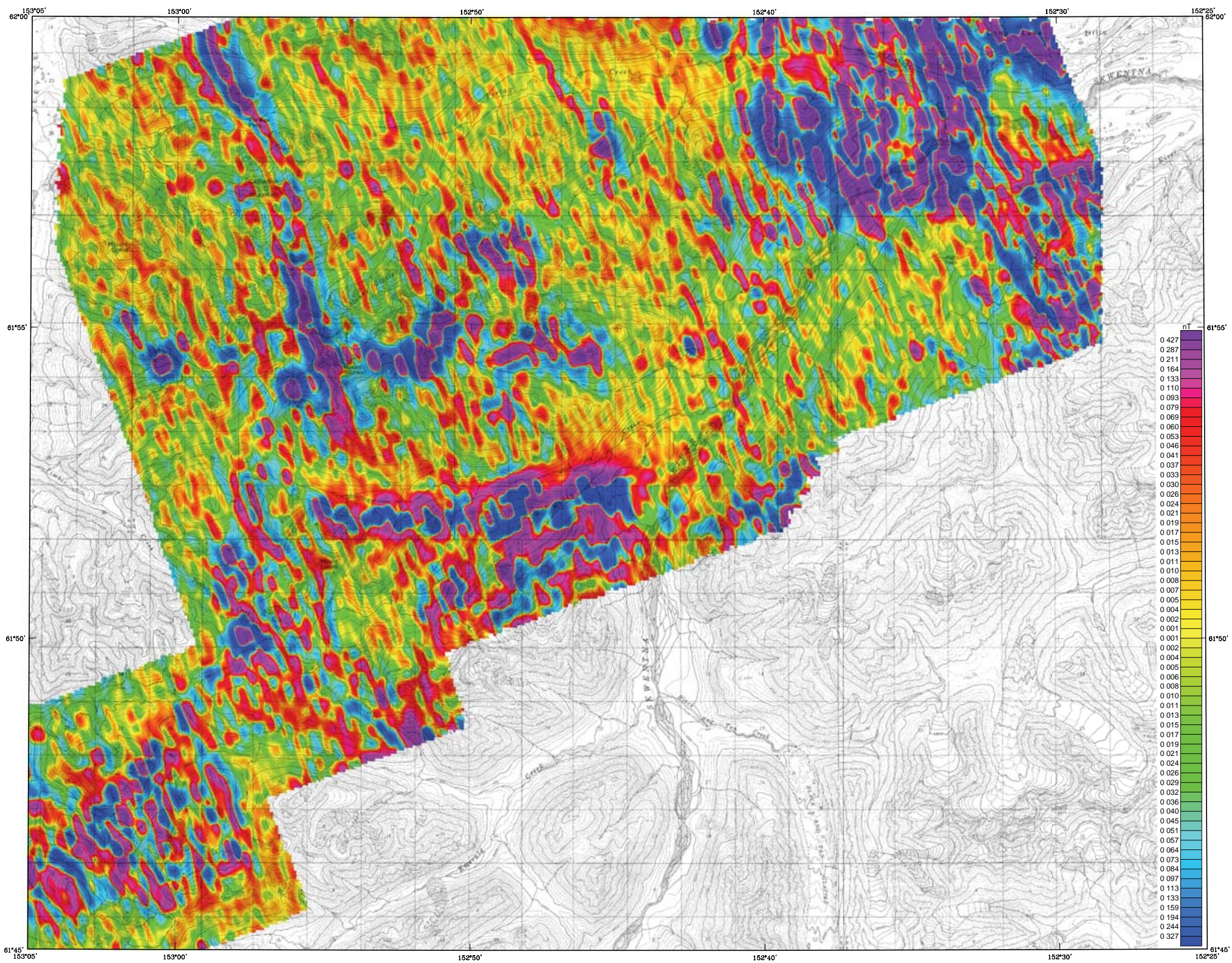

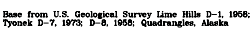

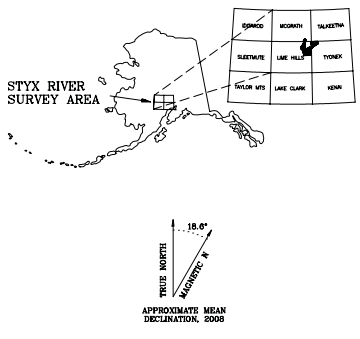

FIRST VERTICAL DERIVATIVE OF THE MAGNETIC FIELD OF THE EASTERN STYX RIVER SURVEY, SOUTHCENTRAL ALASKA

PARTS OF LIME HILLS and TYONEK QUADRANGLES Laurol E. Bums, Fugro Artoome Surveys Corp., and Stevens Exploratton Management Corp.
2008

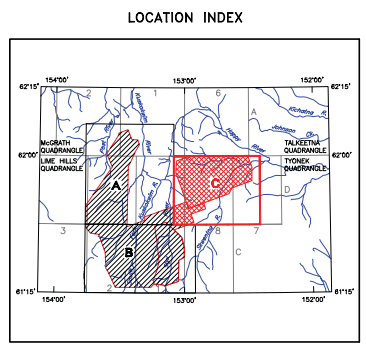

DESCRIPTIVE NOTES
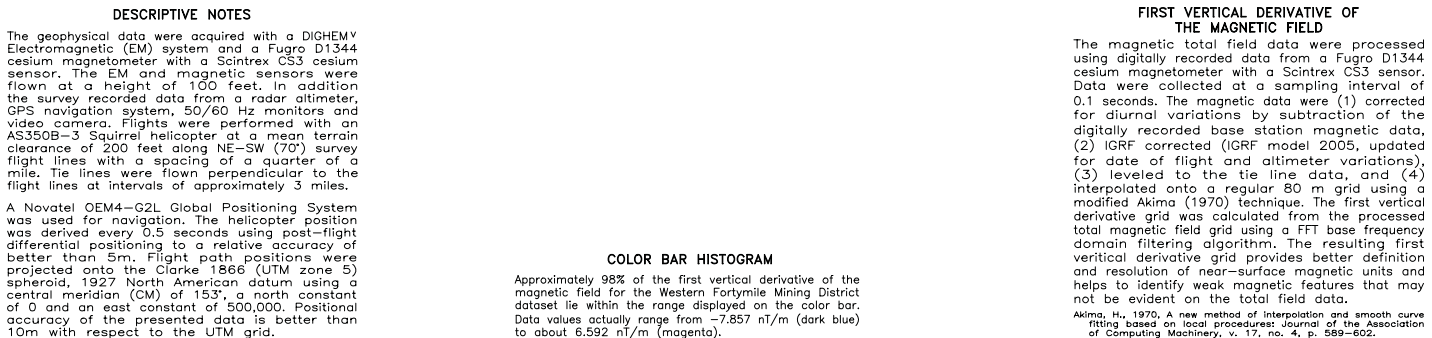

SURVEY HISTORY

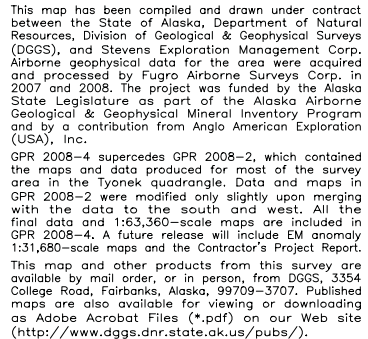




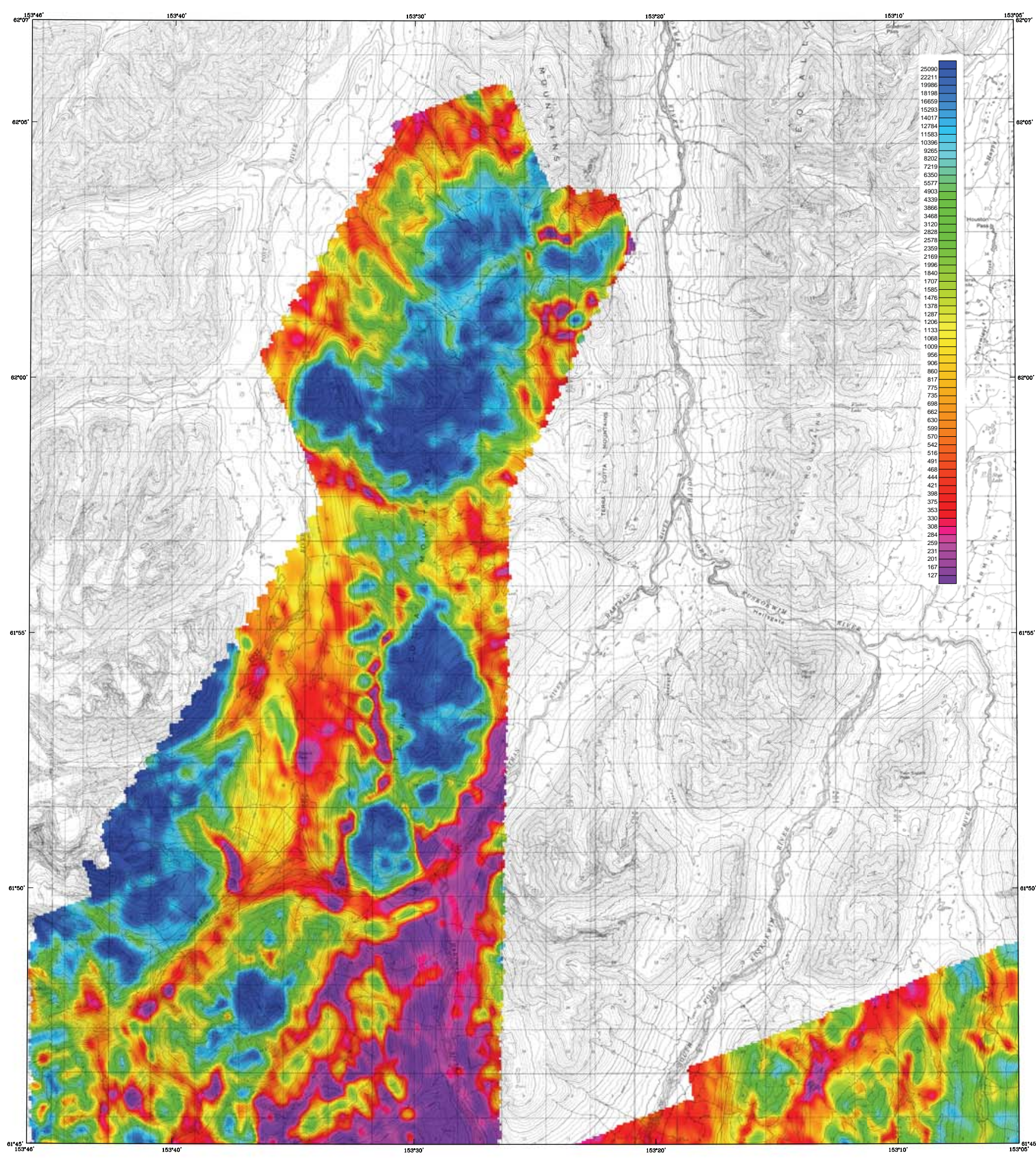

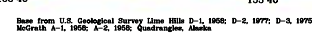

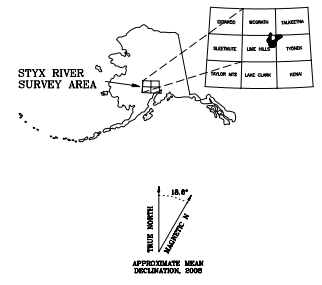

\section{$56,000 \mathrm{~Hz}$ COPLANAR APPARENT RESISTIVITY OF THE WESTERN STYX RIVER SURVEY, SOUTHCENTRAL ALASKA}

PARTS OF LIME HILLS and McGRATH QUADRANGLES
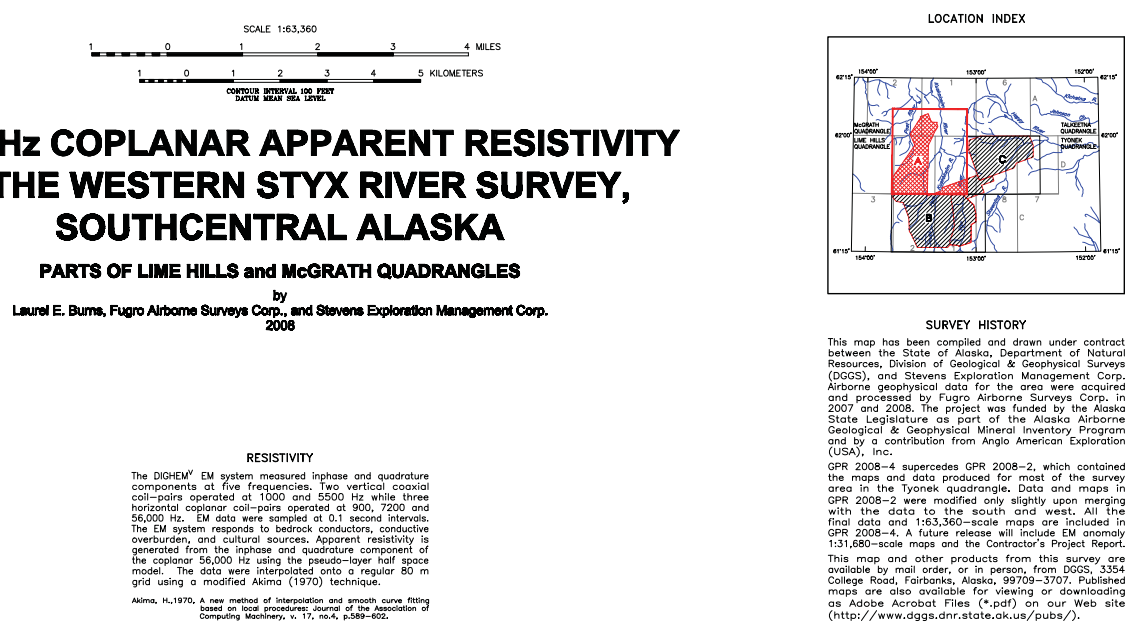


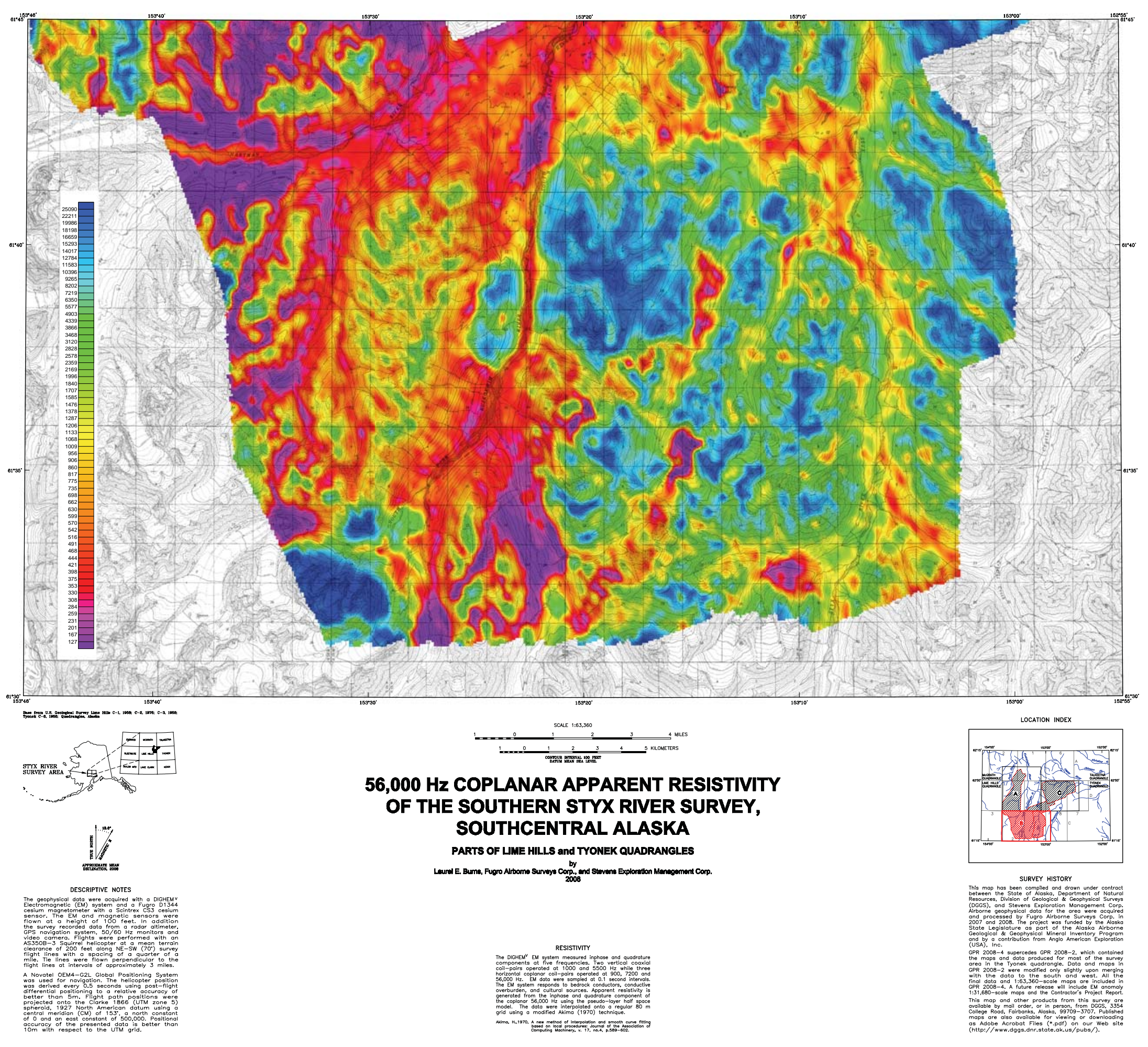




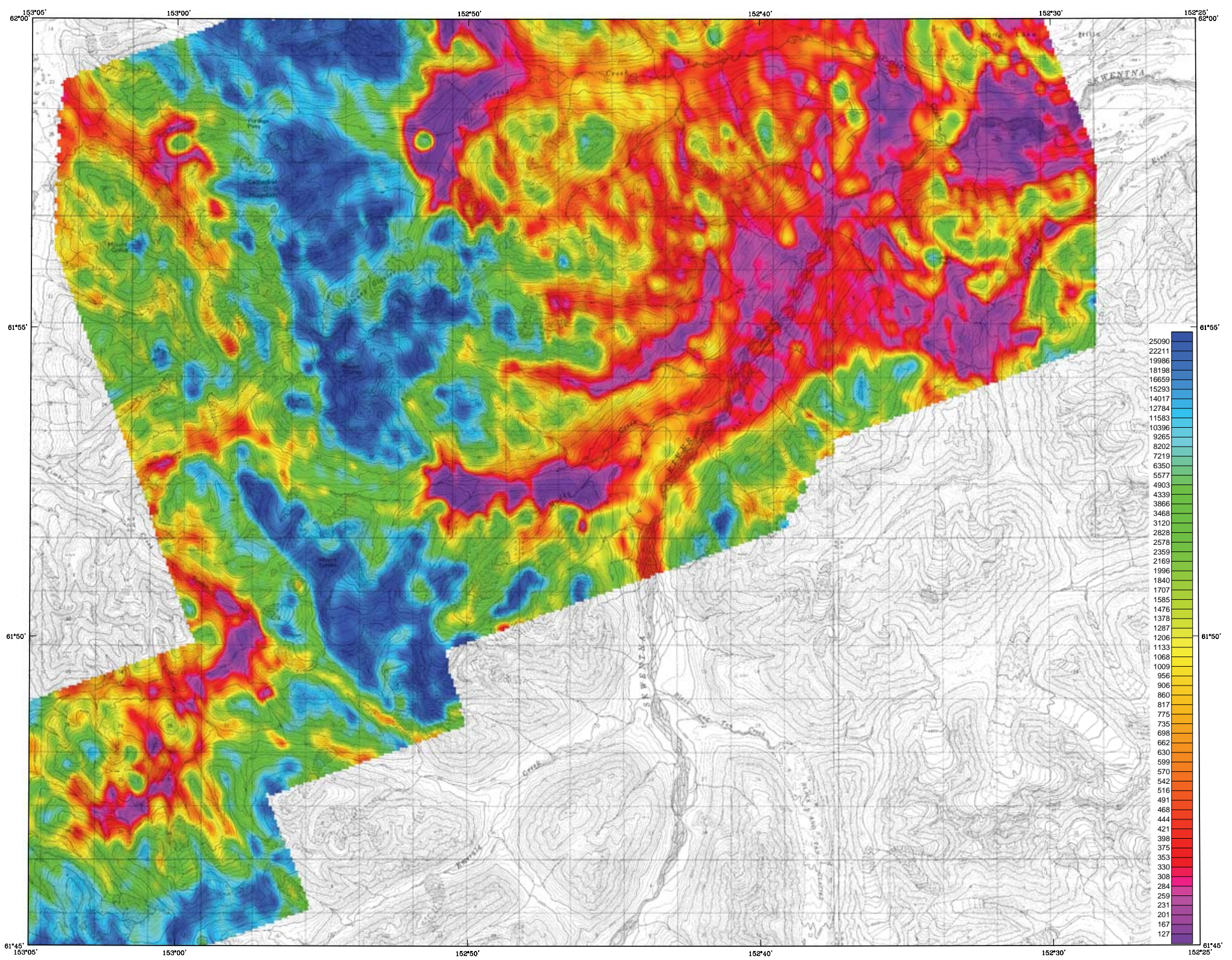

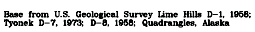

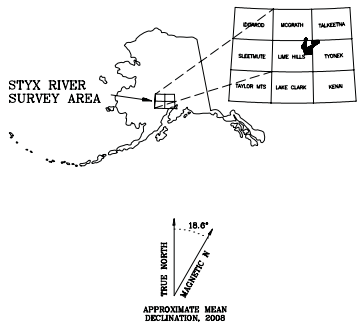
$56,000 \mathrm{~Hz}$ COPLANAR APPARENT RESISTIVITY
OF THE EASTERN STYX RIVER SURVEY, SOUTHCENTRAL ALASKA

PARTS OF LIME HILLS and TYONEK QUADRANGLES Laurel E. Bums, Fugro Airbome Surveys Corp., and Stevens Exploration Management Corp.

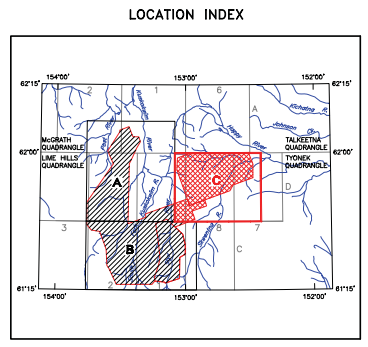

SURVEY HISTORY

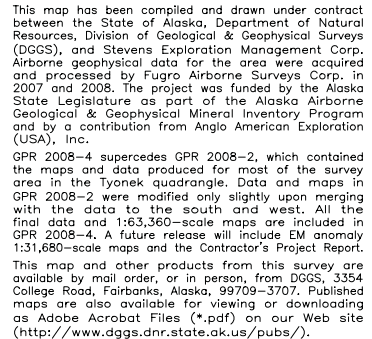




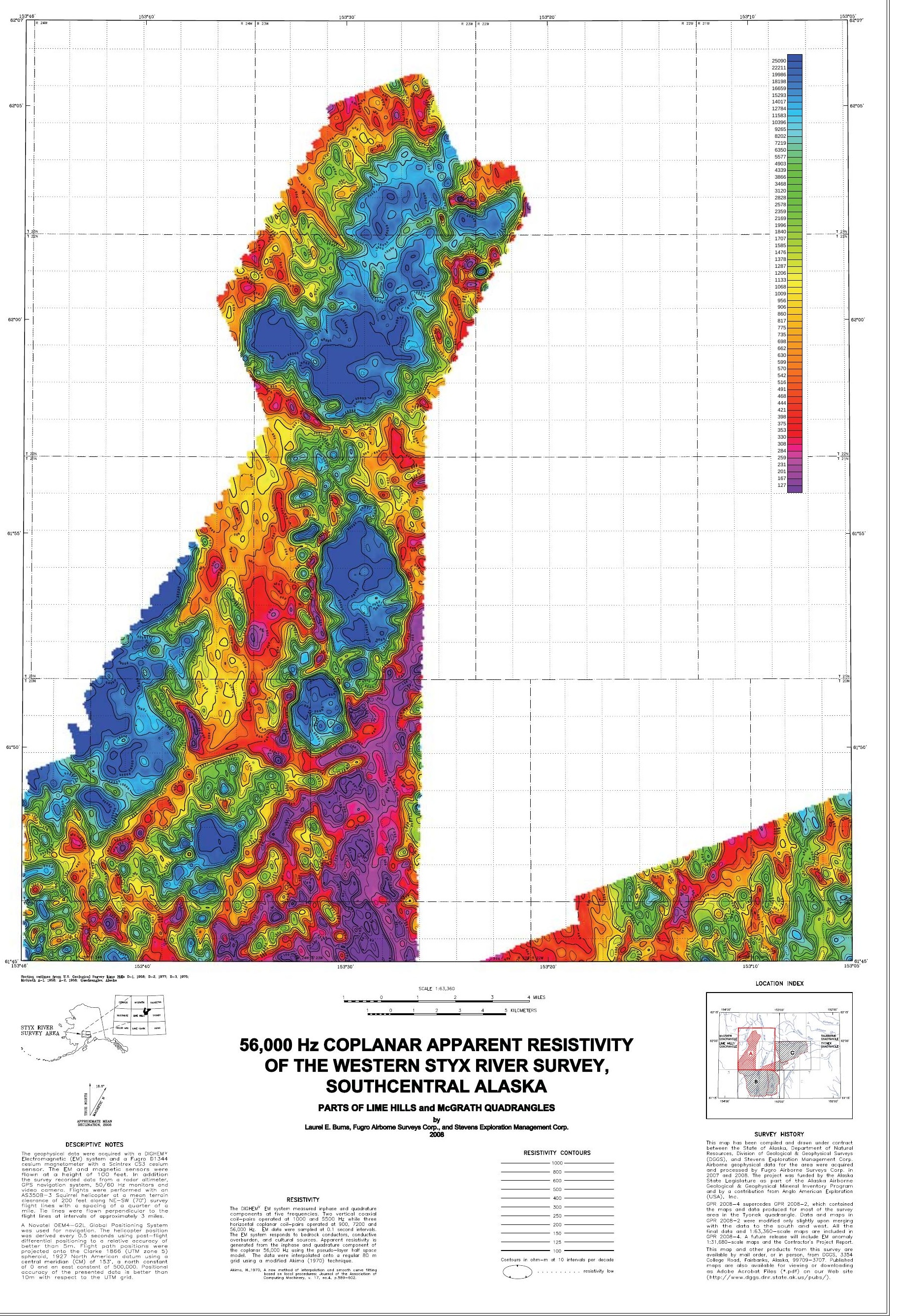




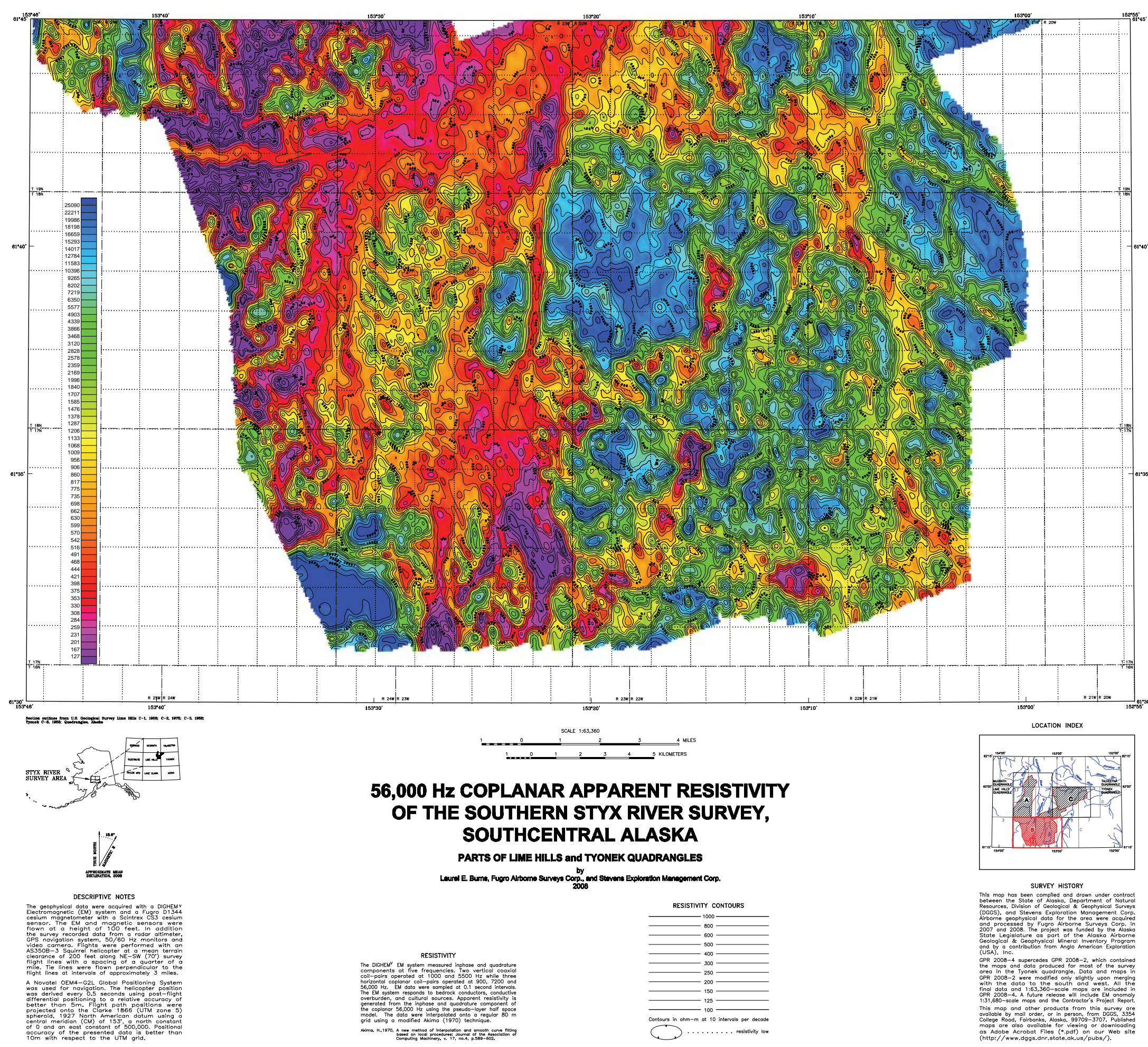




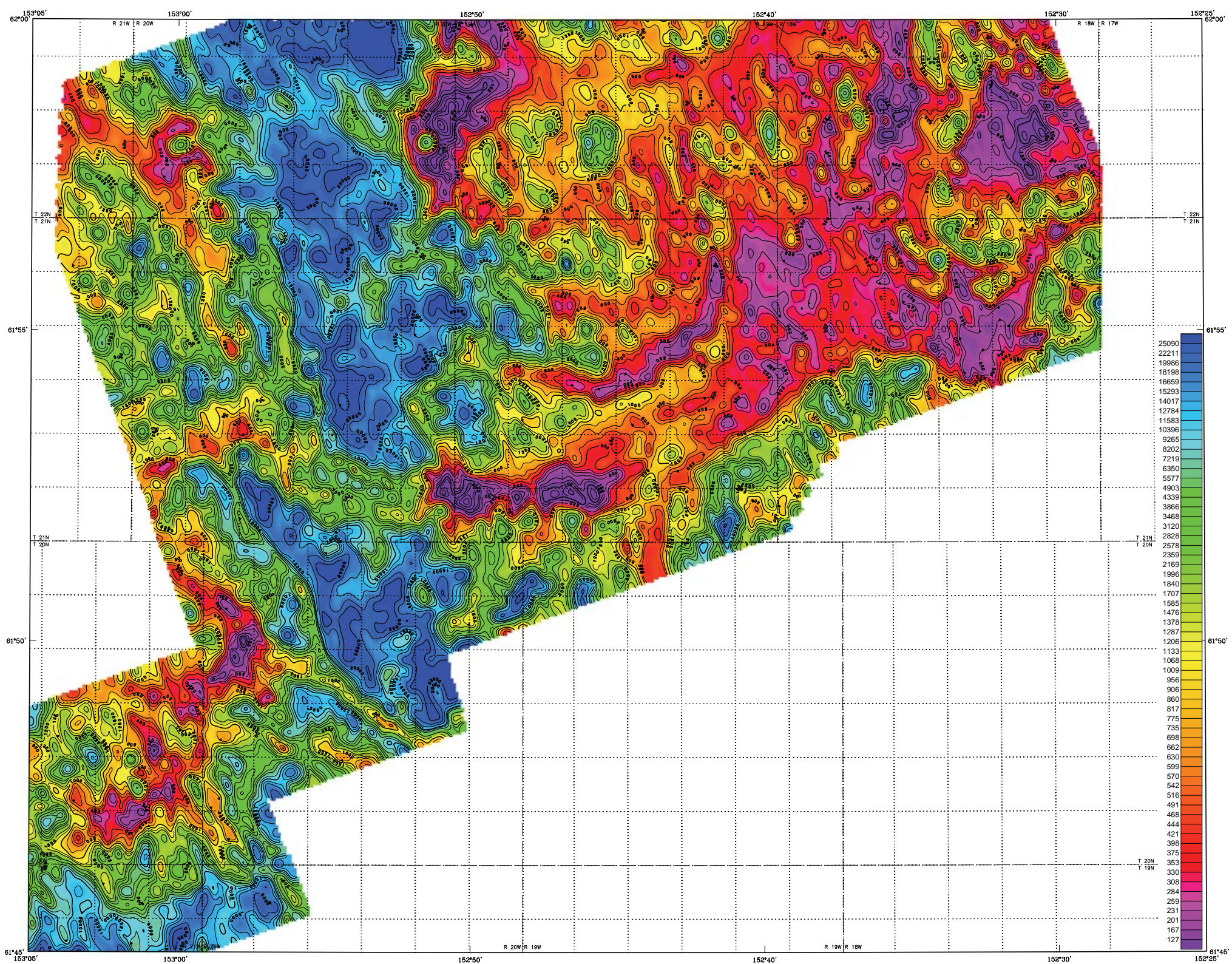

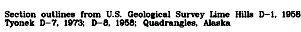

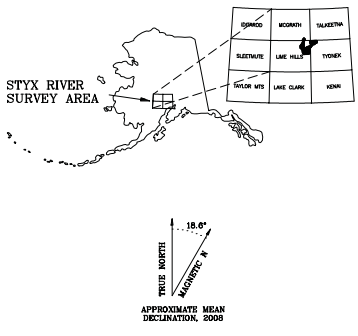

$56,000 \mathrm{~Hz}$ COPLANAR APPARENT RESISTIVITY OF THE EASTERN STYX RIVER SURVEY, SOUTHCENTRAL ALASKA

PARTS OF LIME HILLS and TYONEK QUADRANGLES

Laurel E. Bums, Fugro Aitbome Surveys Corp., and Stevens Exploration Management Corp.

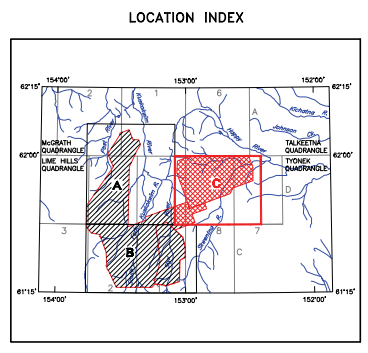

DESCRIPTIVE NOTES
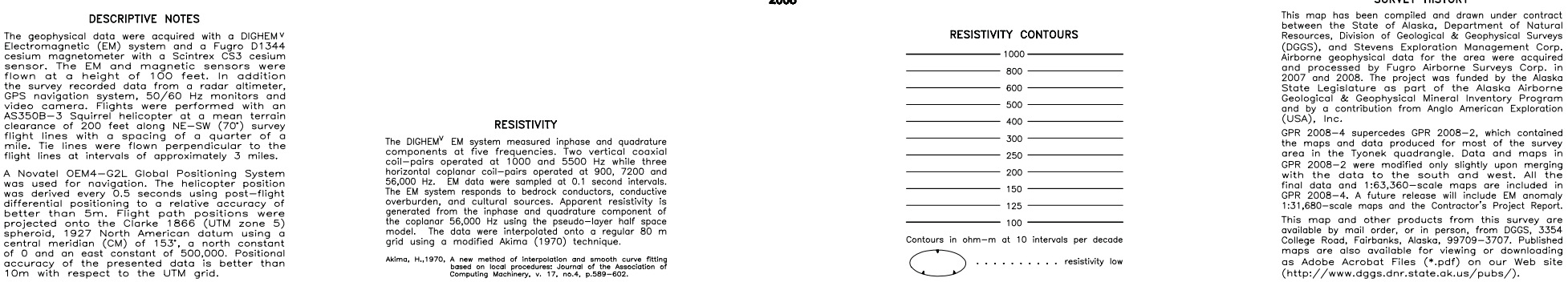


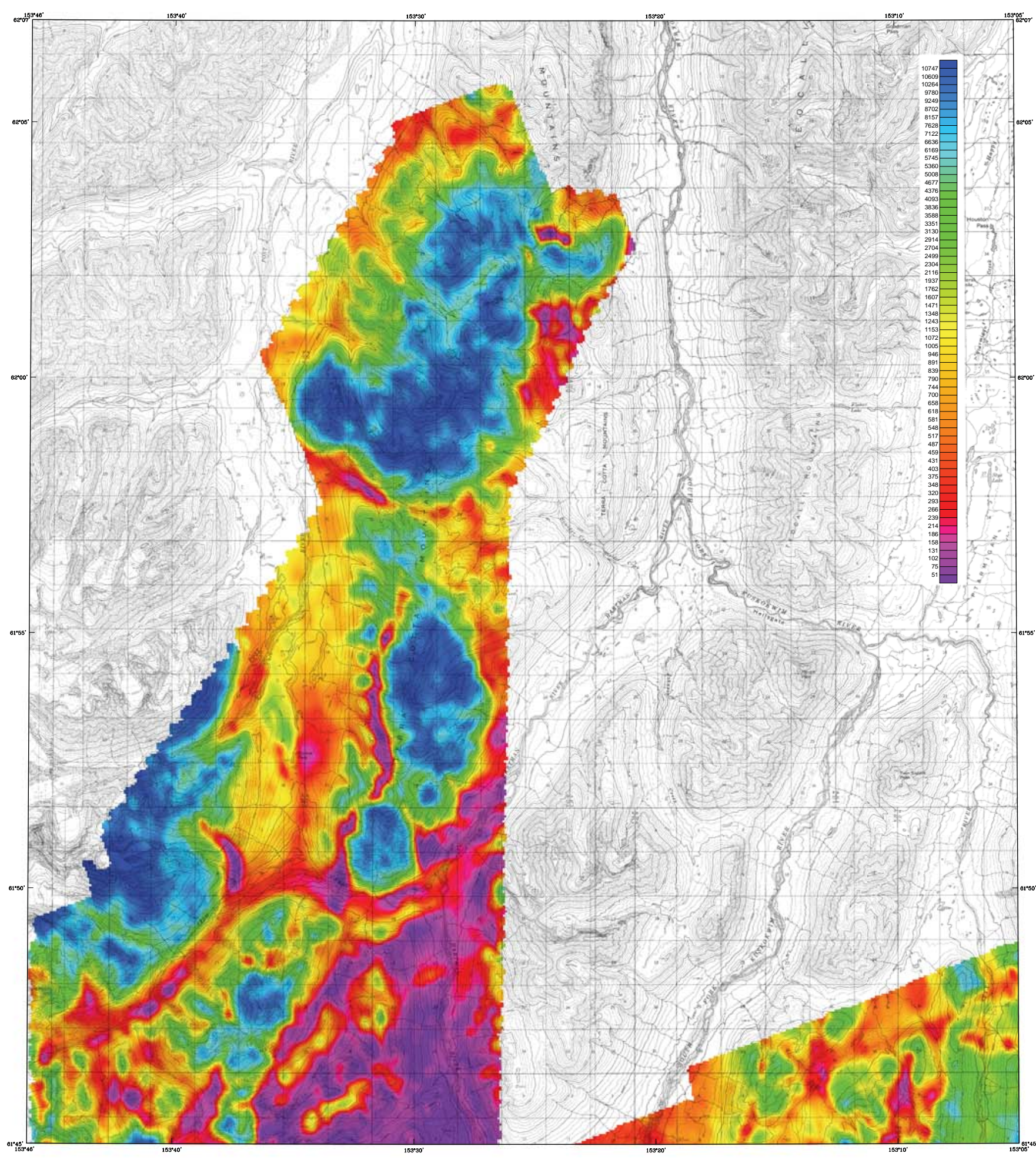

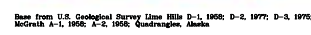

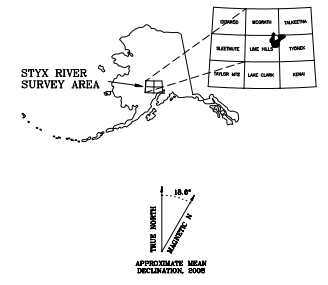

\section{$7200 \mathrm{~Hz}$ COPLANAR APPARENT RESISTIVITY OF THE WESTERN STYX RIVER SURVEY, SOUTHCENTRAL ALASKA}

PARTS OF LIME HILLS and McGRATH QUADRANGLES

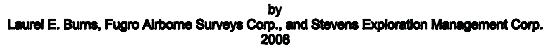

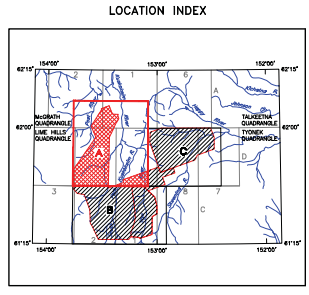

SURVEY HISTORY

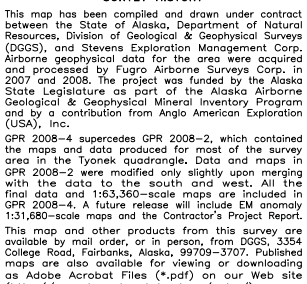




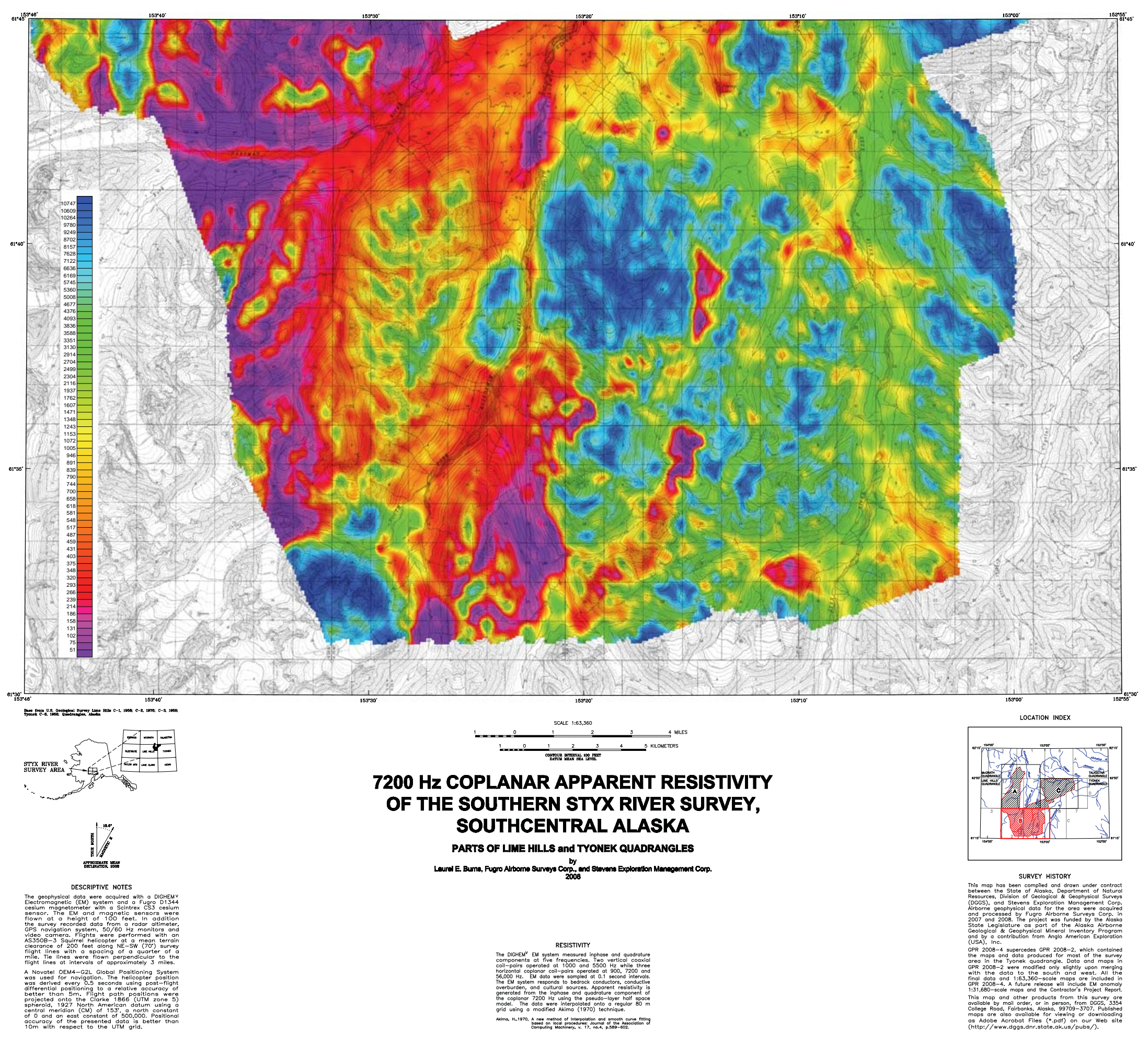




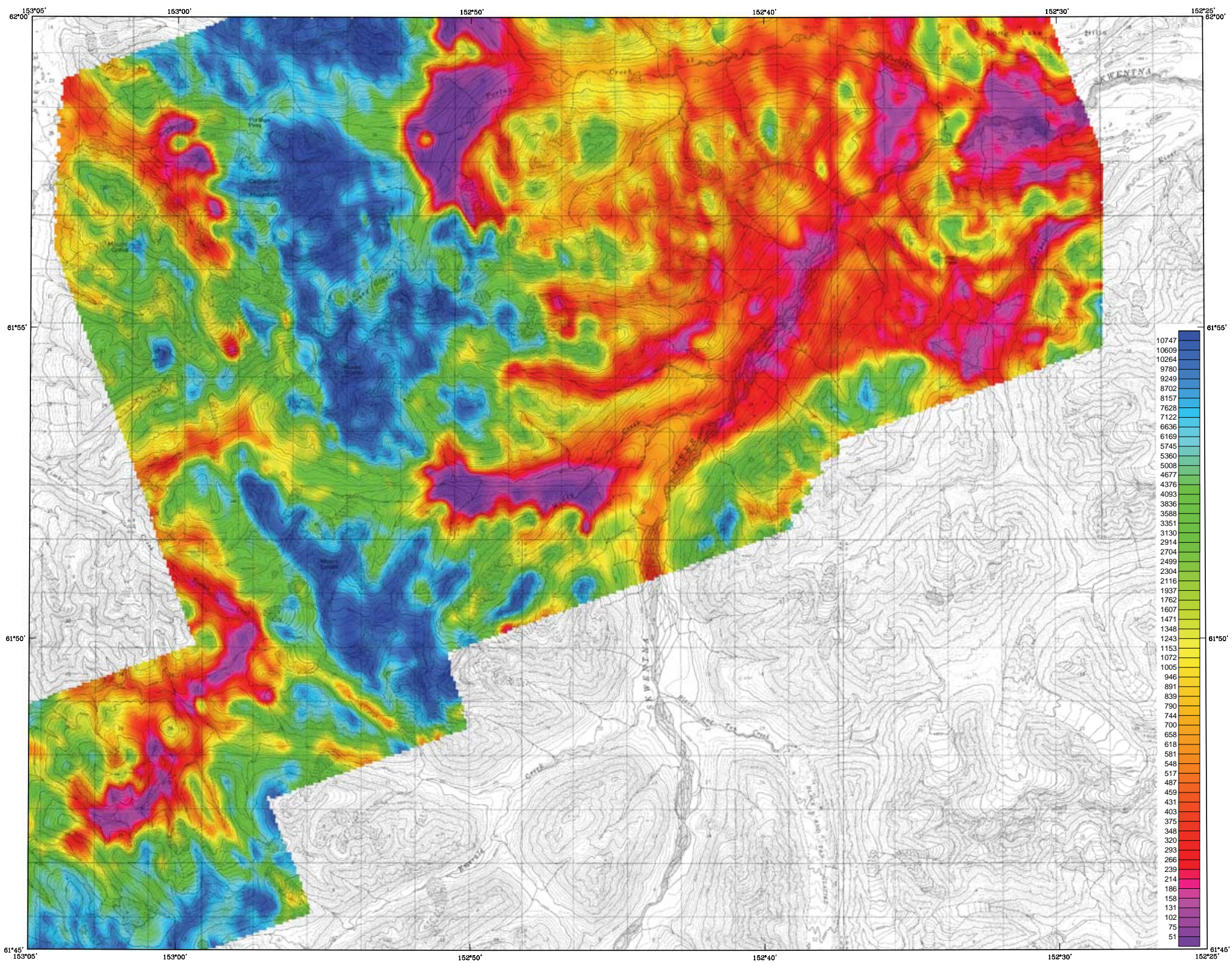

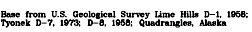

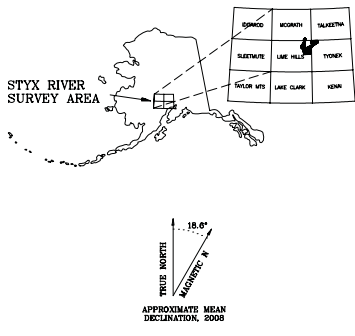
$7200 \mathrm{~Hz}$ COPLANAR APPARENT RESISTIVITY
OF THE EASTERN STYX RIVER SURVEY, SOUTHCENTRAL ALASKA

PARTS OF LIME HILLS and TYONEK QUADRANGLES
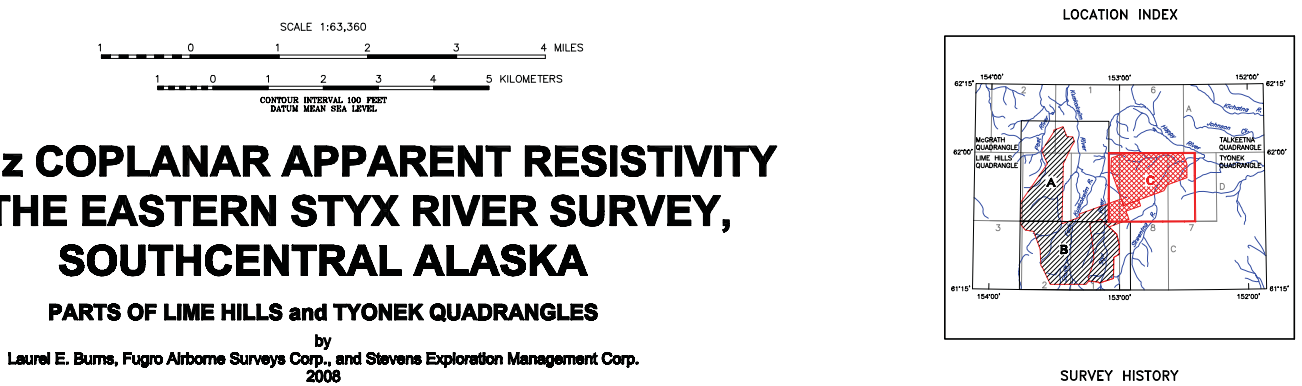

SURVEY HISTORY

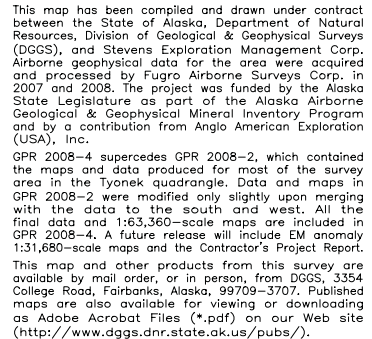




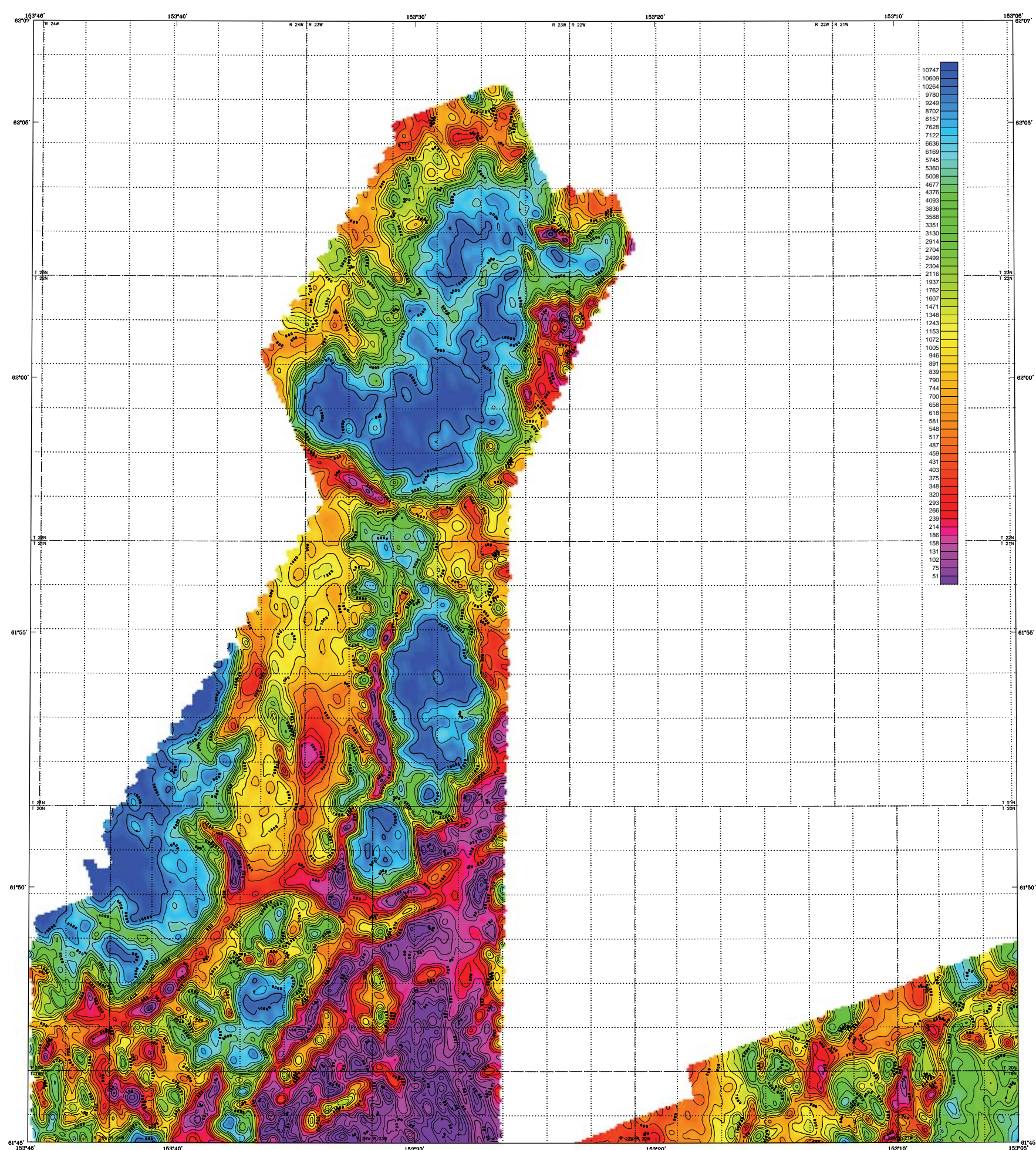

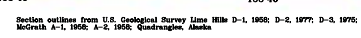
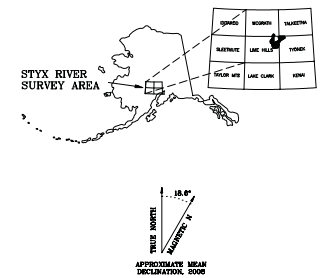

DESCRIPTIYE NOTIS

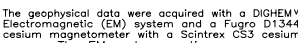

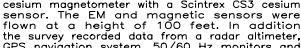

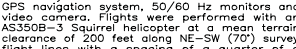

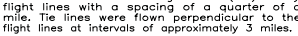

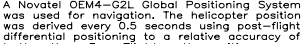

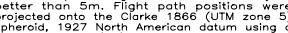

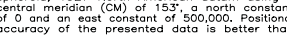

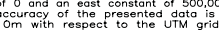

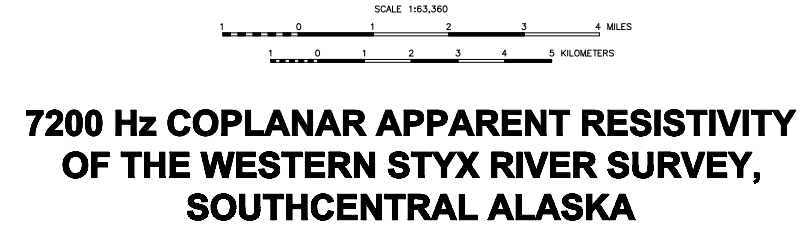

PARTS OF LIME HILLS and McGRATH QUADRANGLES
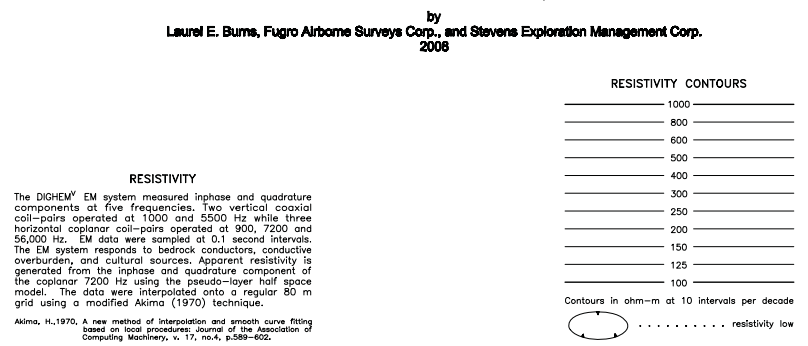

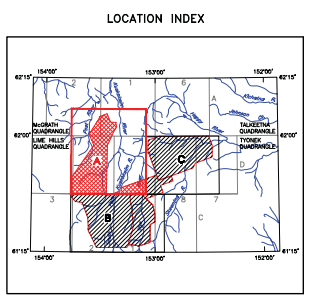

SURVEY HISTORY

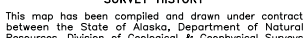

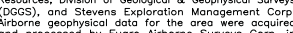

2007
2000 and 2008 . The

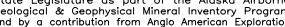

SPR $2008-4$ supercedes GPR $2008-2$, which contained
the maps and data produced for most of the surver

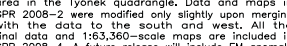

-4. A future release will include EM anomall

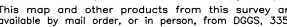




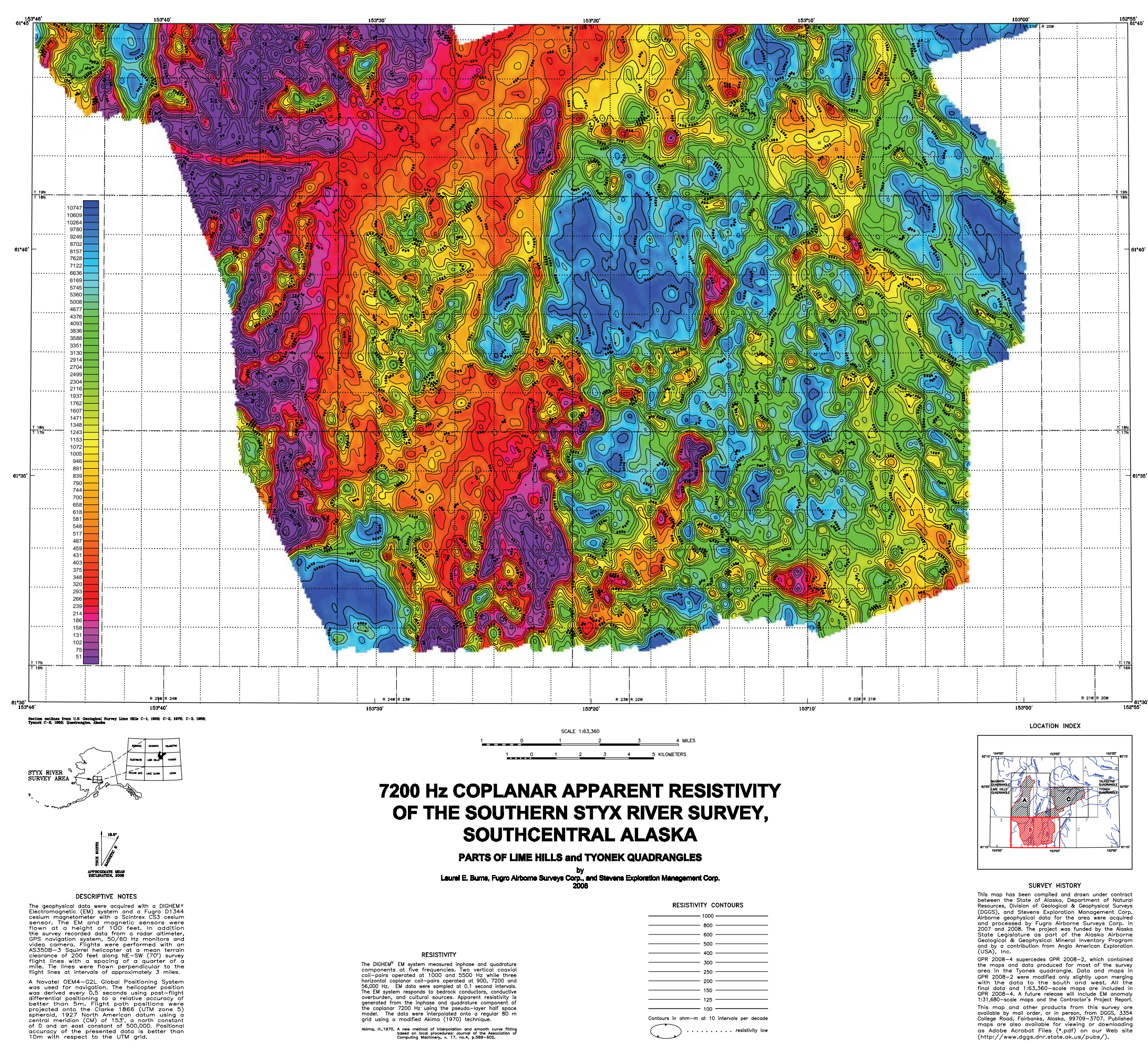




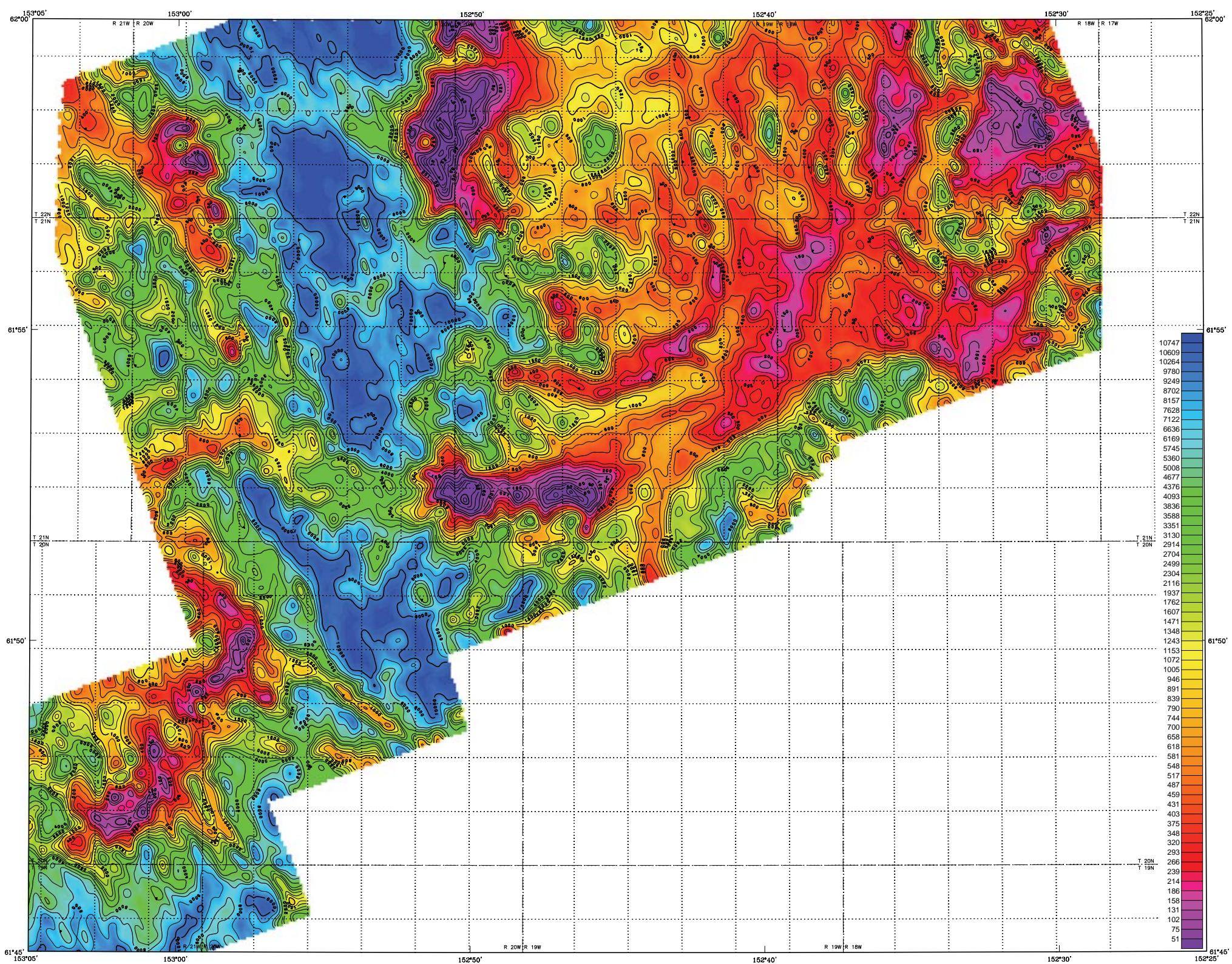

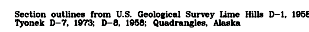

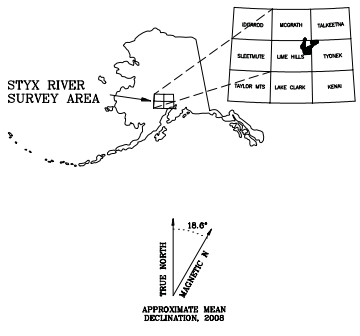

\section{$7200 \mathrm{~Hz}$ COPLANAR APPARENT RESISTIVITY OF THE EASTERN STYX RIVER SURVEY,} SOUTHCENTRAL ALASKA

PARTS OF LIME HILLS and TYONEK QUADRANGLES

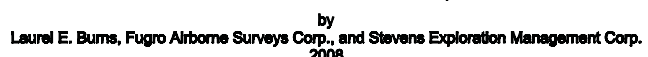

DESCRIPTIVE NOTES

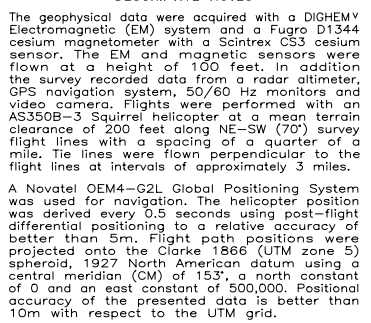

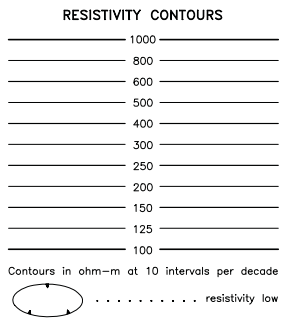

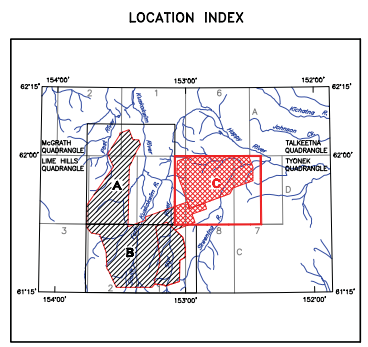

SURVEY HISTORY

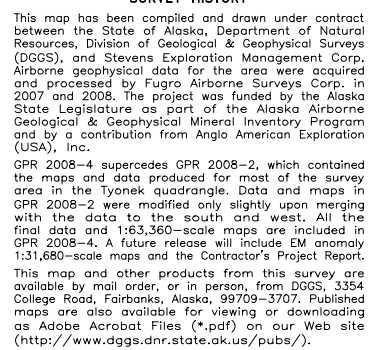




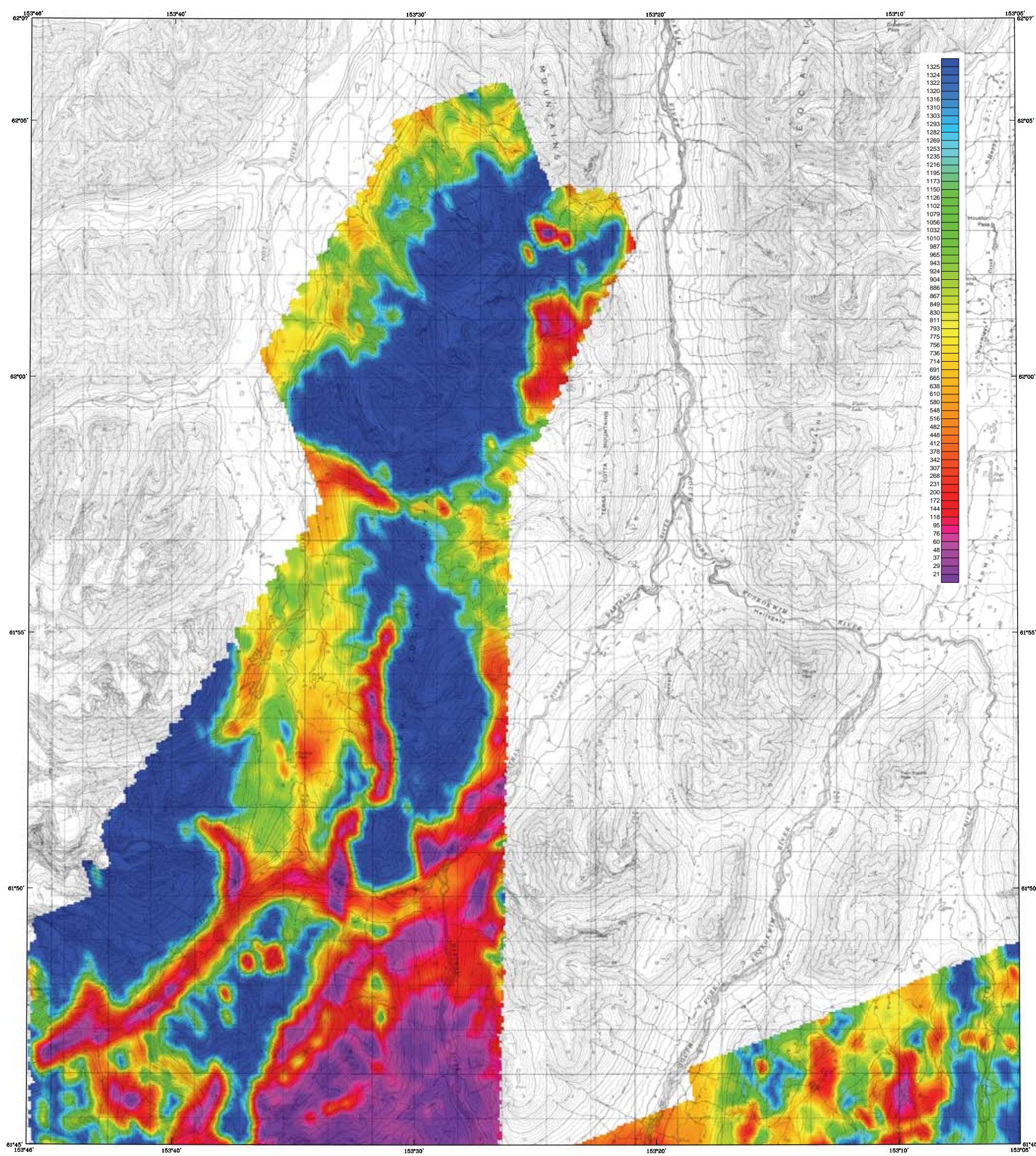

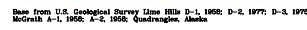
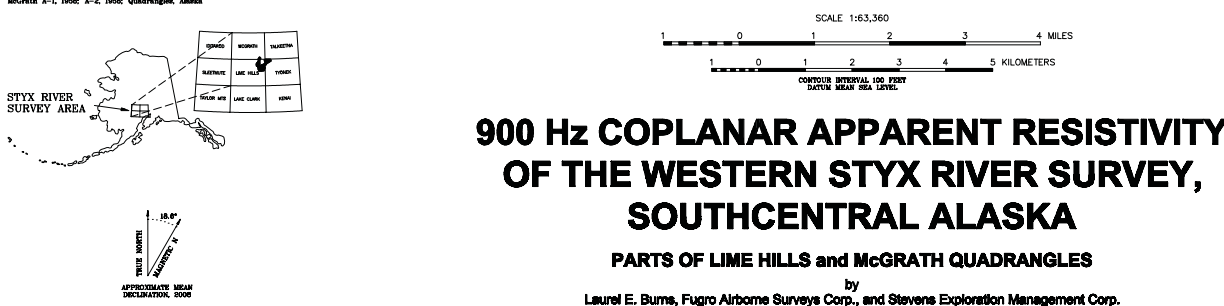

$900 \mathrm{~Hz}$ COPLANAR APPARENT RESISTIVITY OF THE WESTERN STYX RIVER SURVEY, SOUTHCENTRAL ALASKA

PARTS OF LIME HILLS and McGRATH QUADRANGLES

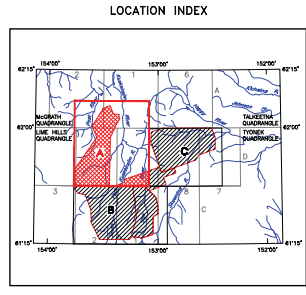

SURVEY HISTORY
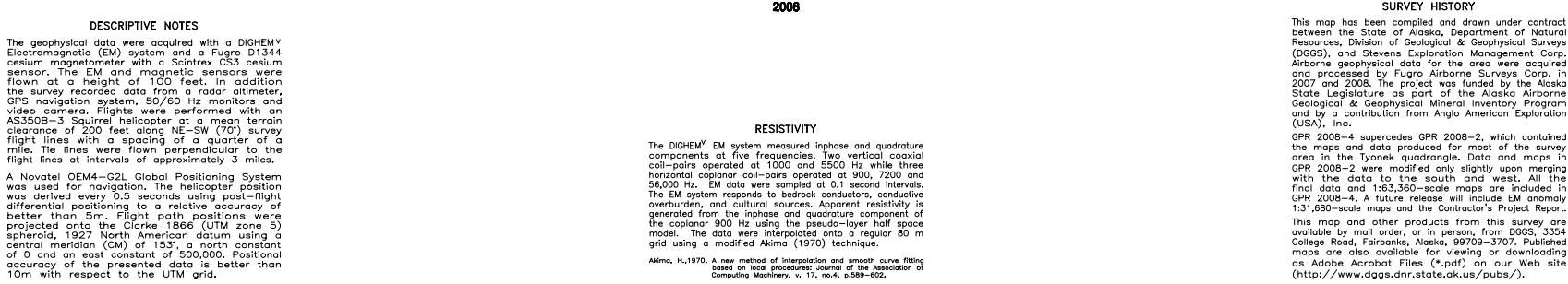


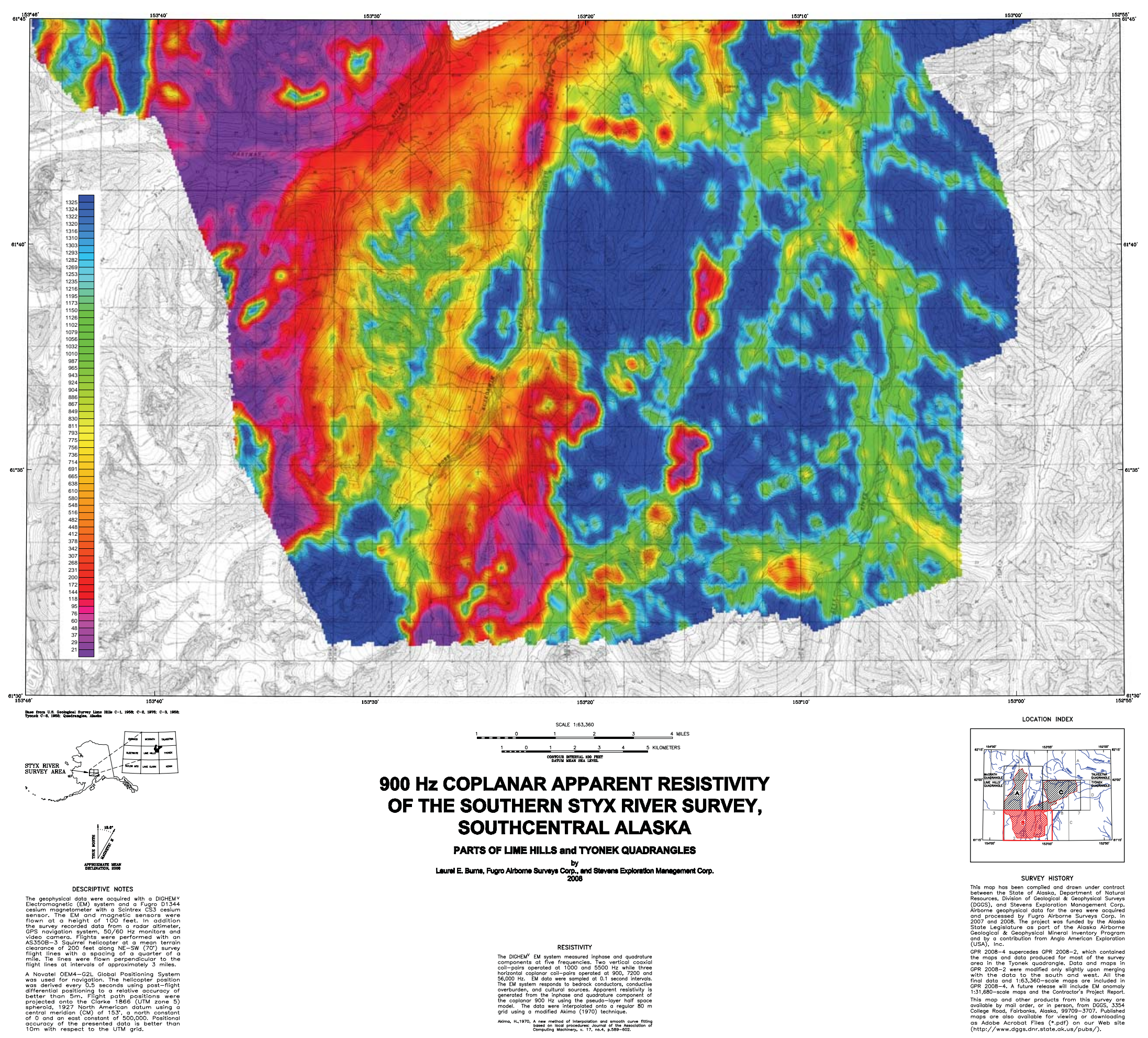




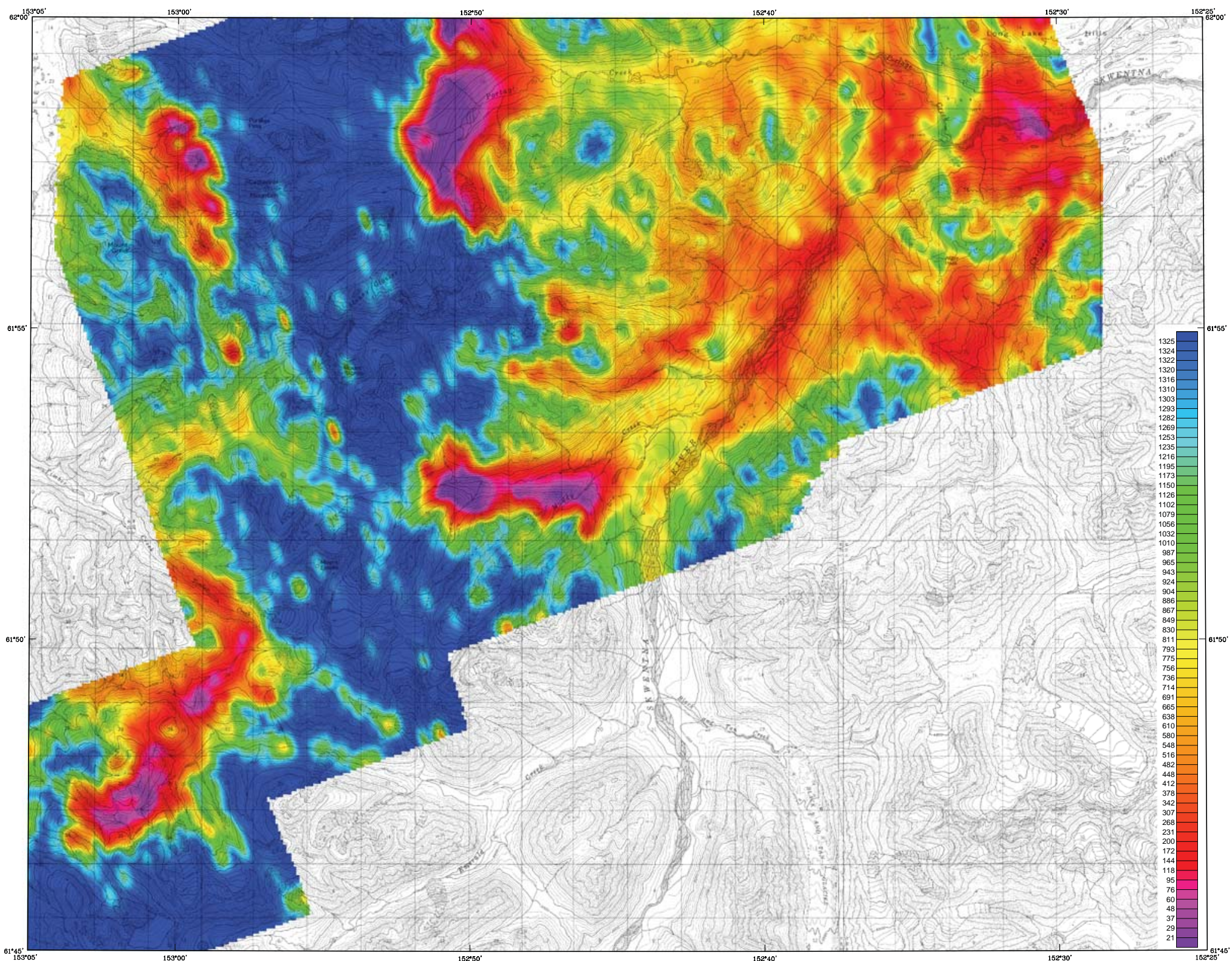

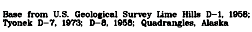

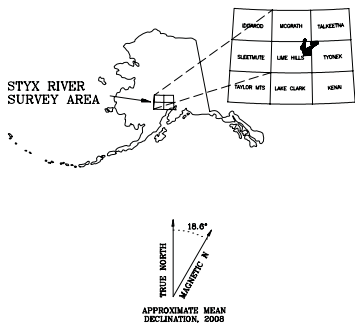

$900 \mathrm{~Hz}$ COPLANAR APPARENT RESISTIVITY
OF THE EASTERN STYX RIVER SURVEY, SOUTHCENTRAL ALASKA

PARTS OF LIME HILLS and TYONEK QUADRANGLES
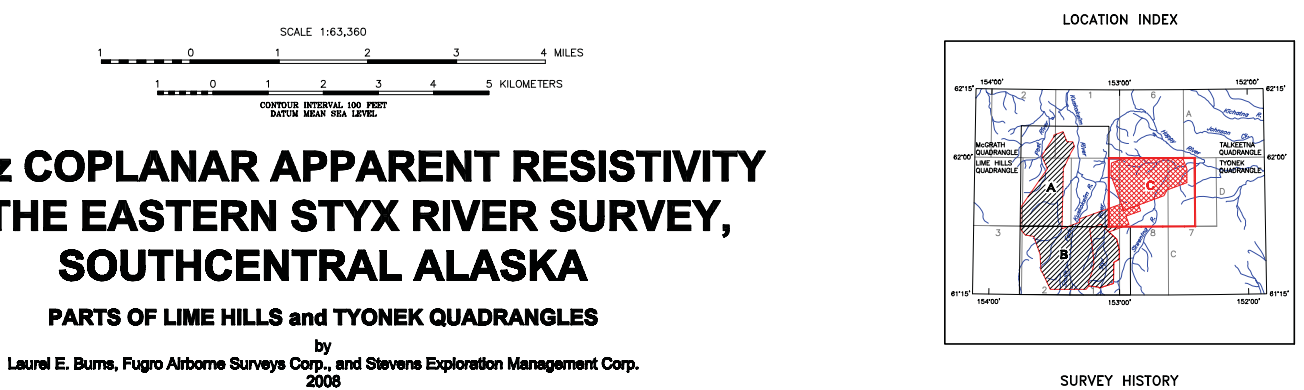

SURVEY HISTORY

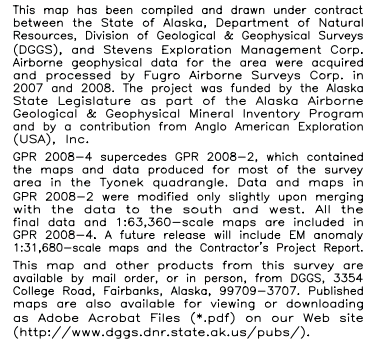




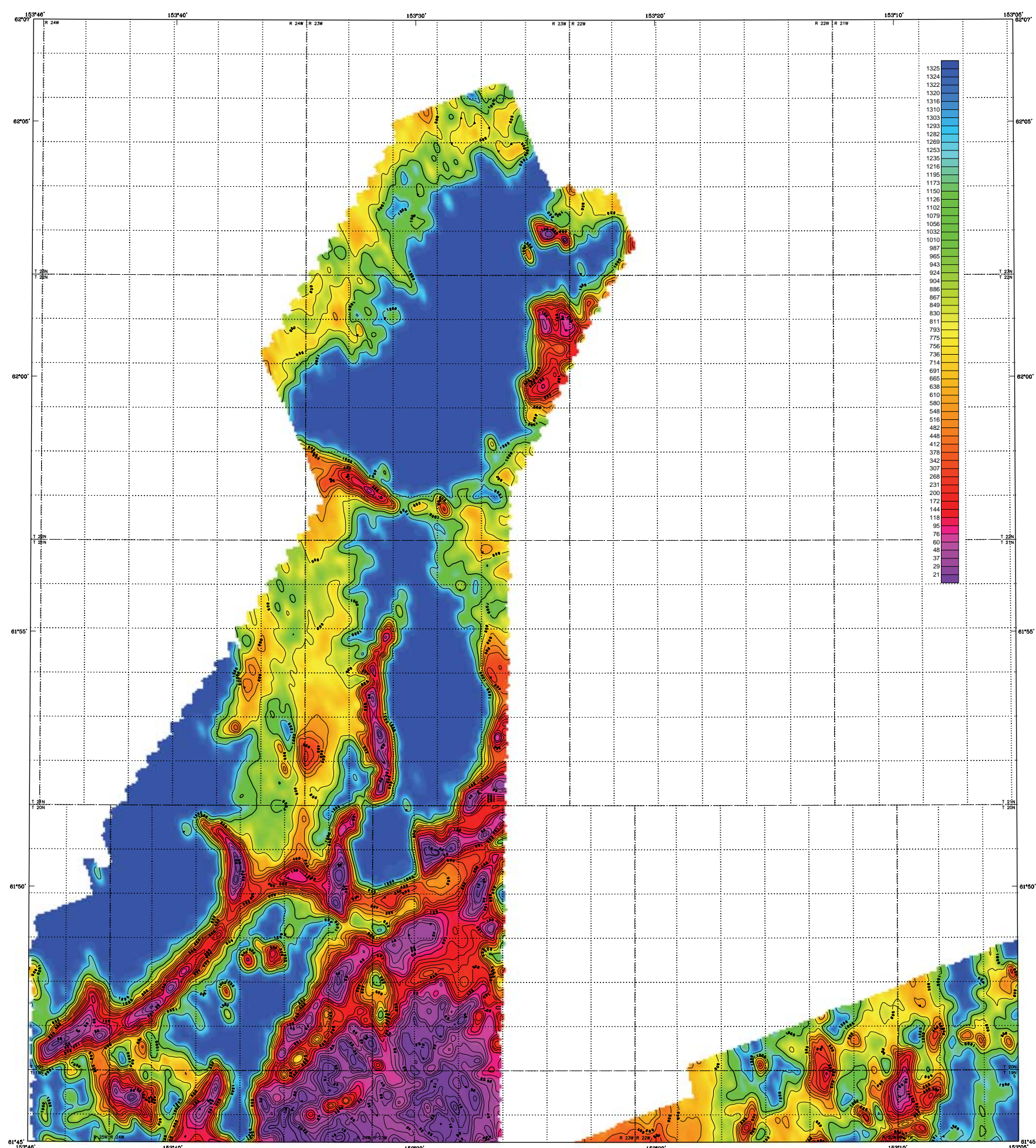

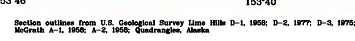
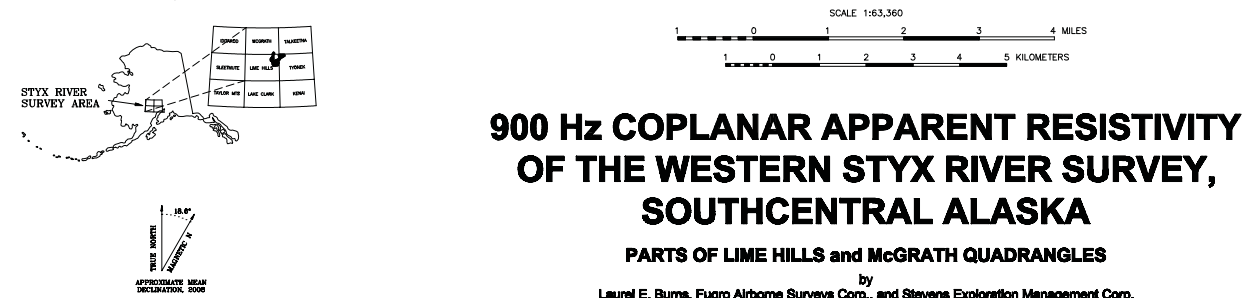

PARTS OF LIME HILLS and McGRATH QUADRANGLES

DESCRPTIVE NOTES
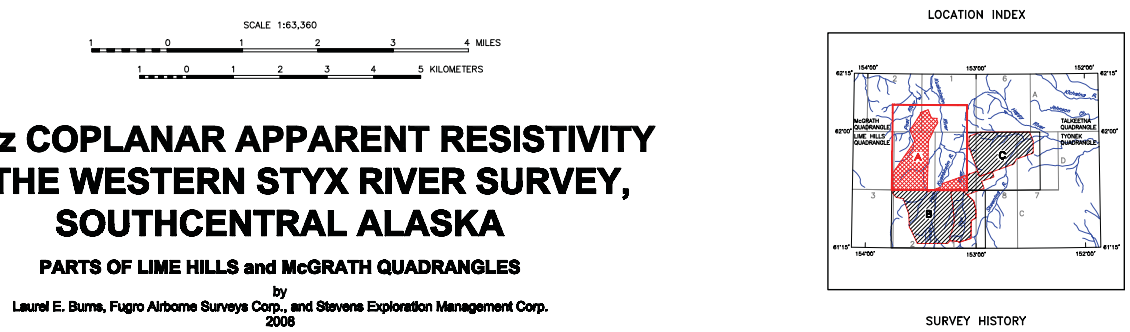

SURVEY HISTORY
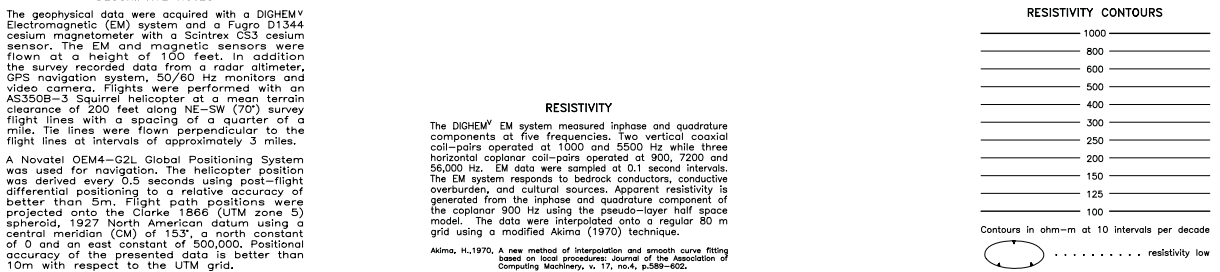

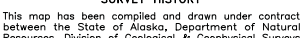
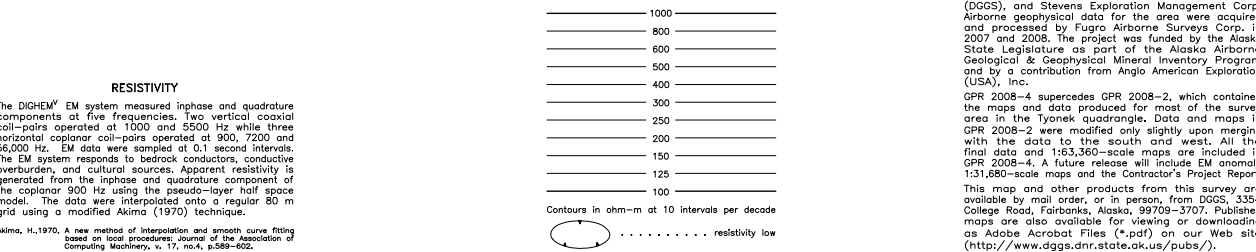

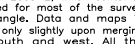




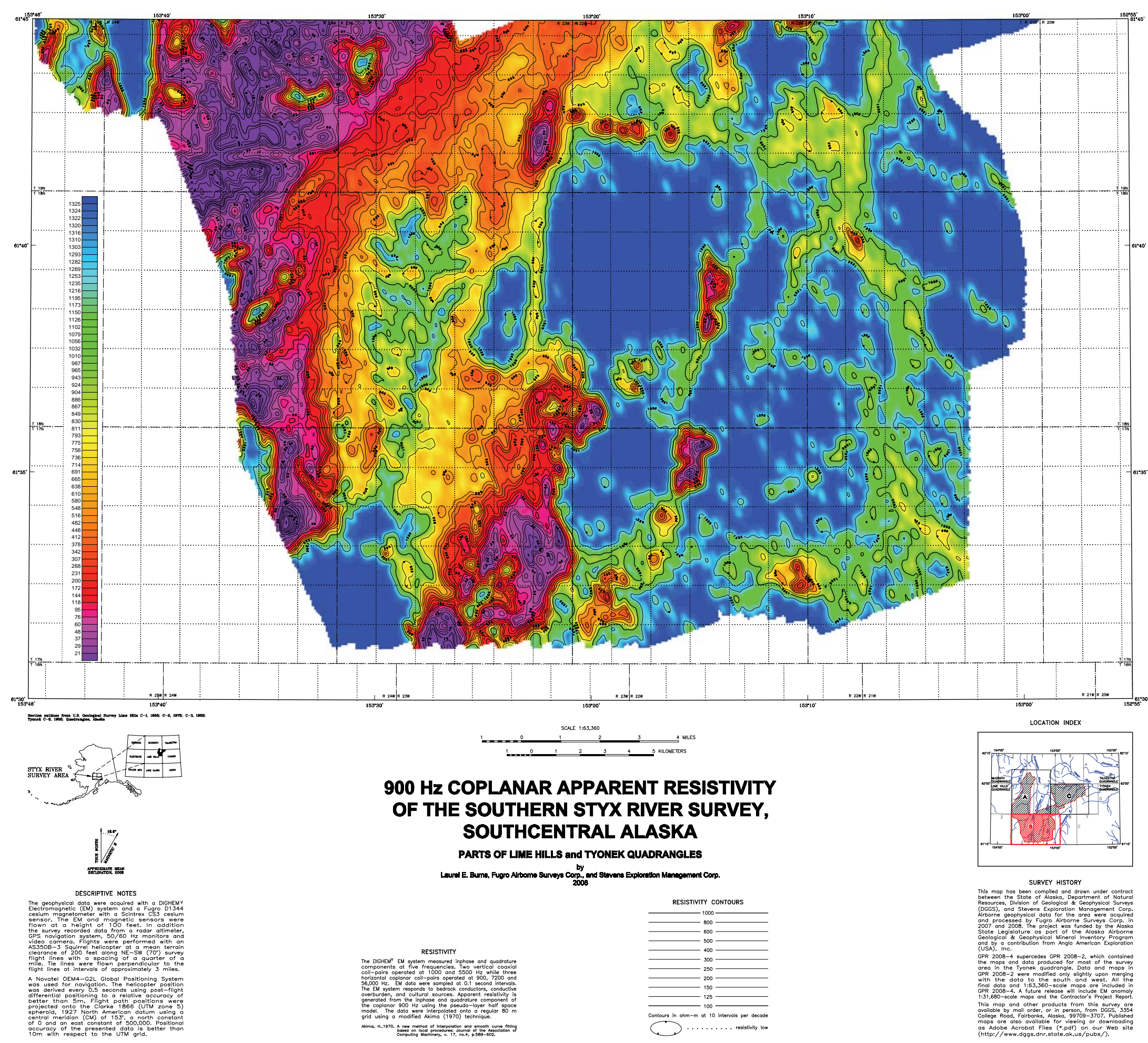




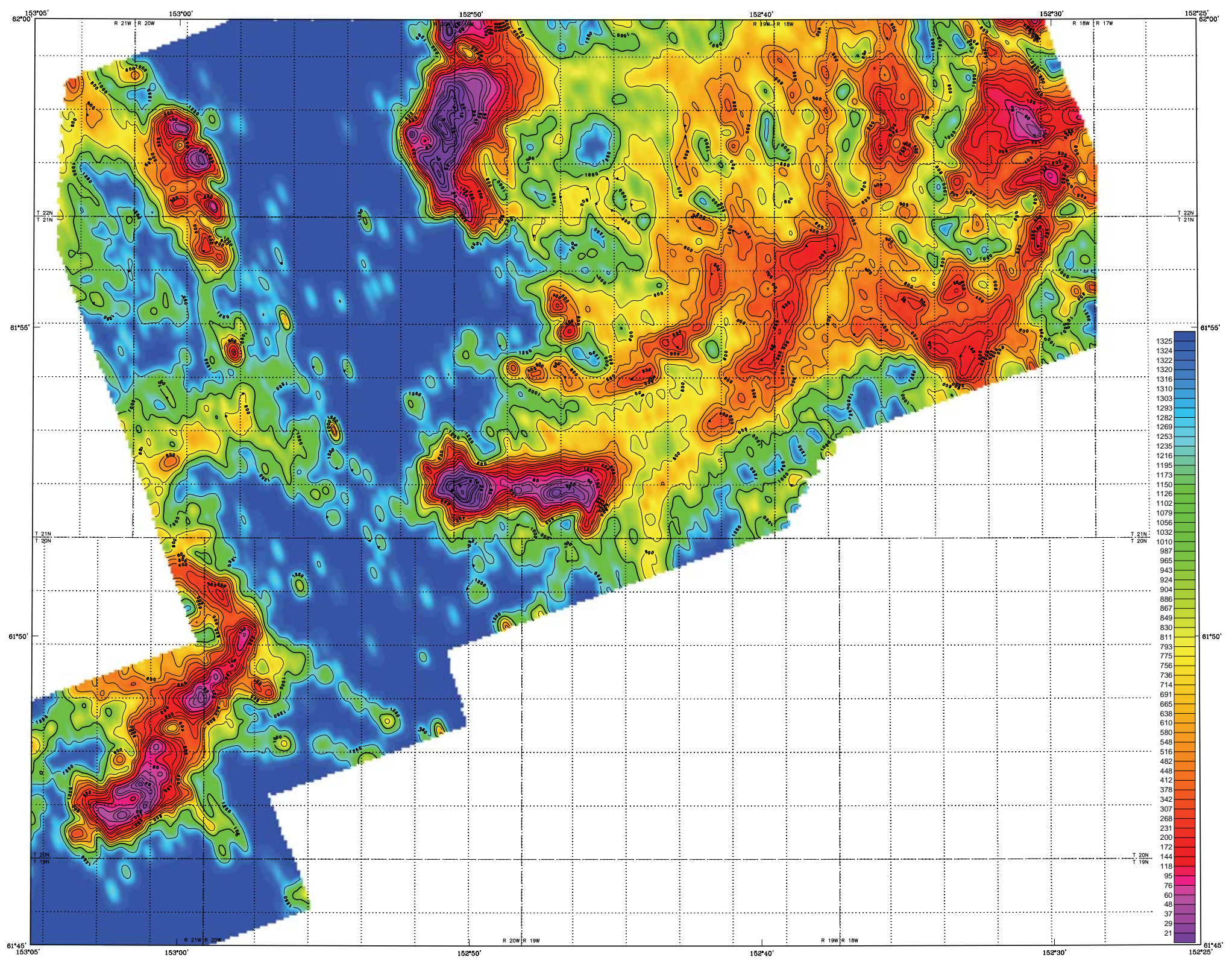

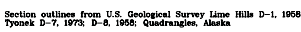

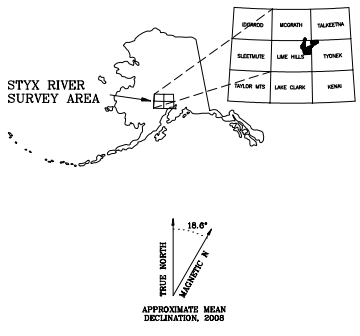

\section{$900 \mathrm{~Hz}$ COPLANAR APPARENT RESISTIVITY OF THE EASTERN STYX RIVER SURVEY,} SOUTHCENTRAL ALASKA

PARTS OF LIME HILLS and TYONEK QUADRANGLES

Laurel E. Bums, Fugro Aibome Surveys Corp., and Stevens Exploration Management Corp.

DESCRIPTIVE NOTES

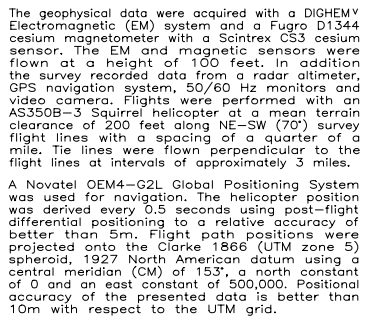

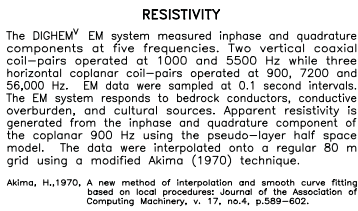

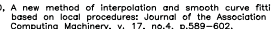

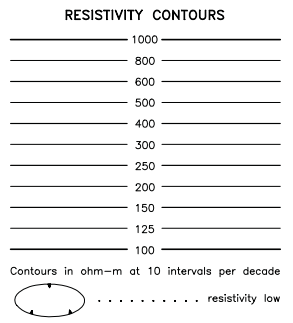

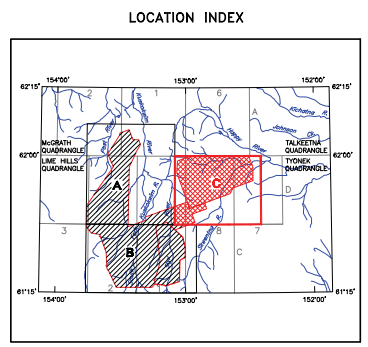

SURVEY HISTORY

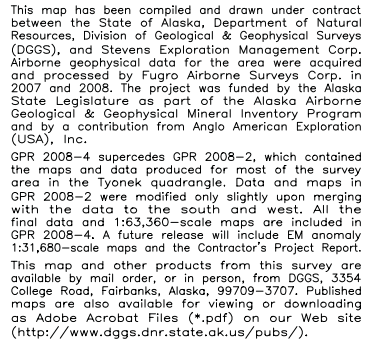




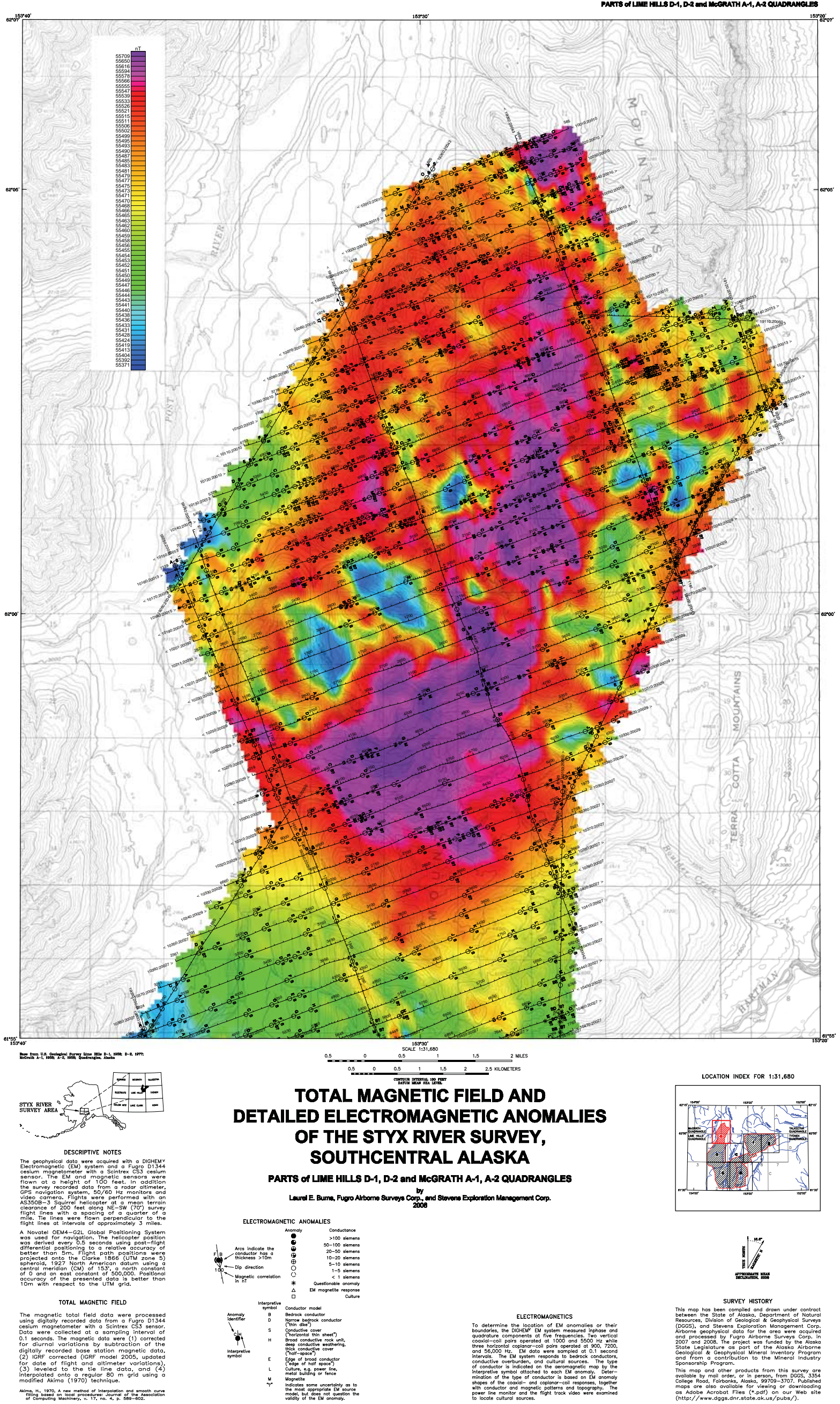




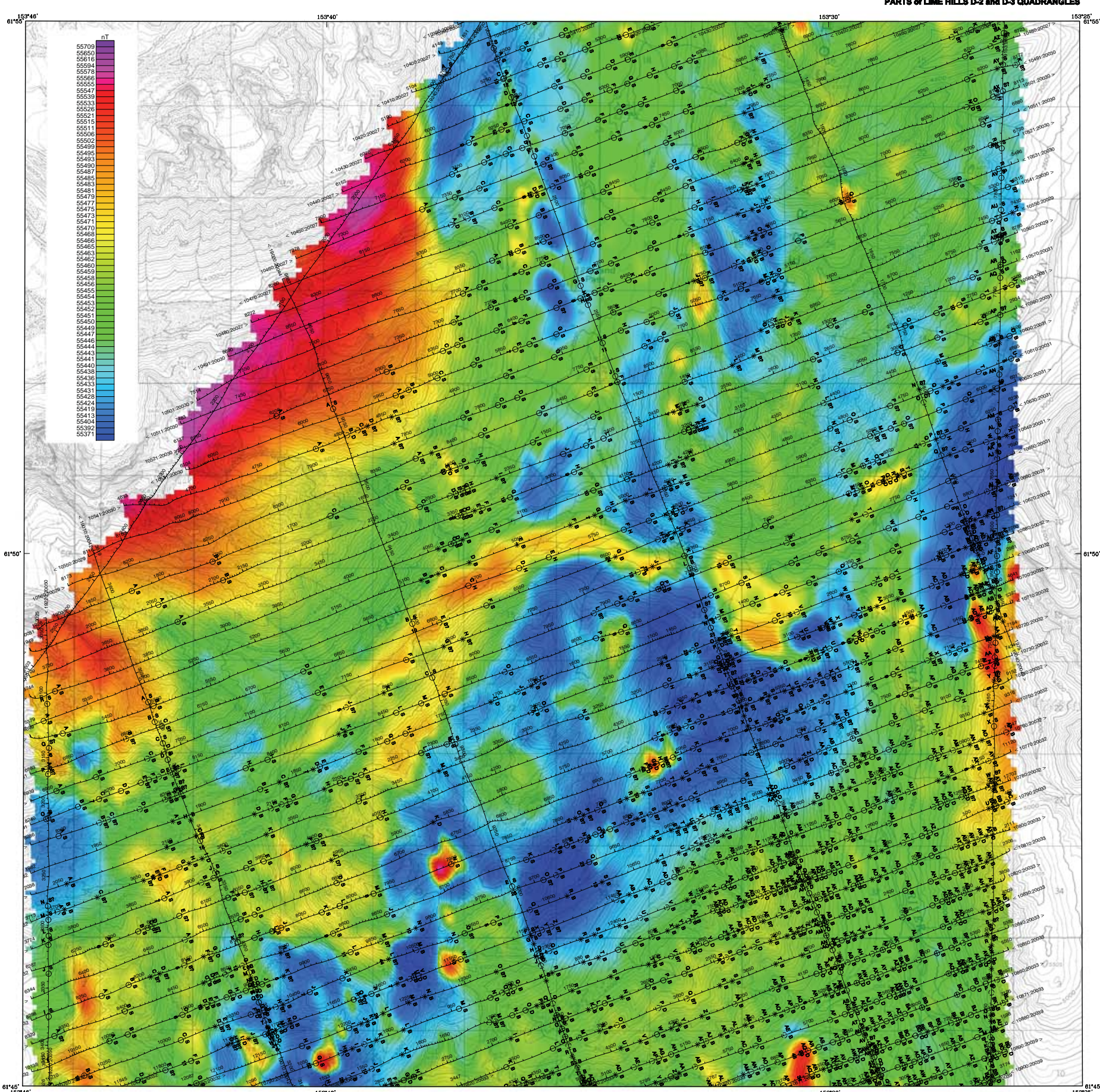

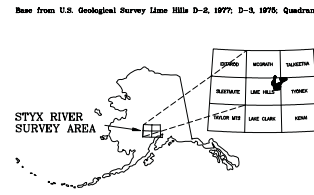

DESCRIPTIVE NOTES

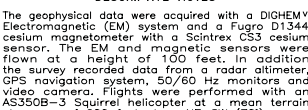

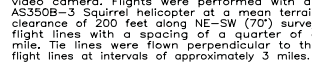

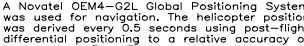

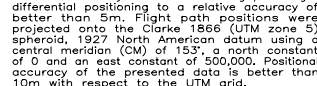

TOTAL MAGNETIC FIELD

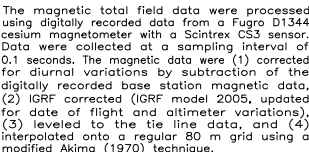

TOTAL MAGNETIC FIELD AND DETAILED ELECTROMAGNETIC ANOMALIES OF THE STYX RIVER SURVEY, SOUTHCENTRAL ALASKA

PARTS of LIME HILLS D-2 and D-3 QUADRANGLES Laurel E. Bums, Fugro Arbome Surveys Corp., and Stevens Exploration Management Corp.

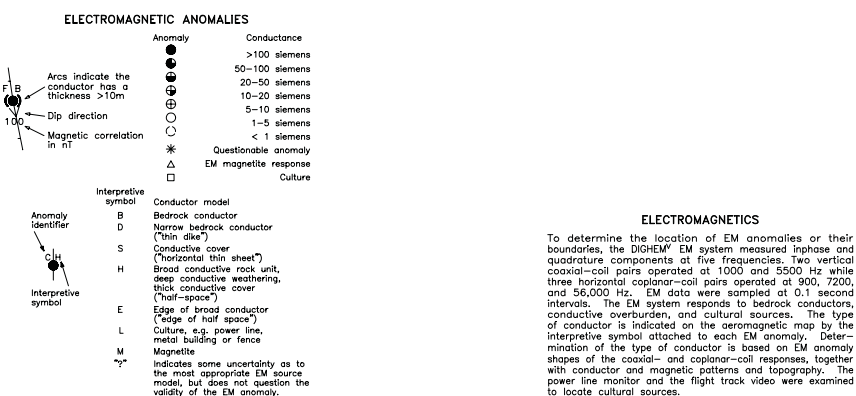

LOCATION INDEX FOR $1: 31,680$
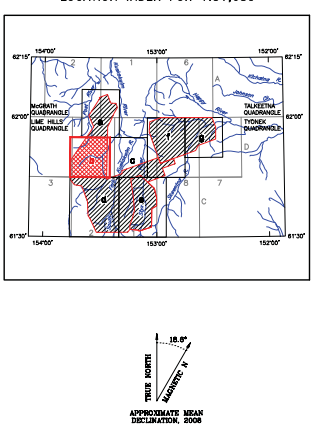

SURVEY HISTORY

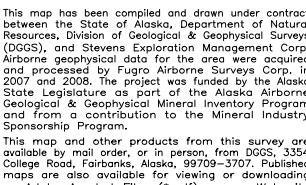




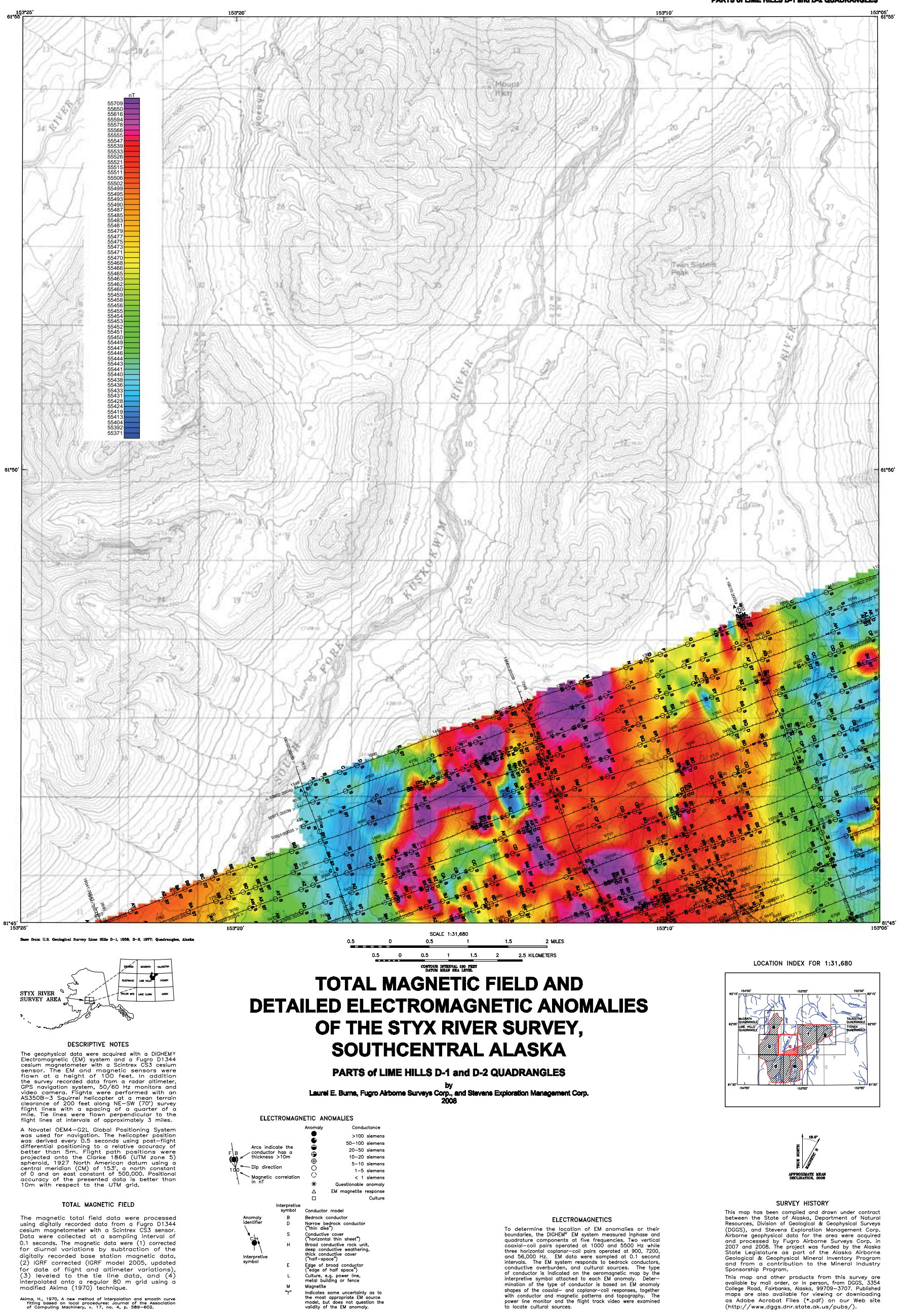




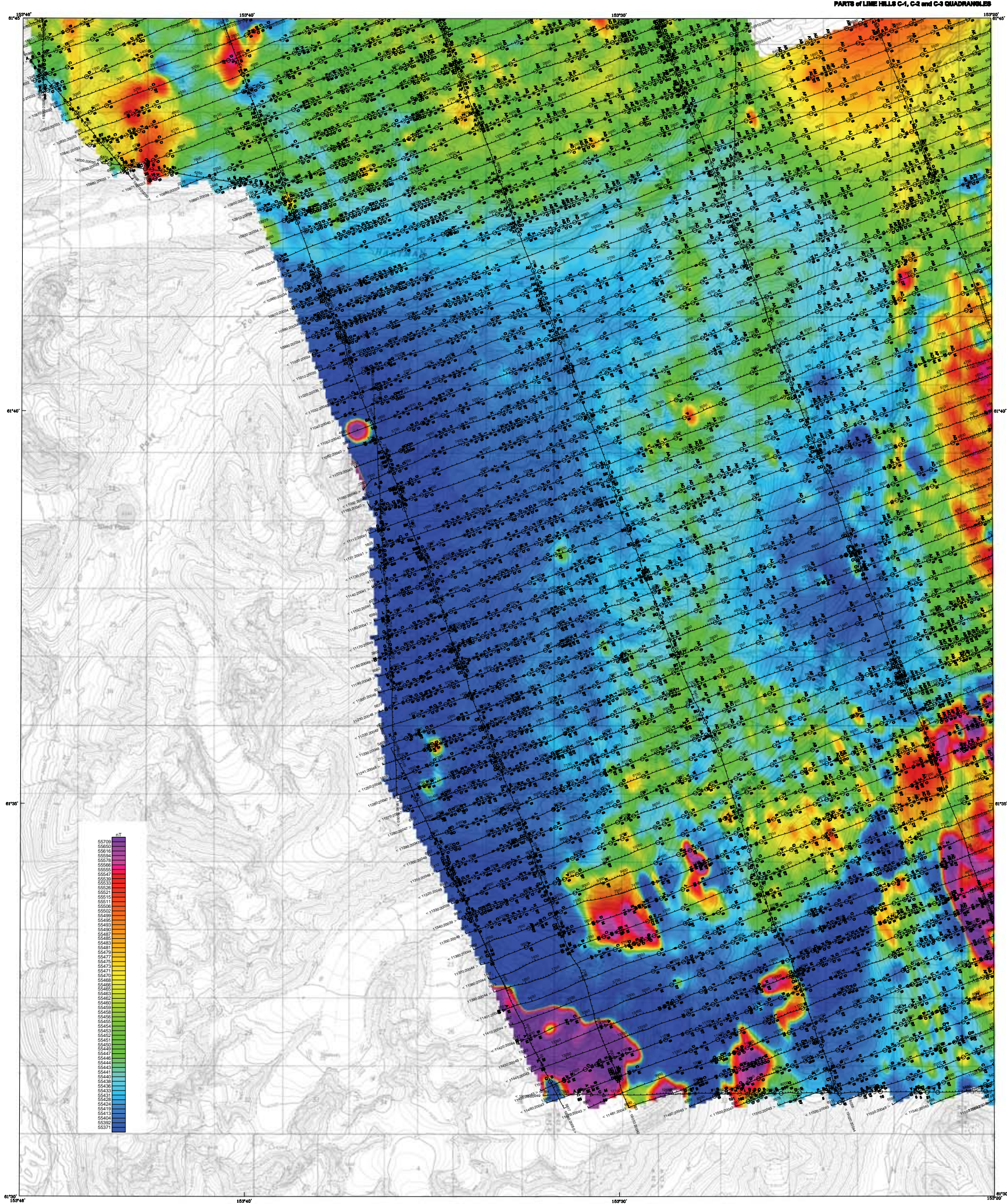

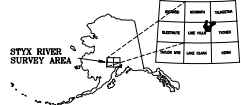

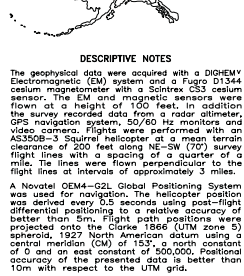

TOTAL MAGKETC FE

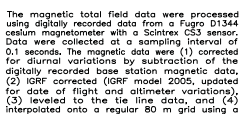

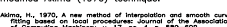

TOTAL MAGNETIC FIELD AND

DETAILED ELECTROMAGNETIC ANOMALIES

OF THE STYX RIVER SURVEY, SOUTHCENTRAL ALASKA

PARTS of LIME HILLS C-1, C-2 and C-3 QUADRANGLES

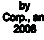
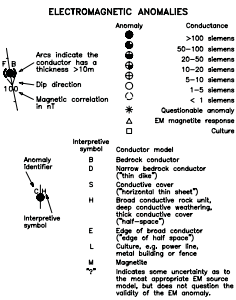

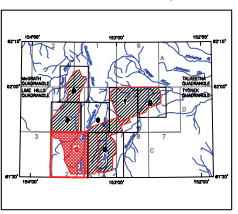

$1 / \%$
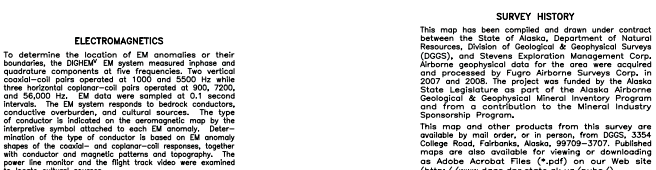


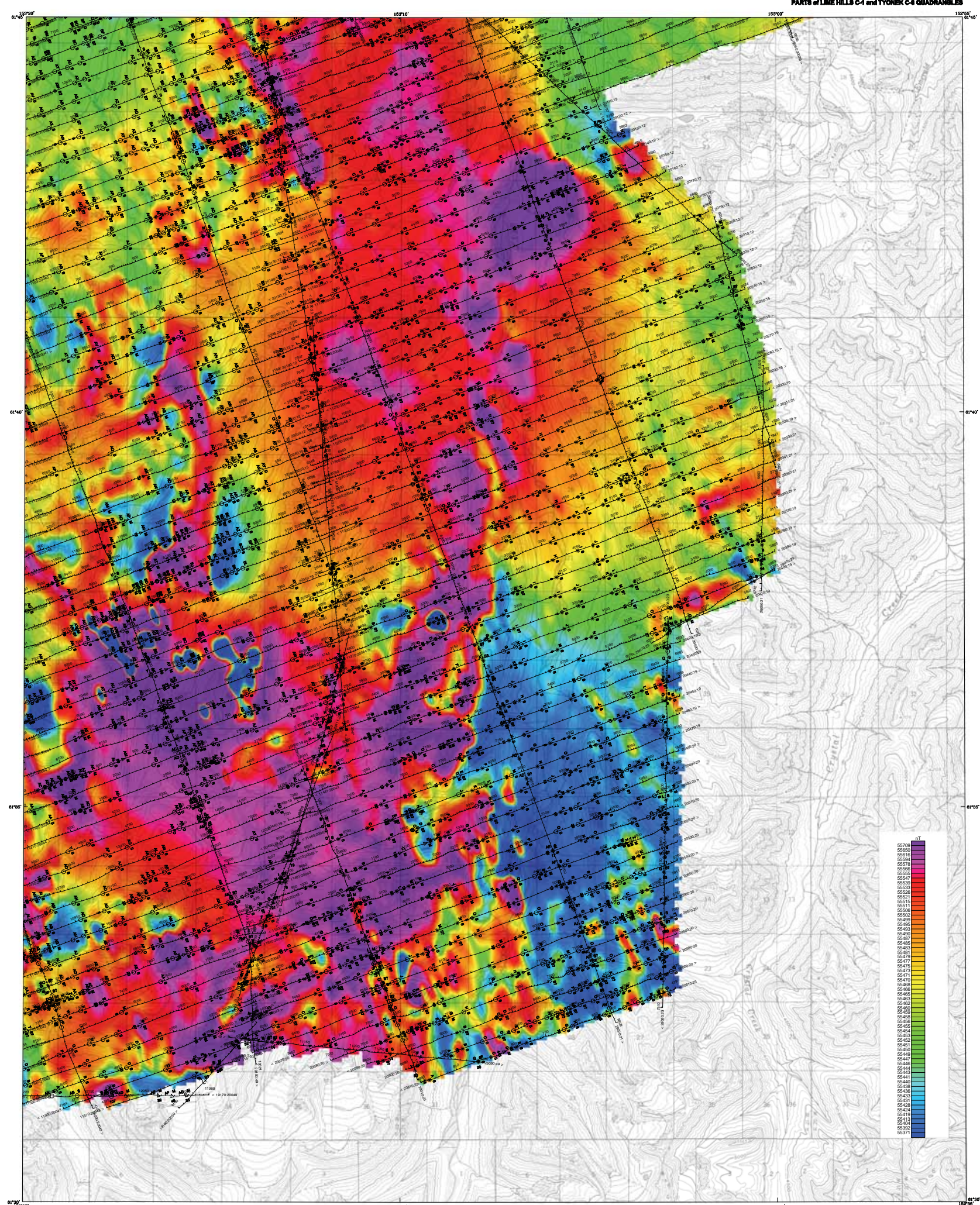

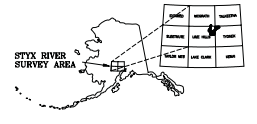

DESCRPTTVE NOEES

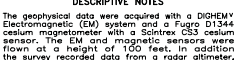

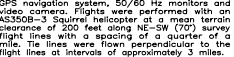

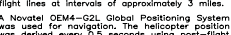

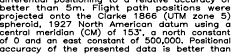

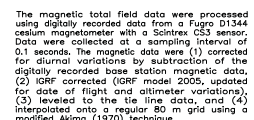

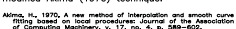

TOTAL MAGNETIC FIELD AND

DETAILED ELECTROMAGNETIC ANOMALIES

OF THE STYX RIVER SURVEY,

SOUTHCENTRAL ALASKA

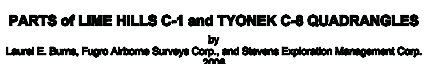

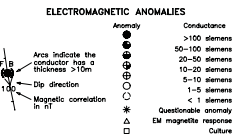

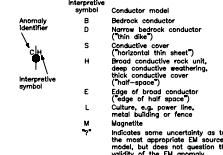

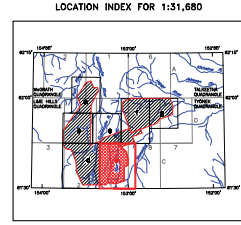

.
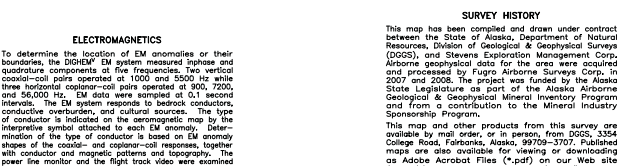


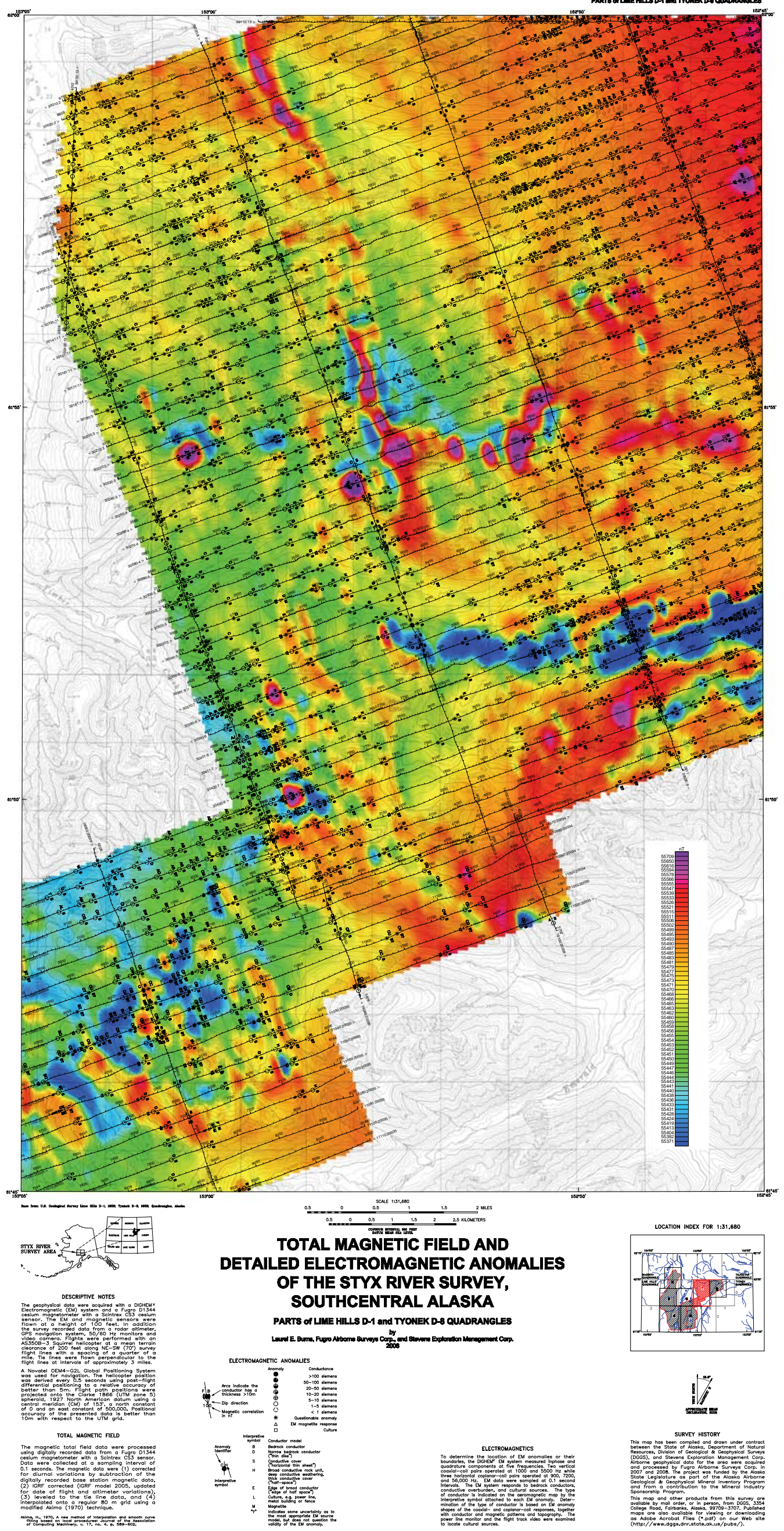




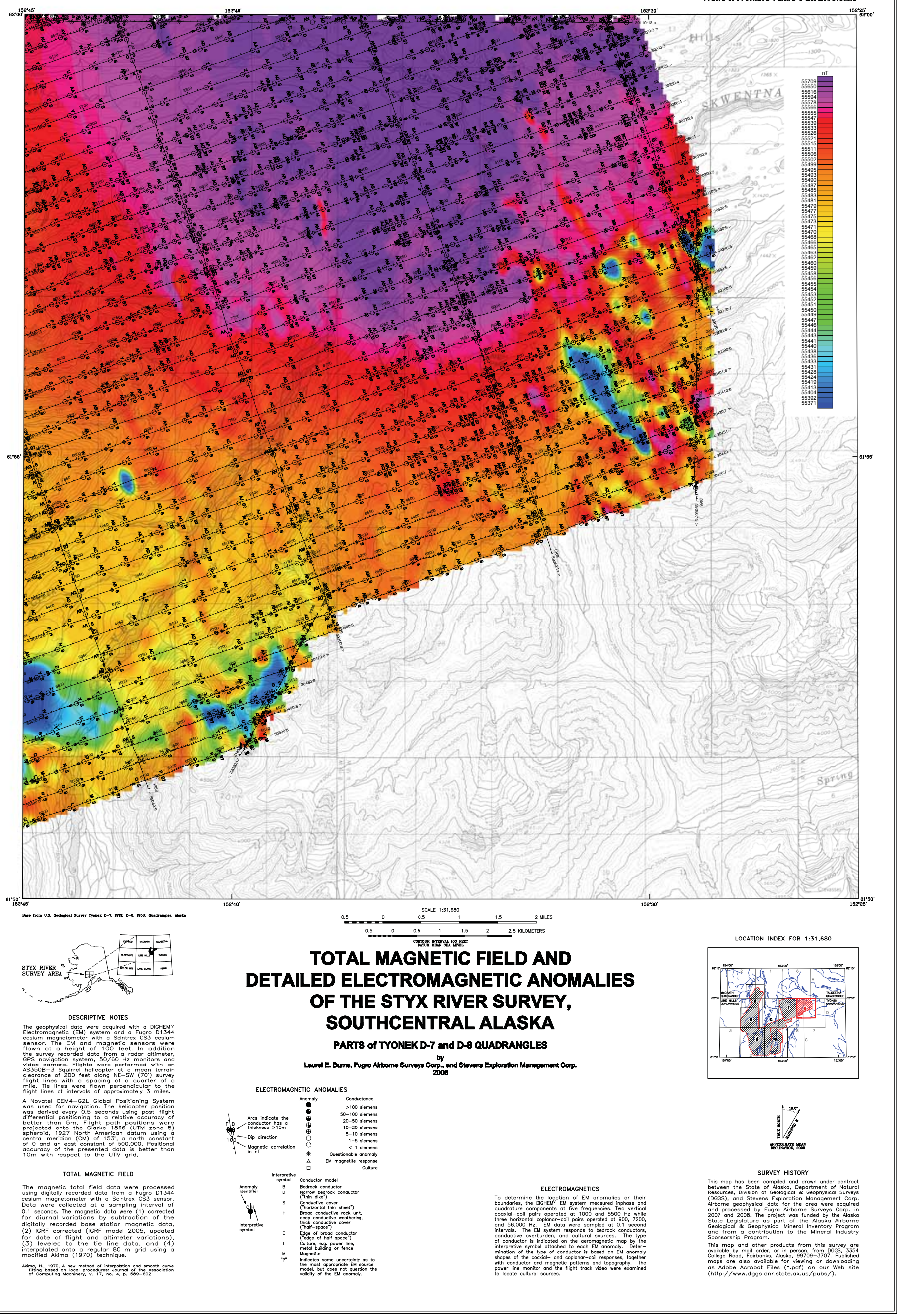




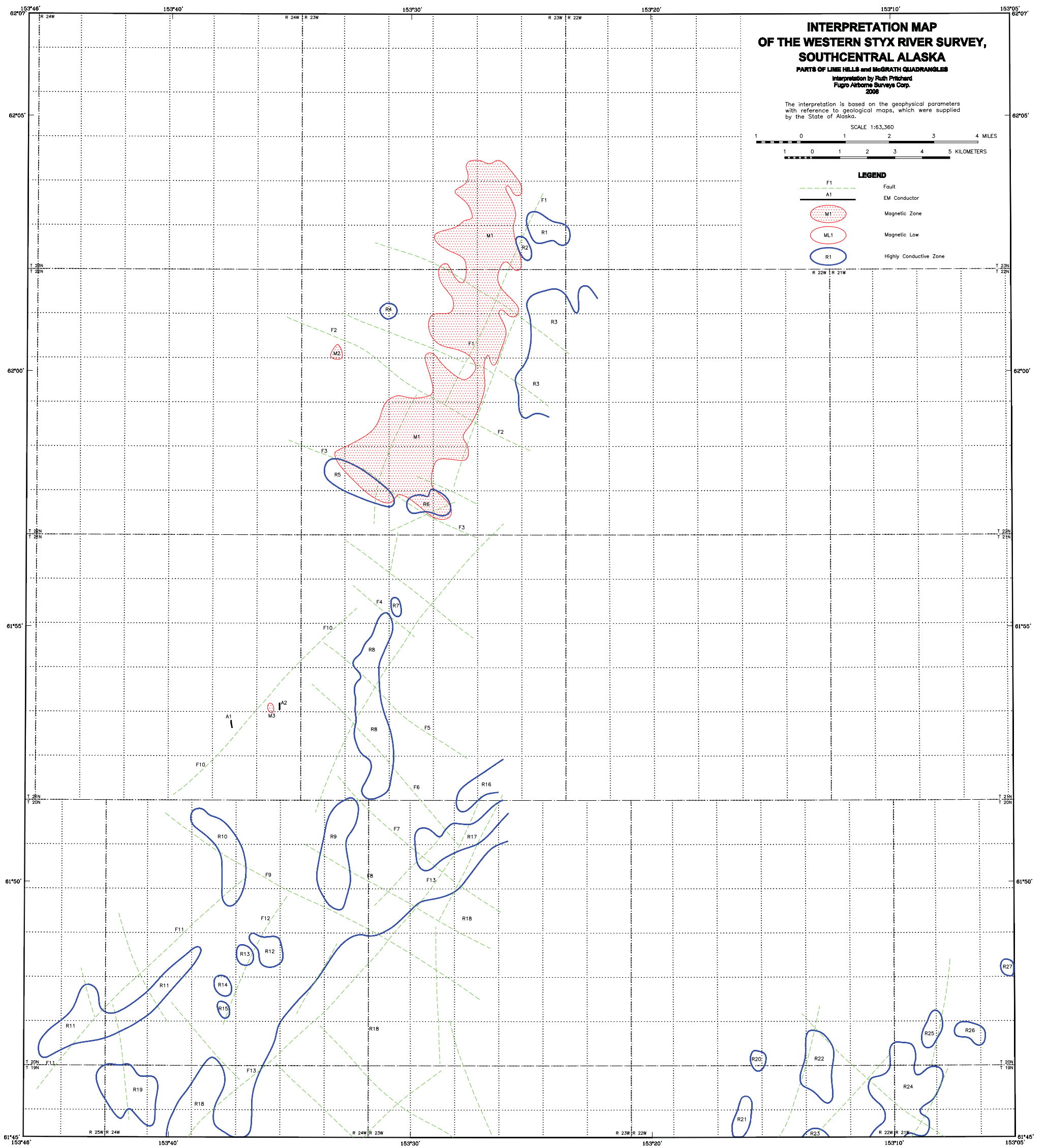




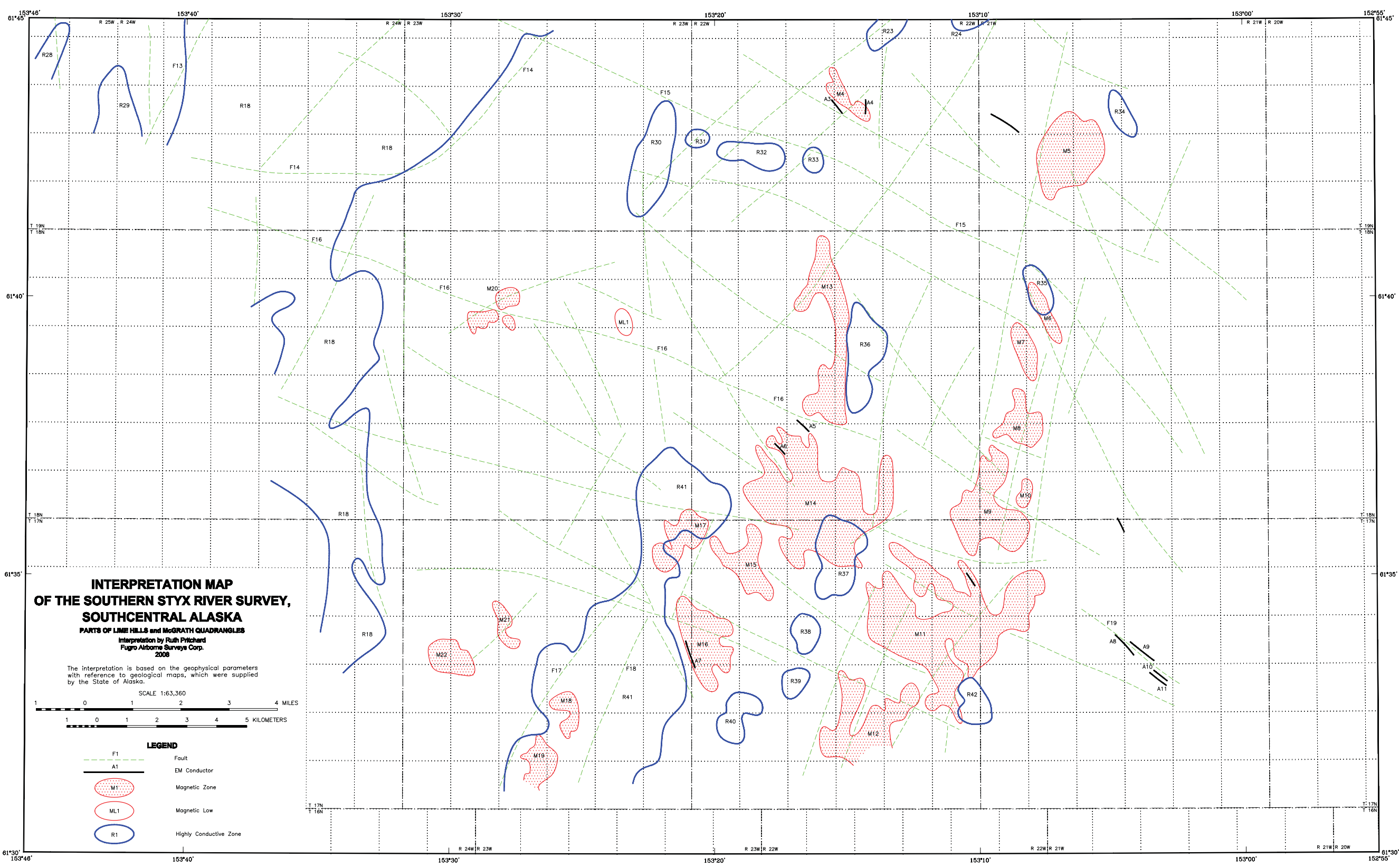


ALASKA DIVISION OF GEOLOGICAL \& GEOPHYSICAL SURVEYS

GEOPHYSICAL REPORT 2008-5-2C

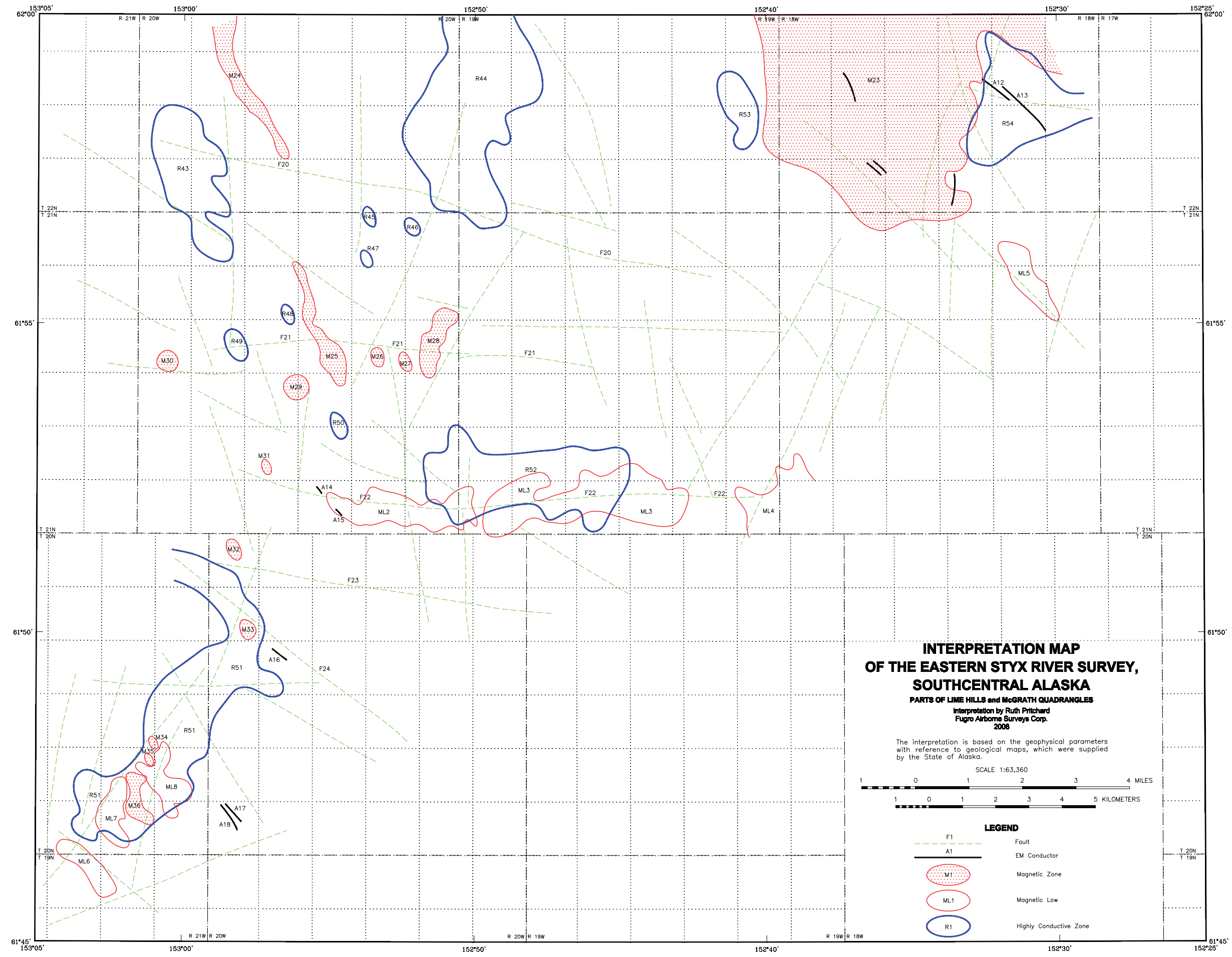

